\title{
DOEIET/27108--TI
}

\section{A RESERVOIR ASSESSMENT OF THE GEYSERS GEOTHERMAL FIELD}

Richard P. Thomas -subsurface Geology Rodger H. Chapman -Geophysics Herman Dykstra -Reservoir Assessment

\section{A. D. STOCKTON - Principal Investigator}

DOE/ET/27108--T1

DE82 011700
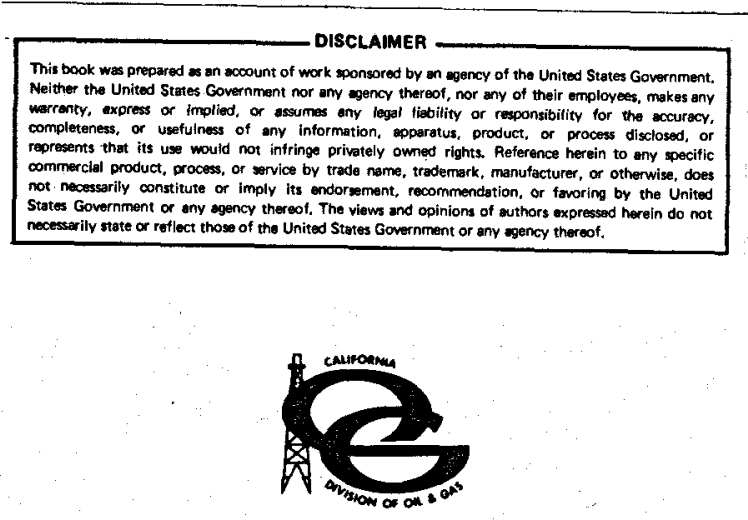

SACRAMENTO

1981 


\section{DISCLAIMER}

This report was prepared as an account of work sponsored by an agency of the United States Government. Neither the United States Government nor any agency Thereof, nor any of their employees, makes any warranty, express or implied, or assumes any legal liability or responsibility for the accuracy, completeness, or usefulness of any information, apparatus, product, or process disclosed, or represents that its use would not infringe privately owned rights. Reference herein to any specific commercial product, process, or service by trade name, trademark, manufacturer, or otherwise does not necessarily constitute or imply its endorsement, recommendation, or favoring by the United States Government or any agency thereof. The views and opinions of authors expressed herein do not necessarily state or reflect those of the United States Government or any agency thereof. 


\section{DISCLAIMER}

Portions of this document may be illegible in electronic image products. Images are produced from the best available original document. 
( 


\section{CONTENTS}

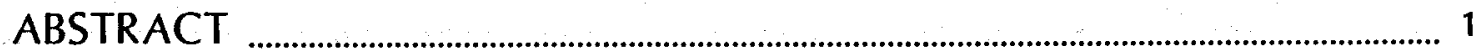

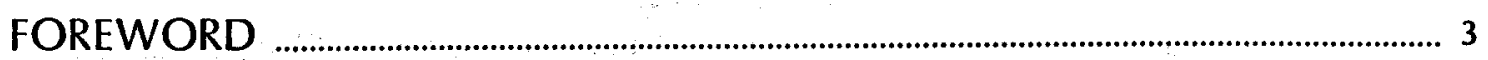

I. THE GEYSERS GEOTHERMAL FIELD, A. D. Stockton ......................................... 5

II. SUBSURFACE GEOLOGY, Richard P. Thomas .................................................. 9

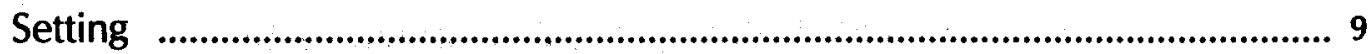

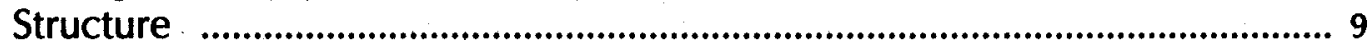

Geometry of the Reservoir Top ...............................................................................14

Hydrothermal Fluid Flow Regime .....................................................................17

III. GEOPHYSICS, Rodger H. Chapman …................................................................. 21

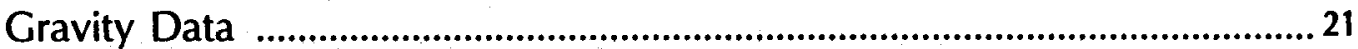

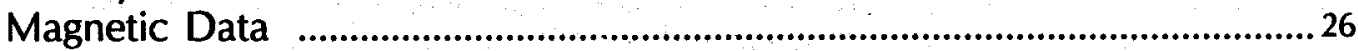

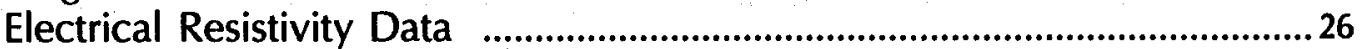

Audio-Magnetotelluric Data .............................................................................. 28

Temperature Measurements and Heat Flow ……………….............................. 31

Seismological Investigations .................................................................................... 32

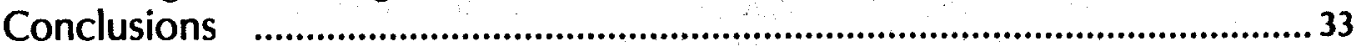

IV. RESERVOIR ASSESSMENT, Herman Dykstra ................................................... 35

Previous Studies …….......................................................................................35

Reservoir Description ....................................................................................36

Production and Injection Characteristics ......................................................42

Reservoir Analysis ............................................................................................ 47

V. DRILLING TECHNOLOGY, A. D. Stockton …………….................................... 51

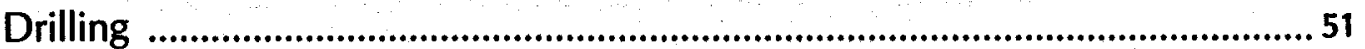

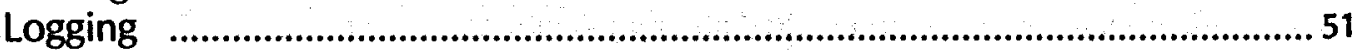

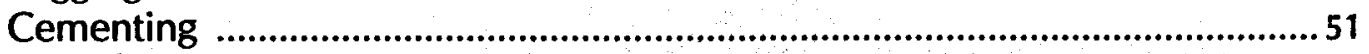

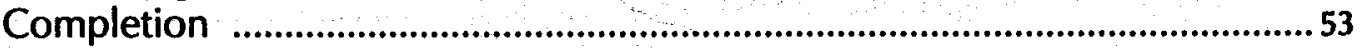

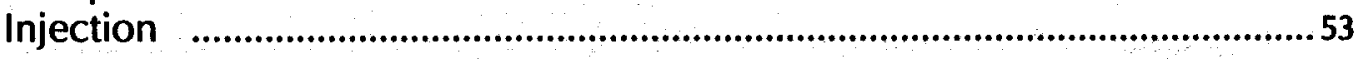

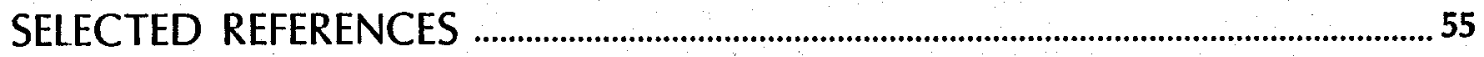




\section{ILLUSTRATIONS}

\section{FIGURES}

Figure 1A. Location of The Geysers Geothermal field, Lake and Sonoma Counties, California.................................. 6

Figure 1B. Location of The Geysers Geothermal field, Lake and Sonoma Counties, California ................................ 7

Figure 2. Generalized geologic map of The Geysers Geothermal field and vicinity ...............................................10

Figure 3. Isopach map of the large, serpentinite body (MUM) in the central area of The Geysers

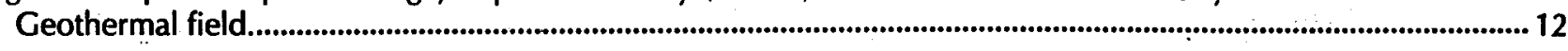

Figure 4. Idealized map of first reported steam entries at The Geysers Geothermal field. .......................................15

Figure 5. Three first steam entry anomalies at The Geysers Geothermal field................................................................16

Figure 6. Schematicized cross section of The Geysers Geothermal field, showing the inferred relationship of geologic structure to hydrothermal fluid flow.

Figure 7. Residual gravity (at $2.67 \mathrm{~g} / \mathrm{cc}$ ) in the vicinity of The Geysers Geothermal field, after removal of the field from a sphere buried at $13.5 \mathrm{~km}$.

Figure 8. Gravity profile $A-A^{\prime}$ showing generalized geology and residual and calculated gravity anomalies in the vicinity of The Geysers Geothermal field.

Figure 9. Generalized geology and residual gravity in The Geysers Geothermal field. .25

Figure 10. Ground magnetic traverse, Jimtown-Geysers-Clear Lake. .27

Figure 11. Geoelectrical cross section compiled from VES interpretations......................................................................29

Figure 12. Pseudosection, audio-magnetotelluric data, west-east component...............................................................30

Figure 13. Pseudosection, audio-magnetotelluric data, north-south component. ............................................................ 31

Figure 14. Static pressure and temperature surveys, Well A. ......................................................................................37

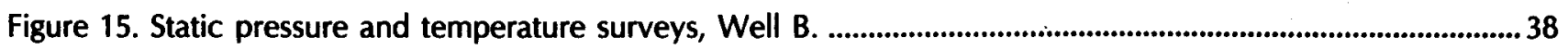

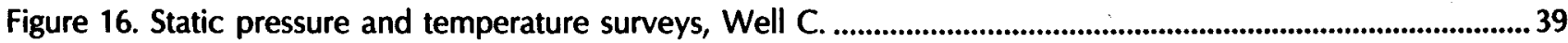

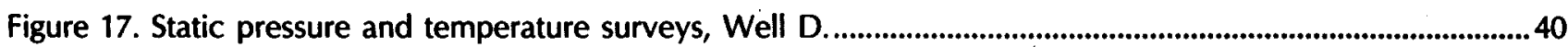

Figure 18. Steam production rate vs. time, wells "DX State" 3 and 4, The Geysers Geothermal field.

Figure 19. Steam production rate vs. time, well "GDC" 85-12 The Geysers Geothermal field. .43

Figure 20. Steam production rate vs. time, wells "Happy Jack" 5 and 6, The Geysers Geothermal field. 
Figure 21. Steam production rate vs. time, well "Lakoma Fame State" 6, The Geysers Geothermal field.

Figure 22. Steam production rate vs. time, wells "Ottoboni State" 2 and 8, The Geysers Geothermal field.

Figure 23. Steam production rate vs. time, wells "Sulphur Bank" 7 and 17, The Geysers Geothermal field.

Figure 24. Steam production rate vs. time, well "Thermal" 10, The Geysers Geothermal field 45

Figure 25. Monthly production rate of The Geysers Geothermal field. 46

Figure 26. Average decline curve for a steam well at The Geysers Geothermal field. 48

Figure 27. Generalized, cementing, casing and drilling program. . .52

\section{TABLES}

Table 1. Power plants in The Geysers Geothermal field 8

Table 2. Big Geysers area shallow zone cumulative production and reservoir pressure, 19571967, The Geysers Geothermal field.. .35

Table 3. Noncondensible gases in steam from wells at The Geysers power plant. .36

Table 4. Analysis of noncondensible gas from an Aminoil well, The Geysers Geothermal field 36

Table 5. Wells A(Run 1), B, and D pressures and saturation temperatures at a depth of $1524 \mathrm{~m}$ (5,000 feet). 41

Table 6. Calculation of heat in place above $93.3^{\circ} \mathrm{C}\left(200^{\circ} \mathrm{F}\right)$, The Geysers Geothermal field. . .41

Table 7. Steam production, in billion pounds per month, The Geysers Geothermal field. . .46

Table 8. Yearly production, in million pounds, The Geysers Geothermal field. . .47

Table 9. Monthly water injection, in million barrels per month, The Geysers Geothermal field . .47

\section{PLATES}

Plate 1. The Geysers Geothermal field. In pocket

Plate II. Contour map on top of main graywacke, The Geysers Geothermal field. In pocket

Plate III. Cross sections A-A', B-B', The Geysers Geothermal field. In pocket

Plate IV. Contour map of first reported steam entry, The Geysers Geothermal field. In pocket

Plate V. Quaternary(?) fault map, The Geysers Geothermal field In pocket

Plate VI. Residual gravity map of The Geysers area. In pocket

Plate VII. Residual gravity map of The Geysers area after the major negative anomaly was removed. In pocket

Plate VIII. Aeromagnetic map of the Clear Lake area, Lake, Sonoma, Napa, and Mendocino Counties, California. In pocket

Plate IX. Composite apparent resistivity map of The Geysers Geothermal area. In pocket 


\section{PHOTOS}

Photo 1. Power plant Units 3 and 4, The Geysers Geothermal field................................................................... 5

Photo 2. Pervasively fractured graywacke, The Geysers Geothermal field...............................................................14

Photo 3. Fractured graywacke showing open fractures, some with quartz-lined vugs...........................................14

Photo 4. Well Union "DX State 4596" 59, being drilled with air at The Geysers Geothermal field .............................51 


\section{ABSTRACT}

Big Sulphur Creek fault zone, in The Geysers Geothermal field, may be part of a deep-seated, wrench-style fault system. Hydrothermal fluid in the field reservoir may rise through conduits beneath the five main anomalies associated with the Big Sulphur Creek wrench trend. Upon cresting, the fluid may descend through an extensive, moderately dipping, fracture network. Condensed steam at the steep reservoir flanks drains back to the hot water table. These flanks are defined roughly by marginallyproducing geothermal wells. Field extensions are expected to be on the southeast and northwest.

Some geophysical anomalies (electrical resistivity and audio-magnetotelluric) evidently are caused by the hot water geothermal field or zones of altered rocks; others (gravity, P-wave delays, and possibly electrical resistivity) probably represent the underlying heat source, a possible magma chamber; and others (microearthquake activity) may be related to the steam reservoir.

A large negative gravity anomaly and a few low-resistivity anomalies suggest areas generally favorable for the presence of steam zones, but these anomalies apparently do not directly indicate the known steam reservoir.
Monitoring gravity and geodetic changes with time and mapping microearthquake activity are methods that show promise for determining reservoir size, possible recharge, production lifetime, and other characteristics of the known steam field. Seismic reflection data may contribute to the efficient exploitation of the field by identifying fracture zones that serve as conduits for the steam.

At the current generating capacity of $930 \mathrm{MWe}$, the estimated life of The Geysers Geothermal field reservoir is 129 years. The estimated reservoir life is 60 years for the anticipated maximum generating capacity of $2,000 \mathrm{MWe}$ as of 1990.

Wells at The Geysers are drilled with conventional drilling fluid (mud) until the top of the steam reservoir is reached; then, they are drilled with air. Usually, mud, temperature, caliper, dual induction, and cement bond logs are run on the wells. Casing in the well is cemented at the top of the steam reservoir. Sometimes, a small amount of steam is allowed to escape from a well before it is connected to a power plant. This prevents steam from condensing in the well bore and quenching the well. 


\section{FOREWORD}

In 1979, a contract to undertake a reservoir investigation of The Geysers Geothermal field was signed by the California Division of Oil and Gas (CDOG) and the U.S. Department of Energy (DOE) (contract No. DE-FG10380ET27108). Under the agreement, most of the project funding was from the DOE, with the remainder from the CDOG.

The purpose of the project was to study the nature and extent of the reservoir at The Geysers Geothermal field and to publish the results of the investigation. The report is divided into three major chapters: a chapter on the subsurface geology is by Richard P. Thomas of the CDOG; one on geophysical data is by Rodger $\mathrm{H}$. Chapman of the California Division of Mines and Geology (CDMG), under subcontract No. 2-85; and one on reservoir assessment is by Herman Dykstra, reservoir engineering consultant, under subcontract No. 2-84. The introductory and drill. ing technology chapters are by A. D. Stockton, the Principal Investigator.

The authors wish to thank a reviewing committee composed of Simon Cordova, Forrest Bacon, Gerald Katz, James Campion, George Frye, Dennis McMurdie, Marshall Reed, Robert Strand, James Vantine, and the many other industry and governmental representatives who commented upon the report.

The report is edited by Susan F. Hodgson; illustrations are by Alfred Zucca, assisted by Roscoe Martin; cover and layout are by Jim Spriggs. Typing is by Shirley Russell and Irene Turner, and typesetting is by Lois Pickering. 


\section{THE GEYSERS GEOTHERMAL FIELD}

The Geysers Geothermal field is the world's largest dry steam, commercial geothermal resource. The field is in the northwesterly-trending Mayacmas Mountains, about $65 \mathrm{~km}$ (40 miles) north of Santa Rosa, in eastern Sonoma and western Lake Counties (Figs. 1A and 1B). Ground elevations at The Geysers range from $330 \mathrm{~m}$ (1,000 feet) along Big Sulphur Creek on the northwest to $1,200 \mathrm{~m}$ $(4,000$ feet) near Cobb Mountain on the east.

Grasses, wild oaks, and thistles grow throughout the area, and a chaparral of manzanita, ceanothus, bay, and scrub oak covers the ridges. Scrub oak, oak, and buckeye trees grow in the wetter areas, and pine trees and cypress are in the upland regions and stream valleys.

The climate is hot and dry from May to October (low $30^{\prime} \mathrm{s}^{\circ} \mathrm{C}$ or $\left.90^{\prime} \mathrm{s}^{\circ} \mathrm{F}\right)$, and wet and cold from November to April (winter lows of $-6^{\circ} \mathrm{C}$ or $20^{\circ} \mathrm{F}$ ). About 88 percent of the $152 \mathrm{~cm}$ (60 inches) average annual rainfall occurs between November and April. Snow falls occasionally on the highest ridges.

Development of The Geysers Geothermal field began in 1921. At that time, a well was drilled along Big Sulphur Creek in the Big Geysers area, where there are steam vents, fumaroles, and hot springs (McMillan, 1970) ${ }^{\wedge}$. By 1925 , eight wells had been drilled, the deepest to $148 \mathrm{~m}$ (487 feet). Finally, development stopped because of poor prospects for marketing energy generated from the steam. The wells were abandoned in 1969 by the present operator (Garrison, 1972).

In 1955, development recommenced when Magma Power Company obtained a lease from The Geysers Development Company and drilled "Magma" 1, the first modern well (Allen, 1975). Then, Magma Power Company joined with Thermal Power Company to drill additional wells to test the potential of The Geysers reservoir and to aid in marketing the steam. By the end of 1959, 13 wells had been drilled.

In September 1960, the first power plant (Unit 1) was installed, with a generating capacity of 12 MWe (Megawatts of electricity). Unit 1 was powered by steam from wells "Magma" 1, "Thermal" 10, and "Thermal" 11. Ex-

\footnotetext{
${ }^{A}$ Bibliographical data for references in this chapter are in The Geysers Geothermal fieid section of the list of Selected References at the end of the report.
}

perience with the plant indicated the viability of using produced steam to generate electrical power. In March of 1963, a second power plant (Unit 2), with a generating capacity of $14 \mathrm{MWe}$, was installed. By the end of 1965, the Magma-Thermal group had drilled 37 wells.

In 1966, Union Oil Company drilled "Ottoboni Federal" 1 in Section 12, north of the Big Geysers area. In 1967, Union Oil Company and the Magma-Thermal group pooled their leases to develop the area further with Union as the unit operator. By the end of 1968, the group had drilled 52 wells, and two more power plants had been installed: Unit 3 was installed in April 1967, and Unit 4 in November 1968, for a combined generating capacity of 80 MWe. In addition, Geothermal Resources International drilled two wells now operated by Thermogenics, Inc.

Drilling activity increased in 1969 in anticipation of further power plant construction activity. From 1971 through 1975 , seven power plants were built and operated, for a total field generating capacity of $630 \mathrm{MWe}$. Then, it would be almost 5 years before another plant was placed on line.

However, by September 1980, 15 power plants were operating at The Geysers, with a total installed generating capacity of $930 \mathrm{MWe}$. Steam to drive the electrical generating facilities is piped to the power plants from about 150 producing wells. An electrical generating capacity of about 2,000 MWe should be attained by 1990 .

Information about the power plants at The Geysers Geothermal field is in Table 1.

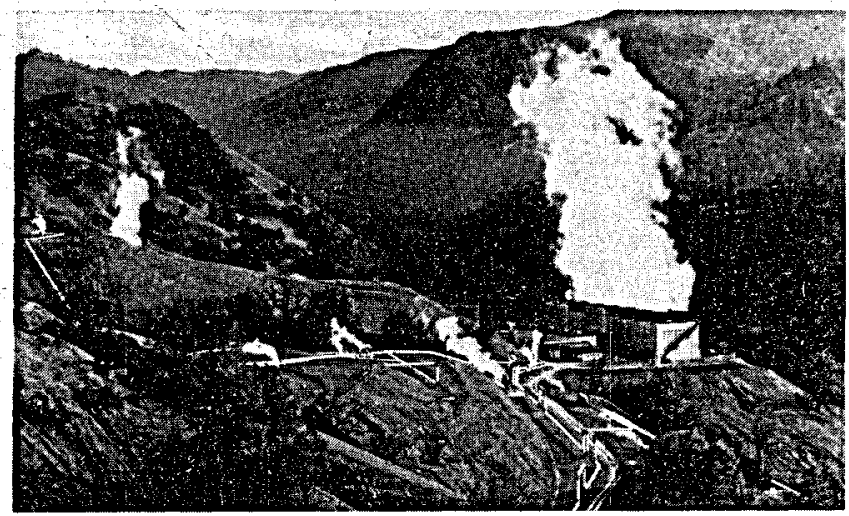

Photo 1. Power plant Units 3 and 4, The Geysers Geothermal field. 


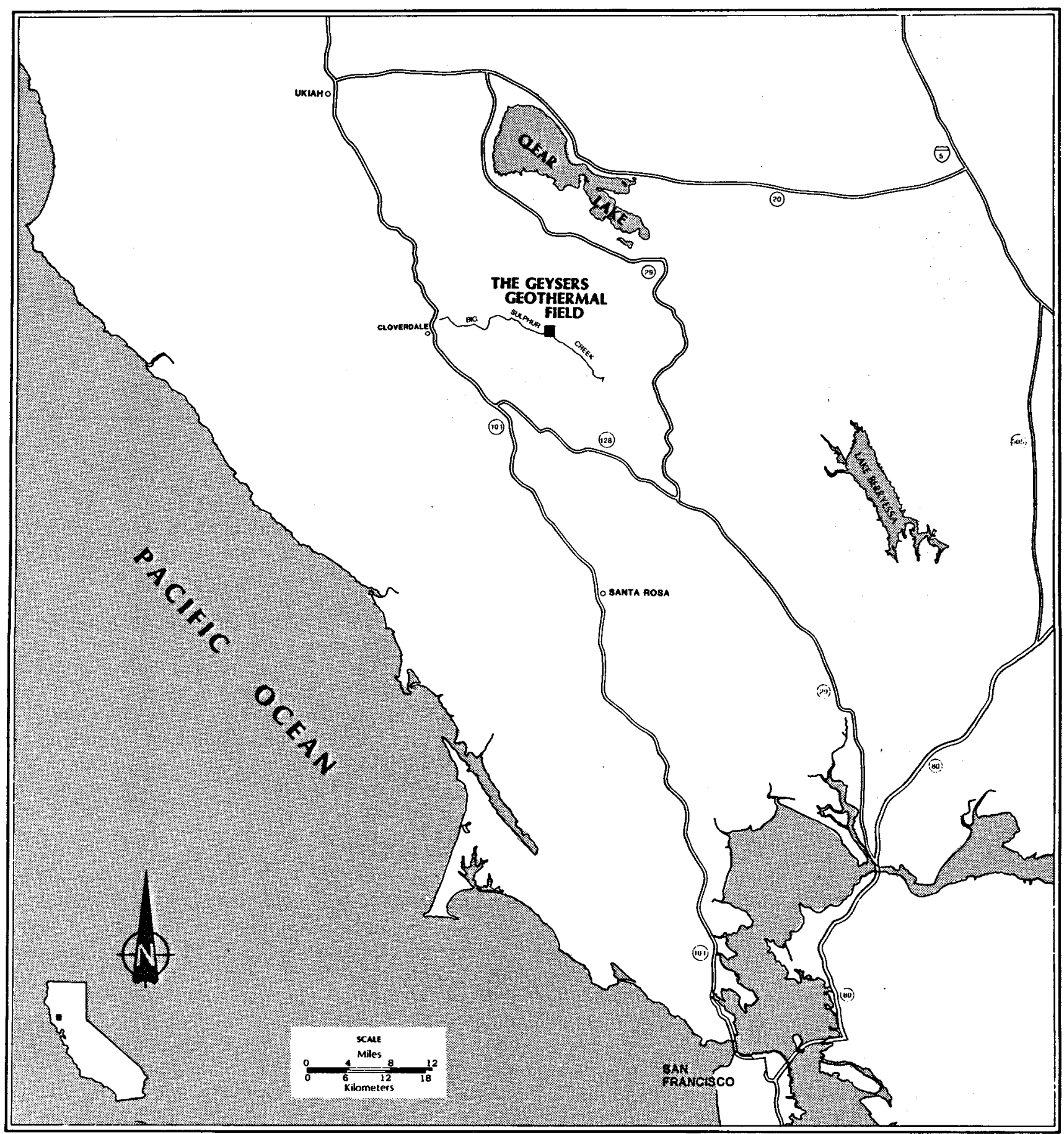

Figure 1A. Location of The Geysers Geothermal field, Lake and Sonoma Counties, California. 


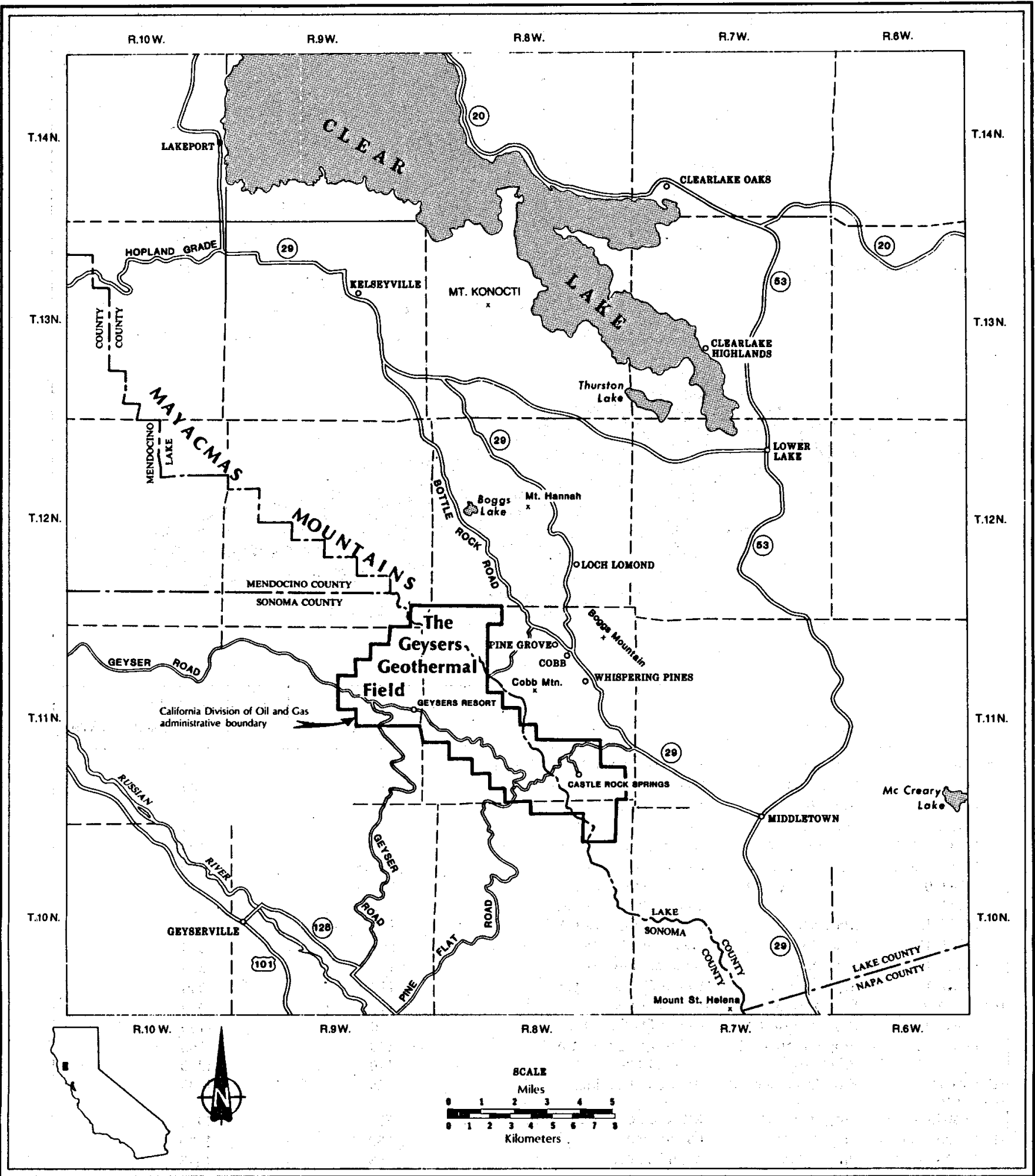

Figure 1B. Location of The Geysers Geothermal field, Lake and Sonoma Counties, California. 
Table 1. Power plants, under operation and projected for completion, The Geysers Geothermal field. Field surface depicted above the reservoir surface, represented by a computerized grid. Views are to the north from $20^{\circ}$ above the horizon. Vertical separation between the surfaces is greatly exaggerated. Computer plotting courtesy of the U.S. Geological Survey.

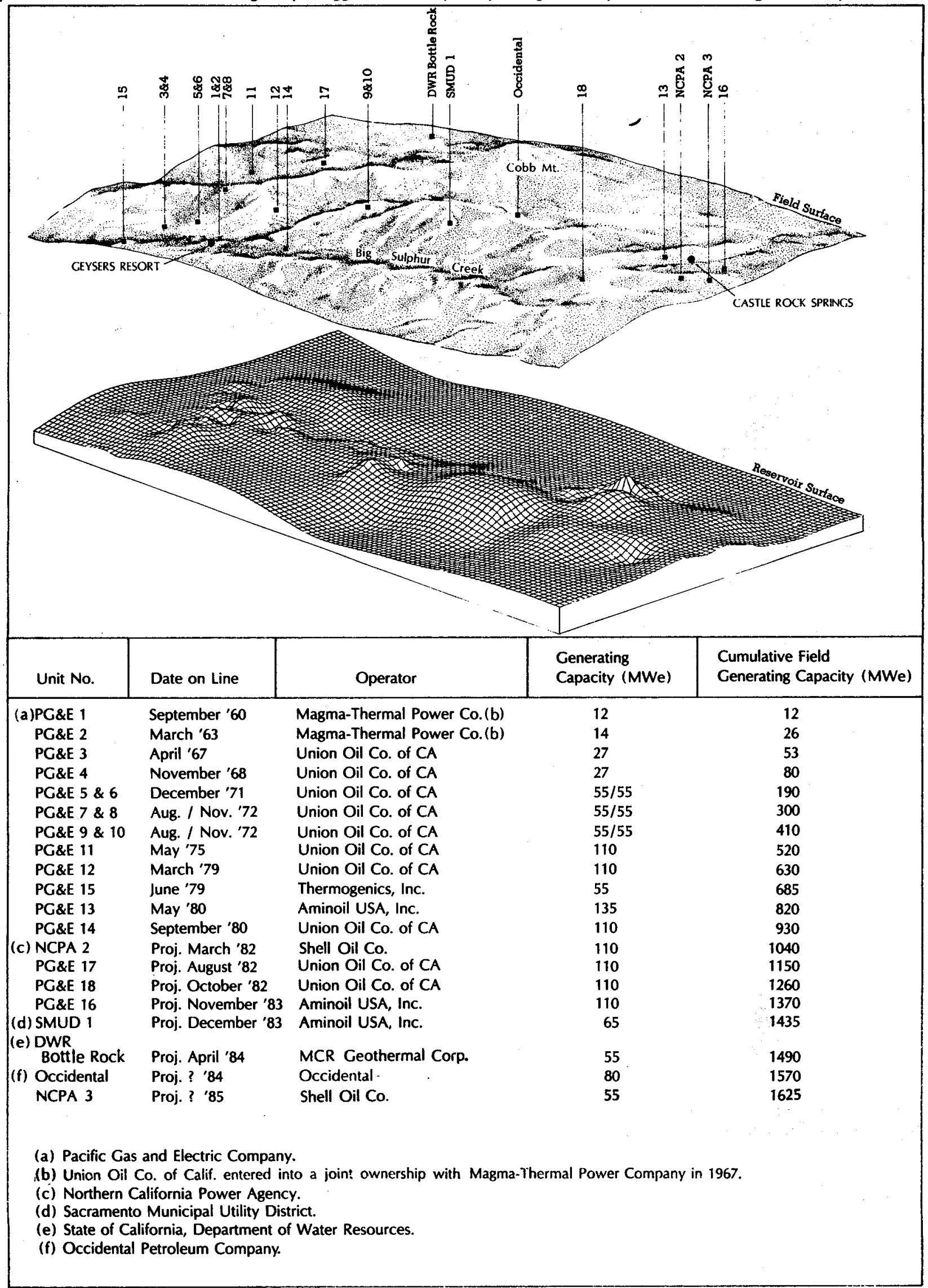




\section{SUBSURFACE GEOLOGY}

\section{SETTING}

The Geysers Geothermal field is within the northern part of the northwesterly-trending Coast Ranges province, and, according to McLaughlin (1977) northeast limb of the southeasterly-plunging Mayacama antiform. The tectonically-active, northwesterly-trending Mayacama and Collayami fault zones are major physiographic boundaries of the antiform on the southwest and northeast, respectively (McLaughlin and Stanley, 1976; Donnelly et al., 1976) (Fig. 2). The Big Sulphur Creek fault zone, along which most surface hydrothermal activity occurs, roughly bisects the antiform.

The antiform core consists predominantly of east-tonortheasterly-dipping, Late Jurassic-to- Late Cretaceous Franciscan Complex rocks. At The Geysers, the Franciscan rocks occur as highly sheared and, sometimes, chaotically mixed assemblages of metamorphosed graywacke, shale, greenstone (altered submarine volcanics), serpentinite, chert, and high-grade blueschist.

East of the geothermal field, the Coast Range thrust (Bailey et al., 1970) separates the Franciscan from rocks of the Late Jurassic-to-Late Cretaceous Great Valley sequence and the basal ophiolite complex.

North and northeast of the field, $400 \mathrm{~km}^{2}(154.4 \mathrm{sq}$. miles) of Pliocene (?)-to-Holocene Clear Lake Volcanic rocks cap the eroded rocks of the Franciscan Complex and Great Valley sequence (Hearn et al., 1976). Several small outliers of associated volcanics occur adjacent to The Geysers, the largest being a rhyolite and dacite pile capping $10 \mathrm{~km}^{2}$ ( $3.9 \mathrm{sq}$. miles) of Cobb Mountain.

\section{STRUCTURE}

\section{Structural Units}

Throughout most of the northern Coast Ranges province, Franciscan rocks of uniform metamorphic grade occur in northwesterly-trending belts. The metamorphic grade of the rock is indicated by the development of cataclasis (textural reconstitution), observed with a hand lens in graywacke, and by the progressive

\footnotetext{
^Bibliographical data for references in this chapter are under the Subsurface Geology section of the list of Selected References at the end of the report.

"In this report, the term graywacke includes rocks interbedded with argillite and argillaceous shale.
}

development of incipient, high-pressure, metamorphic minerals, including pumpellyite and lawsonite, observed under a microscope (Blake et al., 1967, McLaughlin and Stanley, 1976, McLaughlin, 1980).

McLaughlin and Stanley (1976) defined and mapped similar Franciscan rocks as three structural units (Fig. 2). The first unit, structural unit 1, occurs as a weakly-metamorphosed graywacke and contains pumpellyite. Unit 1 rocks crop out beyond The Geysers field boundaries, southwest of the Mercuryville fault zone. According to McLaughlin and Stanley (1976), unit 1 may extend beneath the geothermal field and form part of the reservoir rock.

Structural unit 2 rocks are structurally and lithologically complex, and consist, predominately, of graywacke. They have moderately developed cataclastic textures and may contain pumpellyite, with or without lawsonite. Unit 2 rocks crop out throughout most of the geothermal field.

Structural unit 3 is a similarly complex unit but contains metagraywacke with a pronounced cataclastic texture. Lawsonite (with or without pumpellyite), glaucophane, and jadeite occur in unit 3 as metamorphic minerals. Unit 3 rocks crop out in a small area of the geothermal field, south of Castle Rock Springs.

\section{Major Rock Divisions}

Throughout the productive area of The Geysers Geothermal field, a structurally and lithologically complex rock assemblage (primarily with structural unit 2 texture), referred to as the thrust assemblage, lies in thrust contact above a thick, areally extensive graywacke body, that is, in turn, intruded and underlain by an unknown volume of much younger igneous rock. Well data indicate that the thrust assemblage occurs predominately as north-to-east dipping, imbricated, tectonic slabs and wedges of graywacke, greenstone, chert, and blueschist-grade rock, occasionally intercalated with serpentinite. The underlying faulted and fractured graywacke body, including rocks of all three structural units, is referred to as the main graywacke, and is the host rock for most of the upper portion of the geothermal reservoir.

Igneous intrusives at The Geysers (commonly referred to as felsite) have been identified in well logs from an area southeast of a line drawn between the center of Sec. 9, T. $11 N .$, R. 8 W. and the Geysers Resort. Detailed analyses of cuttings from one of the wells indicate a rhyolite of 


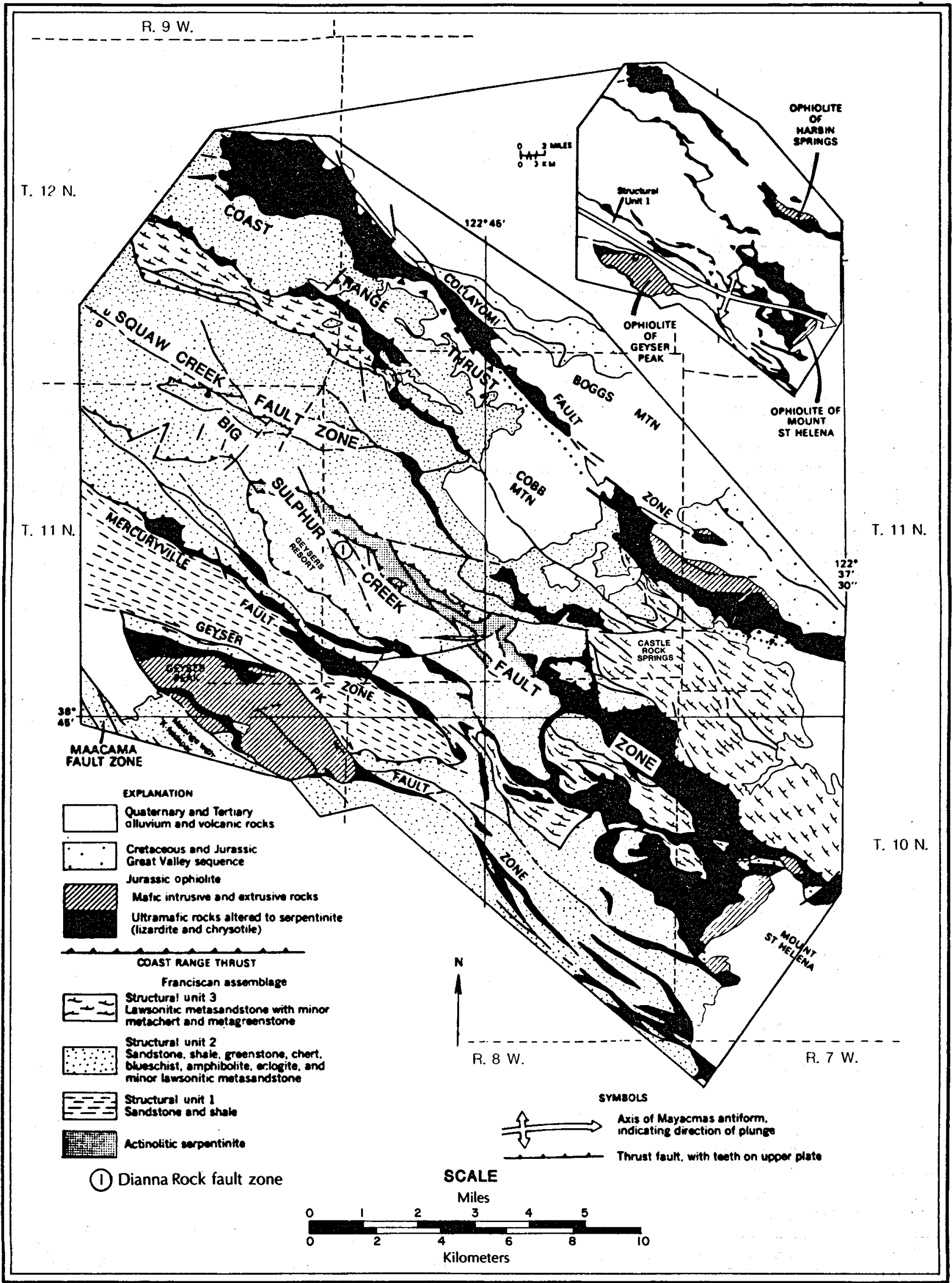

Figure 2. Generalized geologic map of The Geysers Geothermal field and vicinity showing structural units and major fault zones (after McLaughlin, 1977). 
- $2.7 \pm 0.3 \mathrm{~m} . y$. to $1.6 \pm 0.4 \mathrm{~m} . y$. (Schriener and Suemnicht, 1980). A comparison of the ages and lithologies of these cuttings with the volcanics on Cobb Mountain indicates that the well may have penetrated one of the numerous dikes or plugs from an extensive magma body underlying The Geysers. At least one highly-altered, andesitic-appearing dike crops out in the Big Sulphur Creek fault zone in Sec. 34, T. 11N., R. 8W. (R. Thomas, unpublished mapping, 1981). Thin section analysis indicates the rock has been transformed into albite-chlorite-quartz-sericite, and has been thoroughly sheared (Goff, 1981).

\section{Contouring the Top of the Main Graywacke}

A study of over 200 well logs filed with the California Division of Oil and Gas (CDOG) revealed that, in most cases, the main graywacke is easily identifiable and is continuous throughout the geothermal field.

A contour map of the top of main graywacke was constructed for use in interpreting the subsurface geology (Plate II). The contours and faults were drawn as consistently as possible with selected data, aerial photographs, and available surface geological maps. Locations of questionable faults were spot checked in the field.

High well density, as seen in Plate I, generally corresponds with areas of good control. Here, interpretations were made more confidently. However, in several areas with apparently good control, the interpretations were uncertain.

For example, in an area overlying the eastern portion of the Squaw Creek fault zone (Sec. 7, T. 11N., R. 8W.), thick fault blocks of graywacke and argillite at the base of the thrust assemblage may, in places, directly overlie the main graywacke. This graywacke-on-graywacke problem made the selection of some top of main graywacke picks difficult.

Another example occurs near Castle Rock Springs (Sec. 26, T. 11N., R. 8W.) where many wells have been drilled, but logging has been adequate only for the last several years. Here, the contour locations were based on lithology logs for less than half of the existing wells, making interpretations in this area more uncertain.

\section{Structural Features}

Both the subsurface top of main graywacke map (Plate II) and the surface geologic map of McLaughlin (1978) illustrate the great structural complexity of The Geysers area. When used together, the two maps indicate the types and locations of geologic structures, and, in many cases, the degrees of folding and apparent offsets along faults. In general, the following structures are common to the Franciscan Complex and are not considered unique to The Geysers area.

\section{Folds}

Folds, representing ductile deformations of Franciscan rocks, are observed in many scattered rock outcrops. Chert bodies, in particular, show evidence of intense folding. It is likely that other rock units within the thrust assem- blage are also intensely folded and sheared, but due to a lack of distinctive marker beds within the assemblage, it is difficult to determine the type and degree of folding.

\section{Normal Faults}

Normal faults are mapped by McLaughlin (1978) and Goff and McLaughlin (1976) in several areas at The Geysers. These small-displacement, normal faults occur as sets of steeply-dipping faults on the northern, western, and southern slopes of Cobb Mountain, and as several northerly-trending, steeply-dipping faults within the Big Sulphur Creek fault zone (Sec. 13, T. 11N., R. 9W., and Sec.19, T.11N., R. 8W.) (Plate V). Other small-displacement, normal faults probably occur in the intervening areas. However, due to the disrupted nature of the terrain and the wide spacing of subsurface control points, they are not indicated on either the surface geologic map or the top of main graywacke map.

\section{Thrust Faults}

At least two periods of thrust faulting at The Geysers are represented by an older, complex, imbricated series of subparallel, low-angle, thrust faults in the thrust assemblage (associated with Late Jurassic-to-Late Cretaceous regional subduction), and a younger ( Tertiary-Quaternary) imbricated series of high-angle faults with large reverse-slip components (Plate II). Contours on the top of the main graywacke define what regionally may be the basal thrust of the low-angle thrust series. However, locally, the main graywacke body may also be sliced laterally by imbricated, low-angle thrust splays, accounting for the imbrication of structural units and zonal development of cataclasis observed in some drill cuttings.

The younger, high-angle reverse faults are complex, intersecting, west-to-northwesterly trending faults that break the Franciscan Complex into imbricated, northwesterly-trending fault blocks, accounting for the westerly-to-northwesterly trending structural grain of the area. Throughout the area, most of these faults dip steeply to the north and to the northeast. However, along the Big Sulphur Creek and Squaw Creek fault zónes, some faults are vertical. Many of these high-angle faults may be interpreted as being reverse-slip components of large, throughgoing, strike-slip faults. However, because of the lack of recognizable datum planes within Franciscan rocks, it is difficult to ascertain the principal style of faulting.

\section{Strike-Slip Faults}

Recently active (Holocene) strike-slip faulting, representing post-Coast Range thrust tectonism, is described for the Collayami fault zone (Donnelly et al., 1976), and the Maacama fault zone, and is suggested for the Big Sulphur Creek fault zone (McLaughlin and Stanley, 1976) (Fig. 2). In these zones, strike-slip faults trend northwesterly-to-westerly, and dip predominately to the northeast. Within the geothermal field boundaries, many of the longer ( $2 \mathrm{~km}$ or more) mapped faults show primary strike-slip displacement, indicated by the abrupt change in 


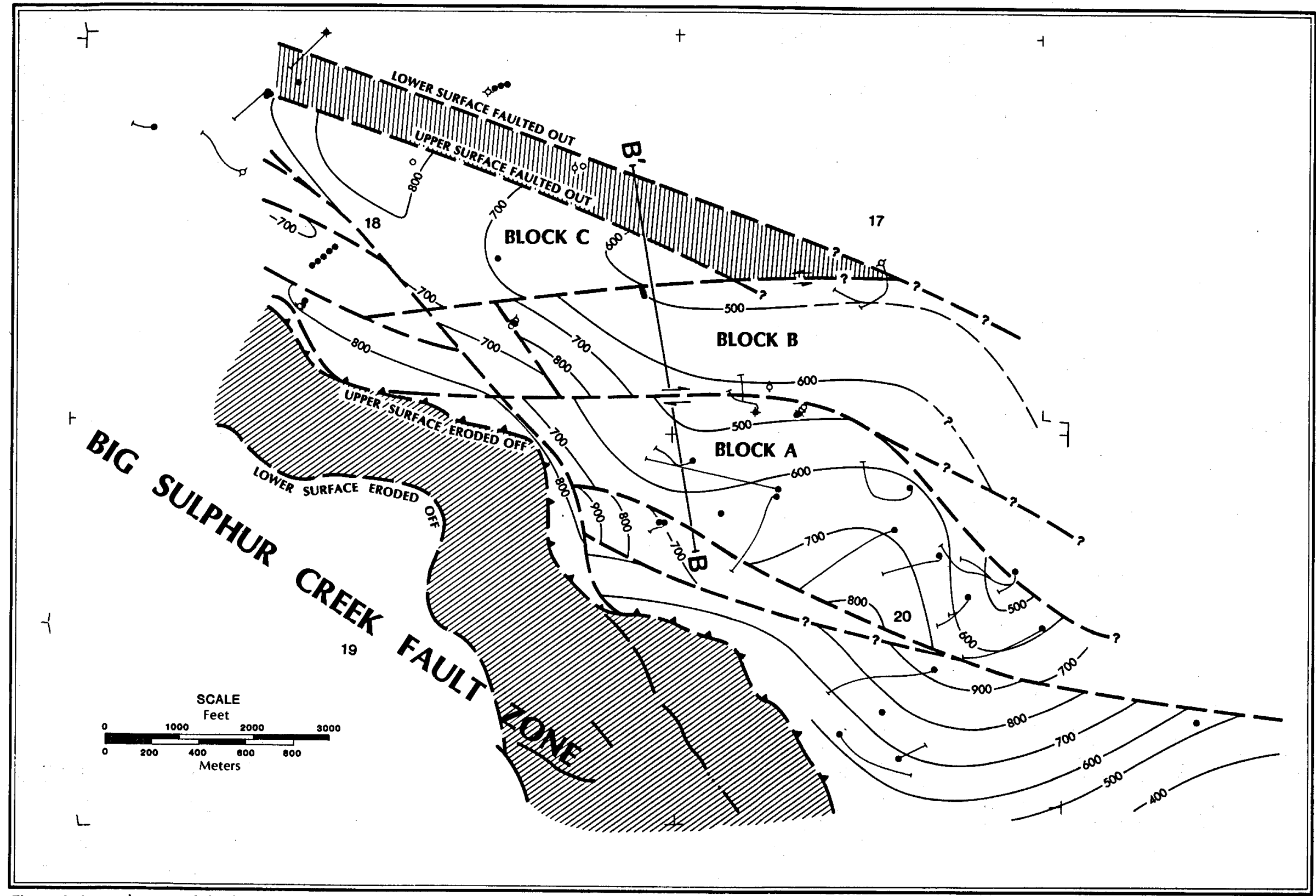

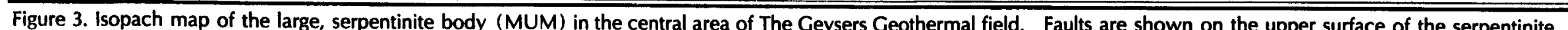
The apparent strike offset of Block A and Block B is illustrated. Cross section B-B' is on Plate III. Contour interval, $100 \mathrm{~m}$. 
lithologic section on offset fault blocks. Locally, right lateral, strike-slip displacement is common. Ar example of this mode of faulting occurs in Sec. 18. T. 11N., R. 8W. (Plate II). Here, the inward curving of the top of the main graywacke may represent drag folds associated with right lateral faulting.

Another example of primary right lateral faulting occurs in Secs. 17 and 18, T. 11N., R. 8W., where a set of westerly-trending, northerly-dipping faults breaks the subsurface rocks into individual fault blocks $A, B$, and C (Plate II ). The fault blocks are identified on Figure 3.

In blocks $A$ and $C$, the base of a large actinolitic serpentinite slab (referred to by McLaughlin and Stanley [1976] as metamorphosed ultramafics [ MUM ])directly overlies the top of the main graywacke. However, in the intervening block B, a $525 \mathrm{~m}(1,722$ feet) sequence of intercalated rock types (melange?) separates the base of the serpentinite slab from the top of the main graywacke, suggesting that block B has been laterally displaced.

To determine the relative direction of strike-slip displacement, an isopach map of the serpentinite body was constructed (Fig. 3). Fault locations are on the upper surface of the serpentinite. As seen on this map, the $700 \mathrm{~m}$ $(2,297$ feet $)$ isopach appears offset $450 \mathrm{~m}(1,476$ feet $)$ along the fault, separating block $A$ from block $B$. This apparent lateral offset suggests right- lateral, strike-slip faulting.

All three blocks are cut off on the west by a prominent en echelon fault that branches off the main trend of the Big Sulphur Creek fault zone. This relationship suggests that faulting occurred along these westerly-trending faults prior to Big Sulphur Creek faulting.

\section{Big Sulphur Creek Fault Zone}

On top of the main graywacke map (Plate II), the northwesterly-striking Big Sulphur Creek fault ${ }^{\mathrm{C}}$ is mapped as a braided zone of near vertical-to-vertical faults offsetting steeply-inclined, northeast-dipping, fault blocks, thereby cutting at an oblique angle across the west-northwesterly structural fabric of the area. However, near the Geysers Resort, the trace of the fault zone doglegs in a somewhat more northerly direction to a point in Sec. 2, T. 11N., R. 9W. where it merges with the northwesterlytrending Squaw Creek fault zone. In the southeastern portion of the geothermal field, the trace of the fault zone leaves the Big Sulphur Creek Canyon and continues on the ridge top along the boundary between Lake and Sonoma Counties.

The overall, northwesterly trend of the Big Sulphur Creek fault zone is subparallel to the throughgoing, Quaternary Maacama and Collayami fault zones. McLaughlin (1981) points out that the orientations of most of the subsidiary faults of the San Andreas system are consistent with the current stress regime suggested by microearthquake, first-motion studies made of The Geysers (Bufe, 1980). The persistent, regional trend of the

c The Big SulphurCreek fault zone referred to in this report is not the same as that referred to by McLaughlin. According to him, (McLaughlin, 1980), the fault zone coincides largely with older, lower-angle thrust faults along the northern side of Big Sulphur Creek. high-angle faults in the Big Sulphur Creek fault zone suggests that the faults may have developed contemporaneously, and are associated with a wrench fault structural style similar to the Maacama fault zone, and, possibly, the Collayami fault zone.

Wrench faulting is suggested as a mechanism for development of large, right-lateral, strike-slip faults in the Los Angeles Basin and the San Joaquin Valley (Harding, 1973), and is also considered by Hearn et al., (1981) to explain fault patterns and volcanic venting patterns in the Clear Lake Volcanics to the east of The Geysers.

Wrench faulting is suggested for the Big Sulphur Creek fault zone because 3 of the 4 structural features identified by Wilcox et al., (1973) as common to basic wrench faults are present. The features are shown diagramatically on the strain ellipses included with Plate V. Several locally occurring examples of the structural features are:

1. Portions of the main wrench occur along Big Sulphur Creek in Sec. 29, T. 11N., R. 8W. The main wrench appears as a pair of steeply-inclined faults that trend parallel to the overall trace of the wrench zone;

2. In the northwest corner of the same section, the main wrench merges into the left-stepping, en-echelon, right-lateral, strike-slip (synthetic) faults of the Dianna Rock fault zone. This type of faulting is typical of wrenching in the early stages of deformation (Wilcox, 1973); and

3. Near the northwest boundary of the field (Sec. 1, T. $11 N$, R. 9W.), a set of northeast-trending, left-lateral, strike-slip (antithetic) faults occur. These faults, trending at almost right angles to the main wrench, are common in wrench fault systems.

\section{Fractures}

Most Franciscan rocks at The Geysers are pervasively sheared and fractured, as evidenced in rock outcrops (Photo 2) and core descriptions. Within the reservoir, hydrothermal fluids occupy and flow through open fracture networks (Photo 3 ). These productive fractures occur primarily in the highly-impermeable main graywacke. However, they are found locally in underlying volcanic intrusives and in the overlying thrust assemblage. The lower frequency of steam entries in the overlying rocks may be a coincidence, or it may be caused by the thrust assemblage acting as a permeability barrier for ascending steam (McLaughlin and Stanley, 1976; McLaughlin, 1977, 1981).

Well data indicate that within the main graywacke, the productive fractures frequently occur in clusters, separated by large intervals of unproductive rock (Plate III). The unproductive rock may either contain open fractures not connected to the reservoir or fractures sealed by hydrothermal mineralization.

In descriptions of productive fractures within The Geysers Geothermal field, Jamieson (1976) and Capuano (1979), working with limited data, suggest that steam flow occurs in near vertical, open fractures. However, geologic cross sections in the northern and central areas of the field (Plate III and unpublished mapping) indicate that steam entries commonly align in subhorizontal to moderately-dipping trends, not expected for a reservoir in which vertical, open fractures predominate. This alignment sug- 


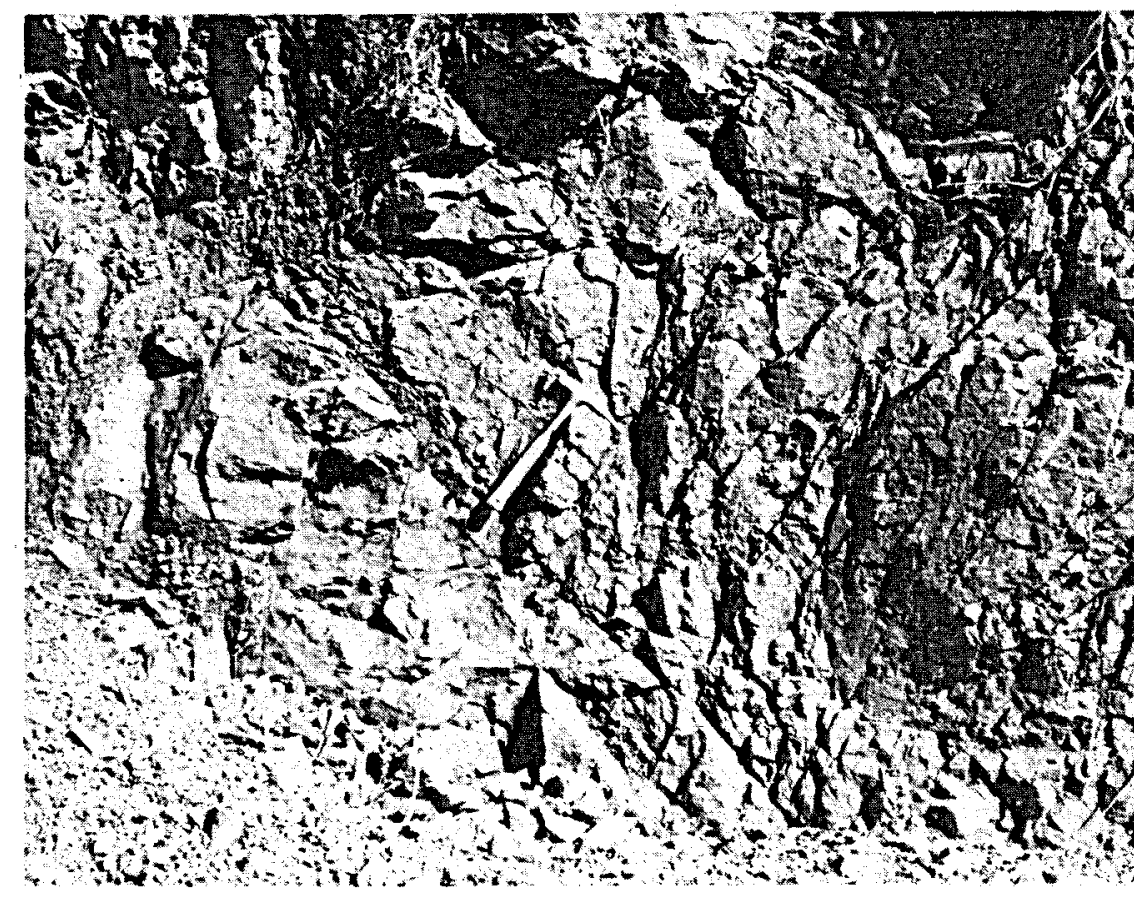

Photo 2. Pervasively fractured graywacke, The Geysers Geothermal field.

gests that the productive fractures are interconnected laterally, and serve as channelways for lateral steam migration.

Reservoir pressure decline maps by Lipman et al., (1978) support this concept of steam flow through an extensive system of laterally interconnected fractures. Nevertheless, the concept may not apply locally, due to the geologic and fluid flow complexities of the geothermal field.

\section{GEOMETRY OF THE RESERVOIR TOP}

\section{Contouring the Depth of First Steam}

To assist in interpreting the fluid-flow regime, a computer-generated map, contoured on first reported steam entry, was constructed from well histories (Plate IV). (A perspective view of this map is on page 8. ) The map on Plate IV roughly defines the roof of the steam portion of the reservoir. The contours undulate in some areas because of the heterogeneous character of the reservoir, failure by the driller to recognize the first steam entry, or a failure to report first steam entry.

Microscopic inspections of cuttings from some of the wells indicate that hydrothermal minerals frequently occur in fractures, coinciding, in depth, with the locations of predicted first steam entries. During development of the hydrothermal system, open fractures at these horizons may have been sealed by hydrothermal mineralization. Therefore; where two adjacent wells first encounter steam at significantly different depths, an assumption is often made that the shallower first steam entry is closer to a generalized reservoir top.

Taking this assumption into consideration, some contours on the computerized map were locally smoothed and an idealized top of first steam entry map constructed (Fig. 4). This idealized map reveals five, distinct steam

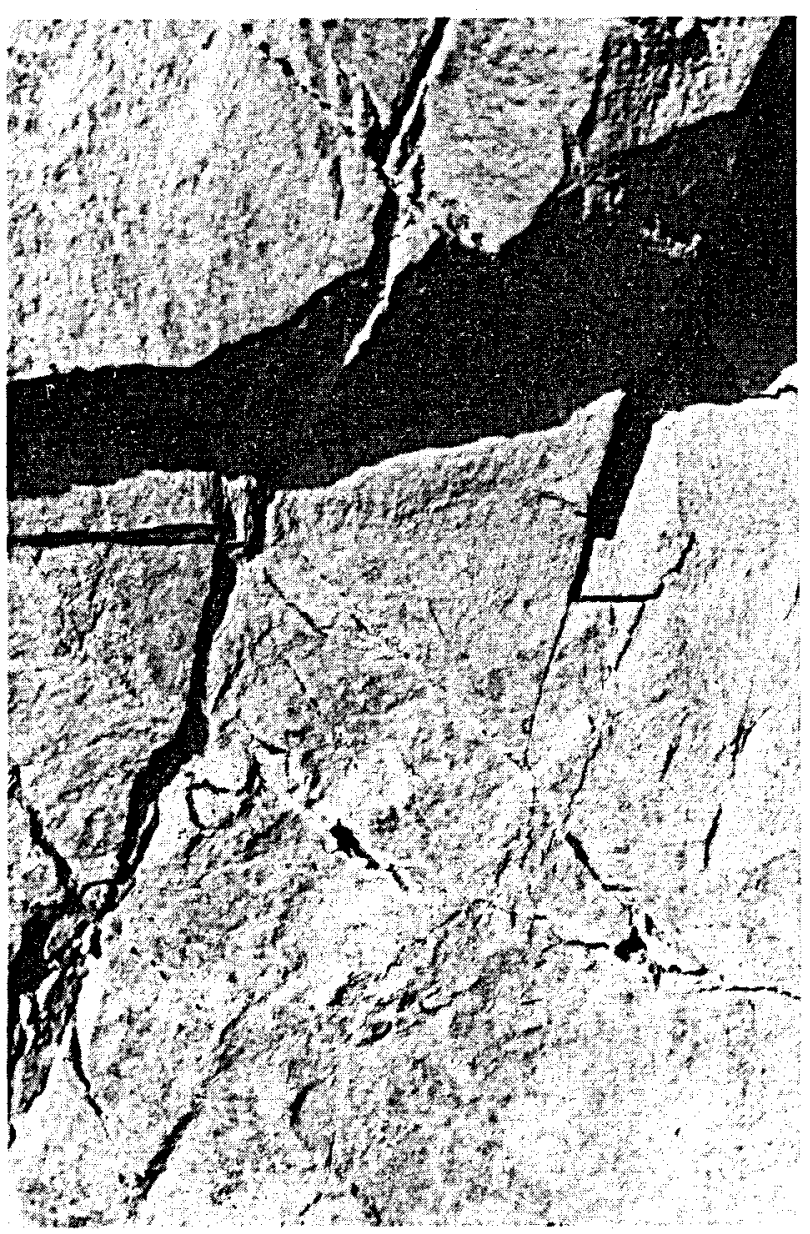

Photo 3. Fractured graywacke showing open fractures, some with quartz-lined vugs. 


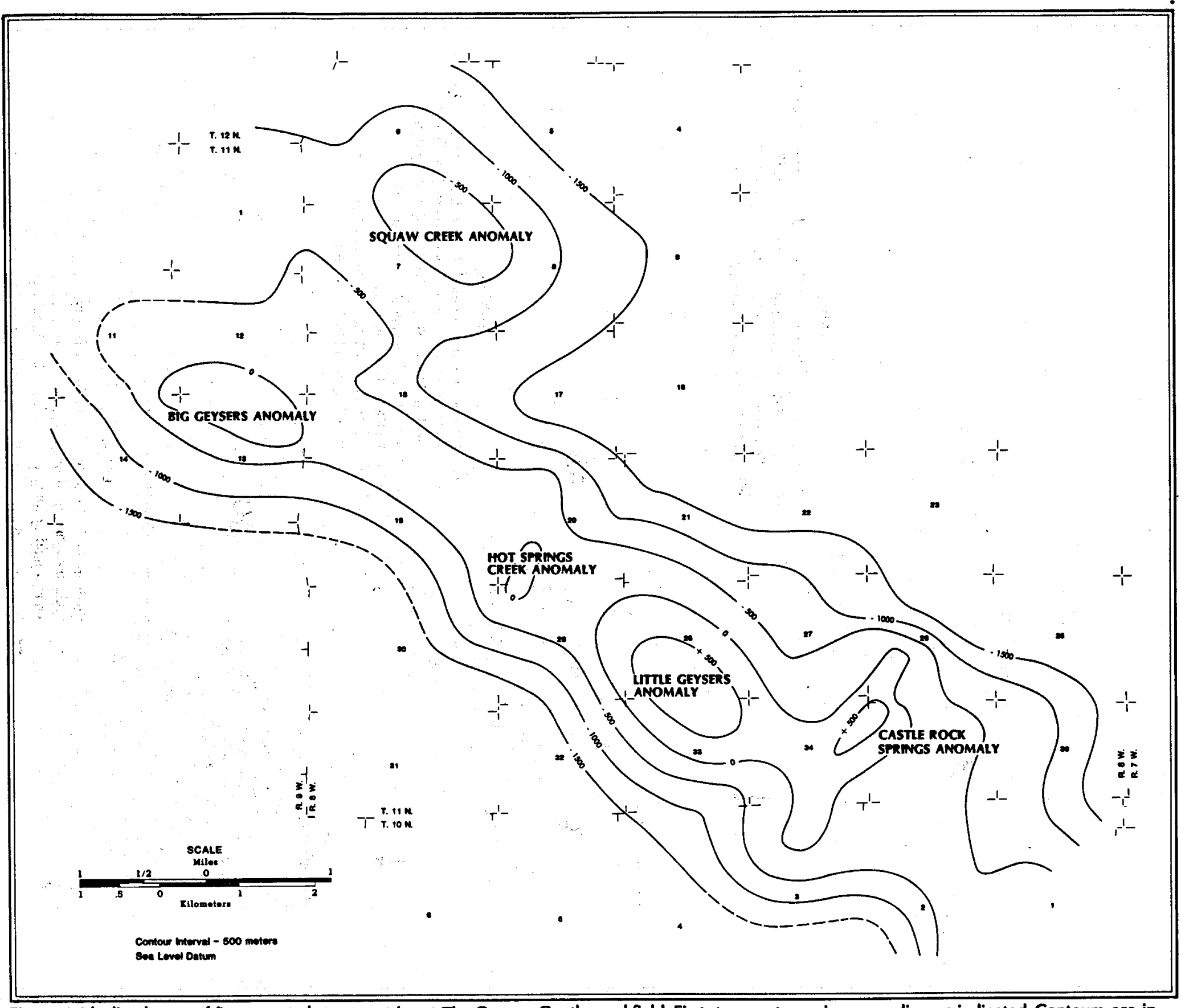




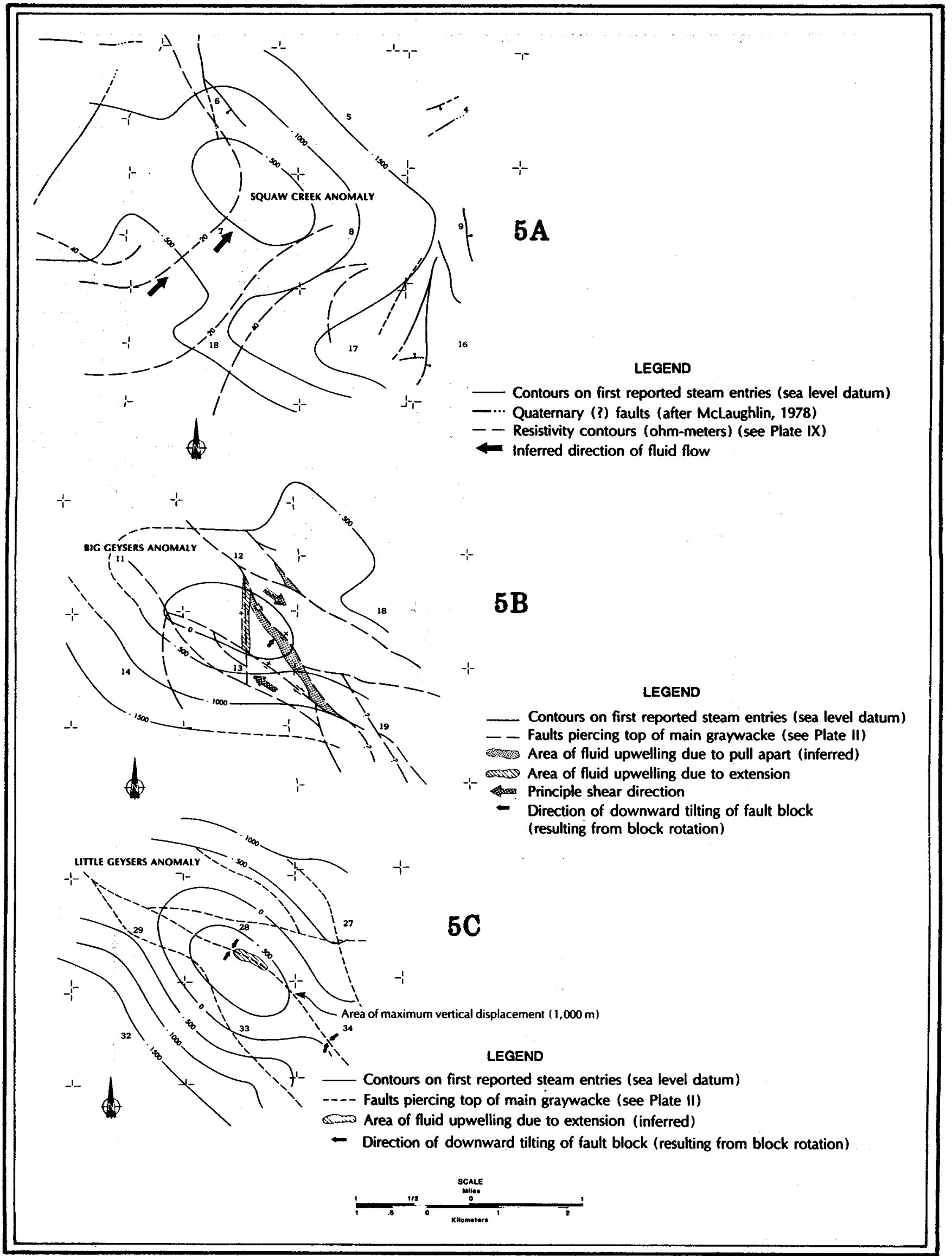

Figure 5. Three first steam entry anomalies at The Geysers Geothermal field. Inferred directions of hydrothermal fluid flow and areas of fluid upwelling are indicated. 
- entry anomalies that are herein referred to as the Squaw Creek, Big Geysers, Hot Springs Creek, Little Geysers, and Castle Rock Springs anomalies. The geographic coincidence of these anomalies with mapped structures suggest that steam flow may be structurally controlled.

\section{First Steam Entry Anomalies Squaw Creek Anomaly}

The northernmost anomaly, Squaw Creek, is a large lobe through which steam production is extended $5.5 \mathrm{~km}$ (3.4 miles) northeast of the Geysers Resort (Fig. 4). As shown on Figure 5A, a narrow, northeasterly-trending, resistivity low bisects the anomaly, suggesting that a northeasterly-trending fault or fracture may be a pathway for geothermal fluid flow between one of the Big Sulphur Creek fault zone splays and the northeastern perimeter of the anomaly. If such a fault exists, it may be a very small displacement, antithetic fault and, therefore, unmapped. The area circumscribed by the $-500 \mathrm{~m}$ contour probably represents the area from which steam may have migrated to structurally higher graywacke fault blocks in the coincidently located Squaw Creek fault zone (Fig. 2, Plate II).

\section{Big Geysers Anomaly}

Adjacent to the Squaw Creek anomaly, on the southwest, is the Big Geysers anomaly (Fig. 4). Here, numerous hot springs and fumaroles vent fluids in an area of extensively altered main graywacke and slide debris (Allen and Day, 1927). Due to the presence of shallow steam, the area overlying the Big Geysers anomaly was the first to be developed at The Geysers. The location of the sea level $(0 \mathrm{~m})$, first steam entry contour of the Big Geysers anomaly roughly coincides with the surface area where hydrothermally altered rock is exposed. McLaughlin and Stanley (1976) suggest that major channelways from the reservoir may be the northwesterly-trending strike-slip and normal faults, along which hot fluids now vent to the surface.

A wrench fault model may explain the occurrence of the Big Geysers anomaly. In the model, the northwesterlytrending dogleg bend of the Big Sulphur Creek fault zone represents a releasing bend (Crowell, 1974). As a result of the more westerly-trending regional stresses, this bend may serve as a zone of pull-apart extension. Within the zone, between the intersection of the northerly and northwesterly trending faults, shown on Figure 5B, a fault block representing a pull-apart wedge is tilted to the northeast. This suggests that the maximum extension is along the northeastern and western edges of the block. On the figure, stippling represents the areas of maximum extension that may have intermittently served as zones of fluid upwelling. Currently, fluid upwelling may be confined to the northerly-trending normal fault.

\section{Hot Springs Creek Anomaly}

Although the Hot Springs Creek anomaly, $3.7 \mathrm{~km}(2.3$ miles) southeast of the Geysers Resort, is not extensive in area, it does contain several of the more productive wells in the geothermal field. The long axis of this anomaly trends $\mathrm{N} 23^{\circ} \mathrm{E}$ from a small area of hydrothermally altered rock and hot springs. Felsite intrusives have been noted in several wells along the main wrench fault.

The center of the anomaly coincides with the easternmost en echelon strike-slip fault of the Dianna Rock fault zone. Regional stresses, acting on the northwest-trending synthetic faults, may have created pull-apart wedges similar to those inferred for the Big Geysers area. The northeast trend of the long axis of the anomaly suggests that an unmapped antithetic fault or fracture acts as a pathway for fluid migration to the northeast.

\section{Little Geysers Anomaly}

The Little Geysers anomaly, $6.2 \mathrm{~km}$ ( 3.9 miles) southeast of the Geysers Resort, underlies the second largest hydrothermally altered area in the geothermal field (Fig. 4). Numerous hot springs vent to the surface in the area. The anomaly is shaped like an elongated antiform, with the long axis parallel with the main trend of the Big Sulphur Creek fault zone. Felsite intrusives have been noted in several wells; at least one dike, previously described, is exposed at the surface along the trace of the main wrench fault.

The main wrench fault ( Fig. $5 \mathrm{C}$ ), crossing northwesterly through the anomaly, separates two, inwardly-dipping fault blocks, suggesting that wrench-related, fault block rotation occurred in this area and extended along the main wrench fault trend to the southeast. The center of the anomaly nearly coincides with the point of maximum vertical fault offset $(1,000 \mathrm{~m}$ or 3,280 feet $)$. This segment of the main wrench fault may have resulted from a local extension. During deformation, the fault segment may have been a weak zone where silicic, igneous rocks were intruded. Currently, it may be a zone of upward, hydrothermal fluid migration.

\section{Castle Rock Springs Anomaly}

The Castle Rock Springs anomaly is the southeasternmost anomaly identified (Fig. 4). The few hydrothermal surface manifestations in the area occur at Castle Rock Springs and Anderson Springs. However, hydrothermally altered rock is encountered at depth in many wells drilled in the area. Felsite intrusives have also been identified here.

The long axis of the Castle Rock Springs anomaly strikes $\mathrm{N} 30^{\circ} \mathrm{E}$, in a trend similar to that of the Squaw. Creek and Hot Springs Creek anomalies. The surface area overlying the Castle Rock Springs anomaly shows strong northeasterly-trending lineations, suggesting that an unmapped, northeasterly-trending fault or fracture may serve as a lateral conduit for fluid migration.

\section{HYDROTHERMAL FLUID FLOW REGIME}

Several theories have been proposed to explain the fluid flow regime of the geothermal reservoir and its relationship to the geologic structure. Unfortunately, these descriptions remain speculative due to the geologic complexity of the field and the need for more critical geologic and engineering data.

In the generalized fluid flow model of a vapor-dominat- 
ed hydrothermal system proposed by White et al., (1971), three components must be present for a vapor phase to dominate: 1) a high-temperature heat source, 2) sufficient fracture permeability, and 3) low water recharge.

White describes an essentially closed hydrothermal system with an areally extensive two-phased zone of ascending steam and descending condensate. The zone is bounded from below by a hot water (brine) table heated by the magma source through conduction, and, from above, by a zone of steam condensation. In the upper condensation zone, condensed steam loses some heat to overlying rocks before flowing back to the lower, hot water table.

Based on his own geologic work, and on geochemical and geophysical studies by the U.S. Geological Survey, McLaughlin (1977) proposed a structural model to explain the structural-fluid flow regime at The Geysers. In the model, steam boils off from a hot brine table to the northeast and flows upstructure (to the southwest) through fracture networks in favorably-fractured graywacke thrust slabs. These slabs cover an extensive area, and would be the host rock for White's two-phase zone. Other overlying thrust slabs, coincident with the basal thrust assemblage, may be acting locally as a reservoir cap.

McLaughlin suggests that, at one time, the reservoir may have been a larger, water-dominated reservoir venting fluids through the Mercuryville fault zone, southwest of the Big Sulphur Creek fault zone. As the hot water boiled off and the reservoir became steam-dominated, venting activity shifted down dip from the Mercuryville fault zone to the coincidentally located, high-angle faults along Big Sulphur Creek. Some of the high-angle faults located in the Dianna Rock fault zone may currently vent steam condensate from the reservoir, as attested to by the presence of hot springs and fumaroles.

Basing a generalized fluid-flow model of a vapor-dominated system on lateral changes in noncondensible gas concentrations observed at Larderello and The Geysers, D'Amore and Truesdell (1979) suggest a significantly different hypothesis of the fluid flow regime. In their model, steam boiled off from the deep water table flows upward in zones of limited extent. Then, the steam flows laterally (horizontally) while incrementally cooling, condensing, and descending as water to the hot water (brine) table, thus forming a circular convection system. The initial lateral permeability increases as minerals in the rock are dissolved by the newly-formed condensate.

\section{Wrench Fault Model}

The concept of zonal upflow, lateral spreading, and dissolution, coupled with structural interpretations, form the basis for a new, structural, fluid-flow model for The Geysers reservoir.

\section{Development of the Hydrothermal System}

In the portion of the model describing the structural and hydrothermal development of the reservoir, deep-seated, wrench-style faulting and fracturing is postulated to have occurred along the ancestral Big Sulphur Creek fault zone.
At the inception of wrenching, strike-slip, high-angle thrust, and normal faults pierced deeper portions of the reservoir. Faulting and extensive fracturing occurred in the weakest zones, which later were intruded intermittently by igneous rocks, like the dike rock previously described. Later, these faults and associated fractures acted locally as vertical conduits for hydrothermal fluid migration into upper portions of the reservoirs, and, on occasion, to the surface.

The wrenching may have begun at least 1.6 million years ago, as suggested by the dates - of rhyolite cuttings (Schriener and Suemnicht, 1980). The age of the most recent faulting had not been determined.

Concurrent with the deep-seated wrench faulting, extensional zones of weakness developed within the main fault trend, with other zones of weakness (broken by normal and conjugate faults and fractures) developing at angles to the main wrench. New fractures formed and old fractures reopened, allowing initial hot water flow into the developing hydrothermal (hot water?) system. The hydrothermal system continued to develop over a protracted period. During this period, hot water, through a dissolution and deposition process, created extensive lateral networks of open fractures through which steam currently flows.

\section{Current Fluid Flow Regime}

The idealized contour map of first reported steam entry at The Geysers Geothermal field is a useful tool for interpreting the current fluid flow regime (Fig. 4). Contours on this map:

1. Roughly define locations of conduits from a deep source to the top of the reservoir, assuming that the centers of the anomalies coincide geographically with the fluid conduits;

2. Describe an upper boundary on the steam portion of the reservoir, under current equilibrium conditions; and

3. May suggest the lateral boundaries of the field under current equilibrium conditions.

In the portion of the model describing the current fluid flow regime at The Geysers, hydrothermal fluid is postulated as rising through conduits beneath the main anomalies along the Big Sulphur Creek wrench trend (Fig. 6). A recently completed well, "GDC" 10, Sec. 29, T. 11N., R. 8 W., tested at $177,811 \mathrm{~kg} / \mathrm{hr} .(392,000 \mathrm{lb} . / \mathrm{hr}$.$) ,$ the highest flow rate in the field to date (Magma Power Co., 1980). The well may have penetrated one of the major steam conduits.

The hydrothermally altered rock above the conduit and above several other anomalies may be altered by condensate leaking at or near the surface (McLaughlin and Stanley, 1976, and McLaughlin, 1981). Alternatively, the altered rock may result from the circulation of hot, meteoric waters.

After cresting in the reservoir, the steam spreads out and flows down into open fracture networks, eventually merging with the steam flow from neighboring anomalies (Fig. 4). In areas where permeable, unsaturated rock is present at high levels, the steam gives up heat to the 


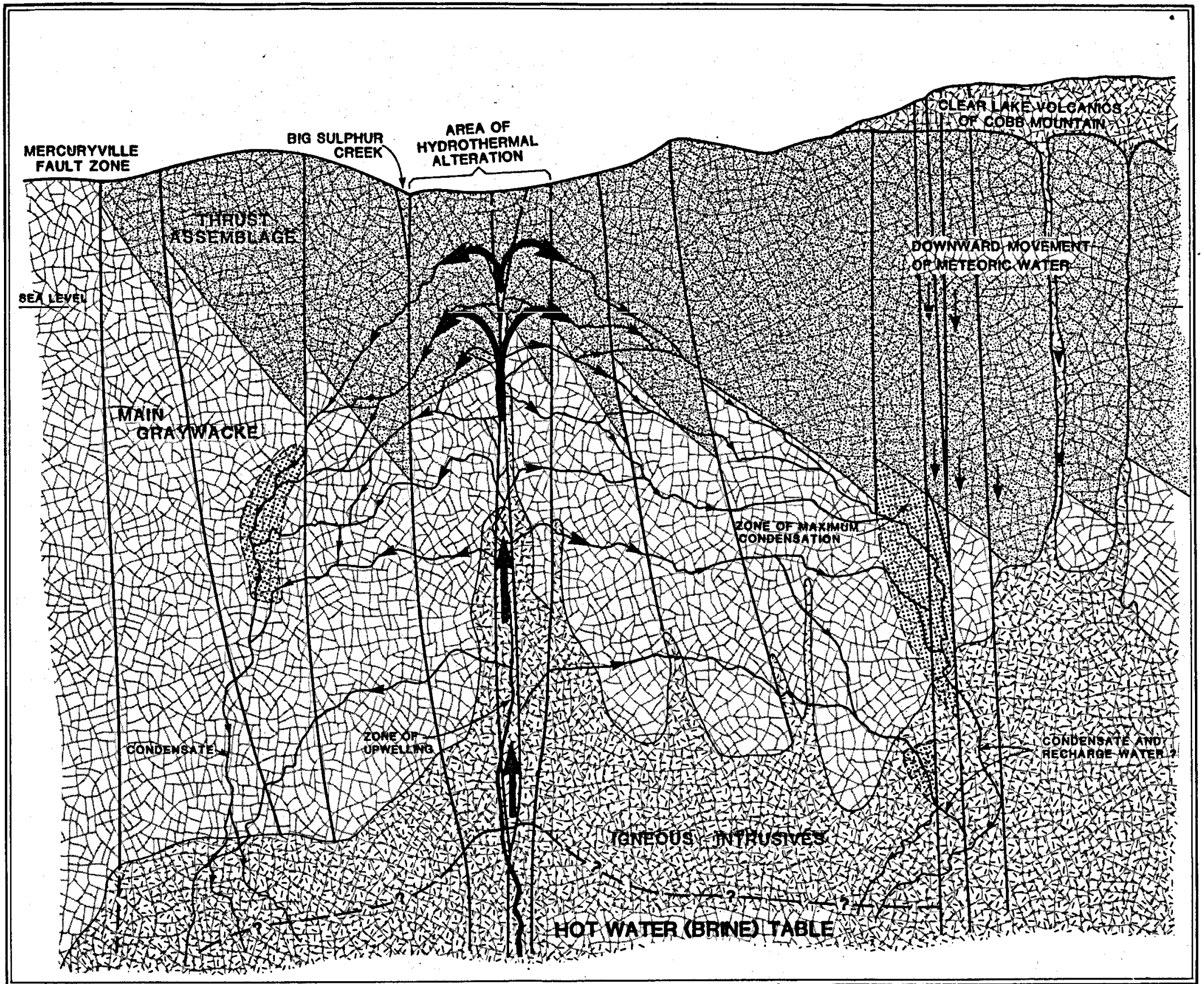


overlying rock, condenses, and drains into unsaturated rock. The zone where this takes place corresponds with the zone of condensation of White et al., (1971). In other areas, particularly where the remainder of the steam (in phase with incrementally cooled condensate? ) contacts progressively cooler rock and possibly descending meteoric water, the steam cools rapidly, condenses, and descends as hot condensate to the hot water (brine) table. This zone of maximum condensation would form the steep flanks of the reservoir.

At The Geysers, the existence of a maximum condensation zone is suggested locally by well data. In some areas, wells drilled to the steam zone encounter large volumes of hot water above the first steam horizon.

The lateral component of the fluid flow regime, for the most part, appears to dip down and away on a constant gradient, only locally affected by the complex pattern of older (pre-Quaternary) faults seen on the top of main graywacke map (Plate II). These older, gouge-filled faults, while possibly offsetting reservoir rocks of variable permeability, do not seem to act as conduits to fluid flow.

This apparent lack of control by the older faults suggests that, during the development of the system, the lateral spread of fluid was not restricted to existing open fractures. Instead, the fluid independently developed channelways through both fractured and unfractured rock by a process of active dissolution and deposition. Thus, the distribution of any one channelway would have been greatly influenced by the geochemical and physical environments in which both the fluid and the rock coexisted.

In the northeasterly-trending anomalies (Squaw Creek, Hot Springs Creek, and Castle Rock Springs), some ascending steam may branch off at a lower structural level and flow through large, upward-spreading dissolution channels coincident with antithetic or extensional faults and fractures. Alternatively, steam may spread laterally through the same structures after reaching a higher structural level.

\section{Cap Rock}

The relationship between the suggested cap rock (thrust assemblage) and the reservoir is not clear. The regionally persistent, southwesterly and northeasterly dip of the first reported steam contour is away from the axis of the Big Sulphur Creek fault zone (except for local northwest and southwest dip away from the axis of the northeast-trending anomalies). When these dips are superimposed on the regional, northeasterly dip of the Franciscan rocks, it is seen that the thrust assemblage cannot act as a cap rock except on the northeast. Even on the northeast, the base of the thrust assemblage may be merely coincident with the top of the reservoir, since first steam entries often occur at other structural levels.

\section{Field Boundaries}

The commercial steam boundaries of The Geysers Geothermal field are not yet known. However, there are several areas where Quaternary structures may form the boundaries. For example, near Cobb Mountain (Secs. 16, 17 , and $21, T$. 11 N., R. $8 W$.), the trace of the $-1500 \mathrm{~m}$ first steam entry contour wraps around an area pierced by many Quaternary(?) normal faults. The contour lies between the southwest edge of the very permeable Cobb Mountain volcanic rocks described by Goff et al., (1977) and the productive areas of the field (Plate V). The southwesternmost and westernmost of these Quaternary (?) faults, as mapped by McLaughlin (1978), both change trend and terminate near the trace of the $-1500 \mathrm{~m}$ contour. This relationship suggests that these faults, and possibly other Quaternary(?) faults, may help to limit lateral steam migration by acting as drainage channels to cool, meteoric waters and, at deeper structural levels, to steam condensate. Another Quaternary (?) fault to the northwest (Sec. 36, T.12N., R. 9W.) roughly coincides in location and trend with the $-1500 \mathrm{~m}$ contour, and may also act as a drainage channel for descending cool water. Additional cool water drainage may also occur through several volcanic pipes in Cobb Mountain, as suggested by Goff et al., (1977).

As shown on Plate $V$ and Figure 4 , the $-1500 \mathrm{~m}$ steam entry contour roughly coincides with locations of marginal wells throughout the field. Most wells drilled outside the area enclosed by the contour have been noncommercial. Therefore, the $-1500 \mathrm{~m}$ contour may define the steepened flanks of the reservoir. If so, the reservoir boundaries may be established presently only in the northeastern and southwestern portions of the field. 


\section{GEOPHYSICS}

The value of geophysical data in geothermal resource exploration at The Geysers Geothermal field and vicinity is discussed in this chapter. All available published and unpublished geophysical data and data interpretations for the field were gathered, and additional analyses and interpretations were performed, as needed. No original field work or field checks were made.

Since commercial steam production at The Geysers Geothermal field began in 1960, many geophysical surveys have been made of the area by governmental, university, and private sources. Little of the extensive work by private companies is available to the public. Thus, this study includes, for the most part, analysis and interpretation of work done by the U.S. Geological Survey, the California Division of Mines and Geology (CDMG), and several universities. Data from an anonymous source were also used. Confidential drill hole logs and data in the files of the California Division of Oil and Gas (CDOG) were helpful, as well.

The first, published, geophysical survey of The Geysers geothermal field was a reconnaissance gravity study by the CDMG (Chapman, 1966) ${ }^{\wedge}$ In 1968, an áeromagnetic survey and a ground magnetometer profile of the area were completed by the CDMG and a microearthquake study was completed by the Stanford Research Institute (Lange and Westphal, 1969).

As a part of a national geothermal program, the U.S. Geological Survey began a major investigation of The Geysers area in the early 1970's. The investigation included additional gravity surveys, an aeromagnetic survey, a reconnaissance electrical resistivity survey, microearthquake studies, a seismic refraction study, a seismic Pwave delay study, some audio-magnetotelluric data, and a reservoir analysis from gravity data.

Other recent data include a seismic reflection survey and reservoir evaluation from gravity data by Stanford University, a microearthquake study by the University of California, and a reconnaissance electrical resistivity survey by a private source.

\section{GRAVITY DATA}

\section{Bouguer Gravity and Residual Gravity Maps}

Bouguer gravity and residual gravity maps that include The Geysers Geothermal field (Fig. 7) have been pub-

A Bibliographical data for references in this chapter are in the Ceophysics section of the list of Selected References at the end of the report. lished by the CDMG (Chapman, 1966, 1975) and by the U.S. Geological Survey (Isherwood, 1976a, 1976b). The two residual gravity maps prepared for this report (Plates VI and VII) include all of the gravity data available for the area.

The most prominent gravity anomaly on Plate $\mathrm{VI}$ is a nearly circular negative anomaly with an amplitude of more than 25 milligals (mgal), centered near Mt. Hannah, about 10km (6.2 miles) northeast of The Geysers Geothermal field. The interpretation of this anomaly has been discussed in detail by Chapman $(1975,1978)$ and Isherwood (1975). It is generally agreed that the cause of the anomaly is probably a partially molten intrusive mass below the area between The Geysers and Mt. Hannah. In the analysis by Chapman (1975), the proposed intrusive mass has the form of a truncated cylinder tilted toward the southwest at an angle of about $\mathbf{4 5}$ degrees from the vertical, with a radius of about $6 \mathrm{~km}$, a depth extent of about $9 \mathrm{~km}$, and its top about $3 \mathrm{~km}$ from the ground surface (Fig. 8). However, more recent information from seismic data (lyer and others, 1979) indicates that the distance to the top of the anomalous mass should be no less than about $4 \mathrm{~km}$. Isherwood (1975) modeled the source for the main anomaly with a sphere that has a depth to the center of $13.5 \mathrm{~km}$. Schriener and Suemnicht $(1980)$ have reported that rhyolite, possibly apophyses of the magma chamber, has been found at depths of about $2.5 \mathrm{~km}$ in many drill holes in The Geysers Geothermal field.

\section{Local Anomalies}

Residual maps may be drawn that emphasize the relatively local anomalies in The Geysers Geothermal field, after the gravity effect of the hypothetical magma chamber is removed from the observed gravity data. Such maps have been prepared by Isherwood (1975) and Chapman (1978) using somewhat different assumptions. Plate VII is a residual map modified from Chapman (1978), and Figure 7 is a similar map by Isherwood (1975). Both maps show the same major features, but the anomalies differ in detail and magnitude.

Plate VII includes a large number of local anomalies, many with distinct northwesterly trends similar to the regional structural trends. One of the more prominent positive anomalies, with a maximum amplitude of about 8 mgal, is just southwest of the Collayomi fault zone. The anomaly extends, northwest to southeast, along a linear zone from west of Lakeport to the vicinity of Middletown. 


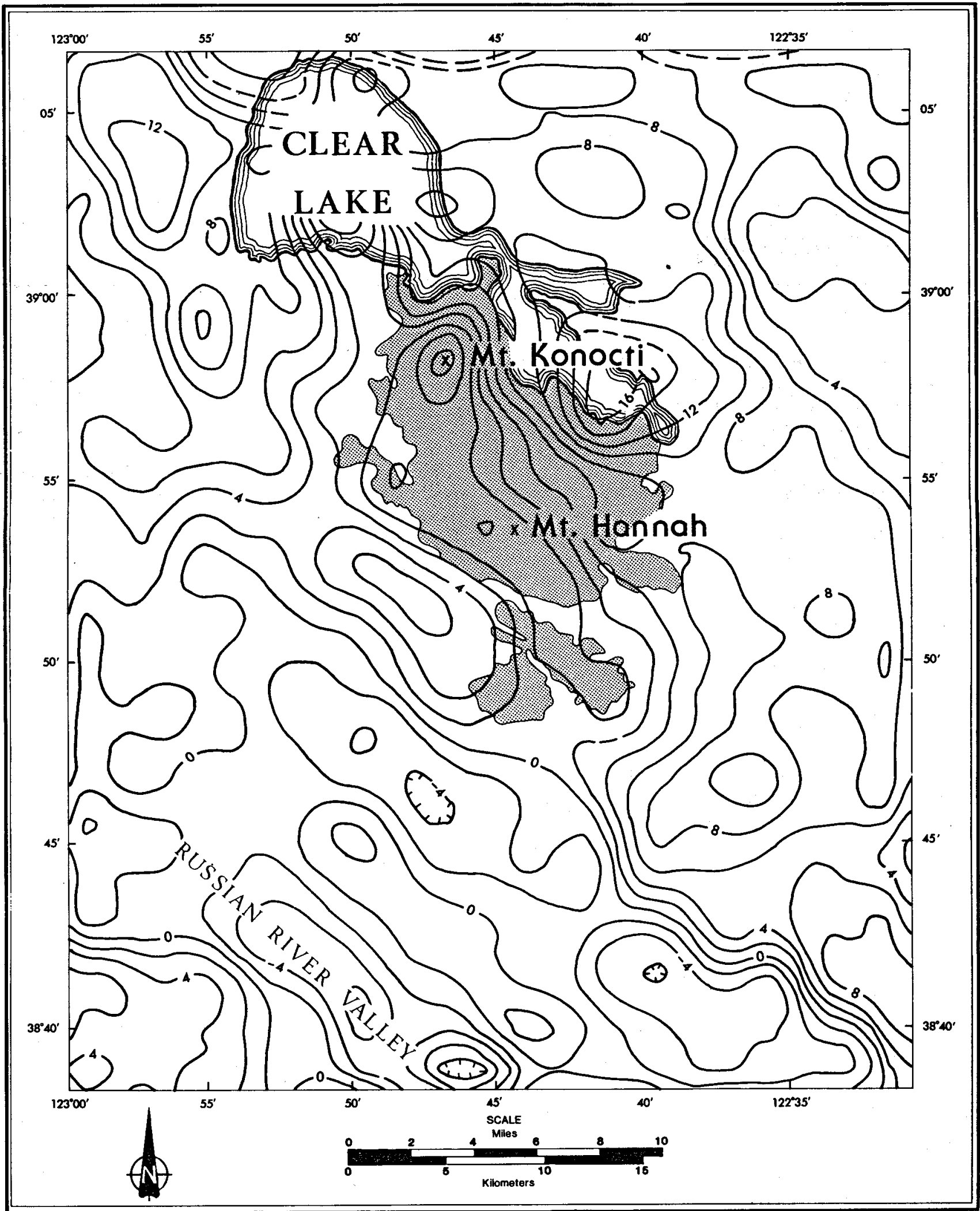

Figure 7. Residual gravity (at $2.67 \mathrm{~g} / \mathrm{cc}$ ) in the vicinity of The Geysers Geothermal field, after removal of the field from a sphere buried at $13.5 \mathrm{~km}$. Contour interval: 2 mgal. After Isherwood (Fig. 16, 1975). 


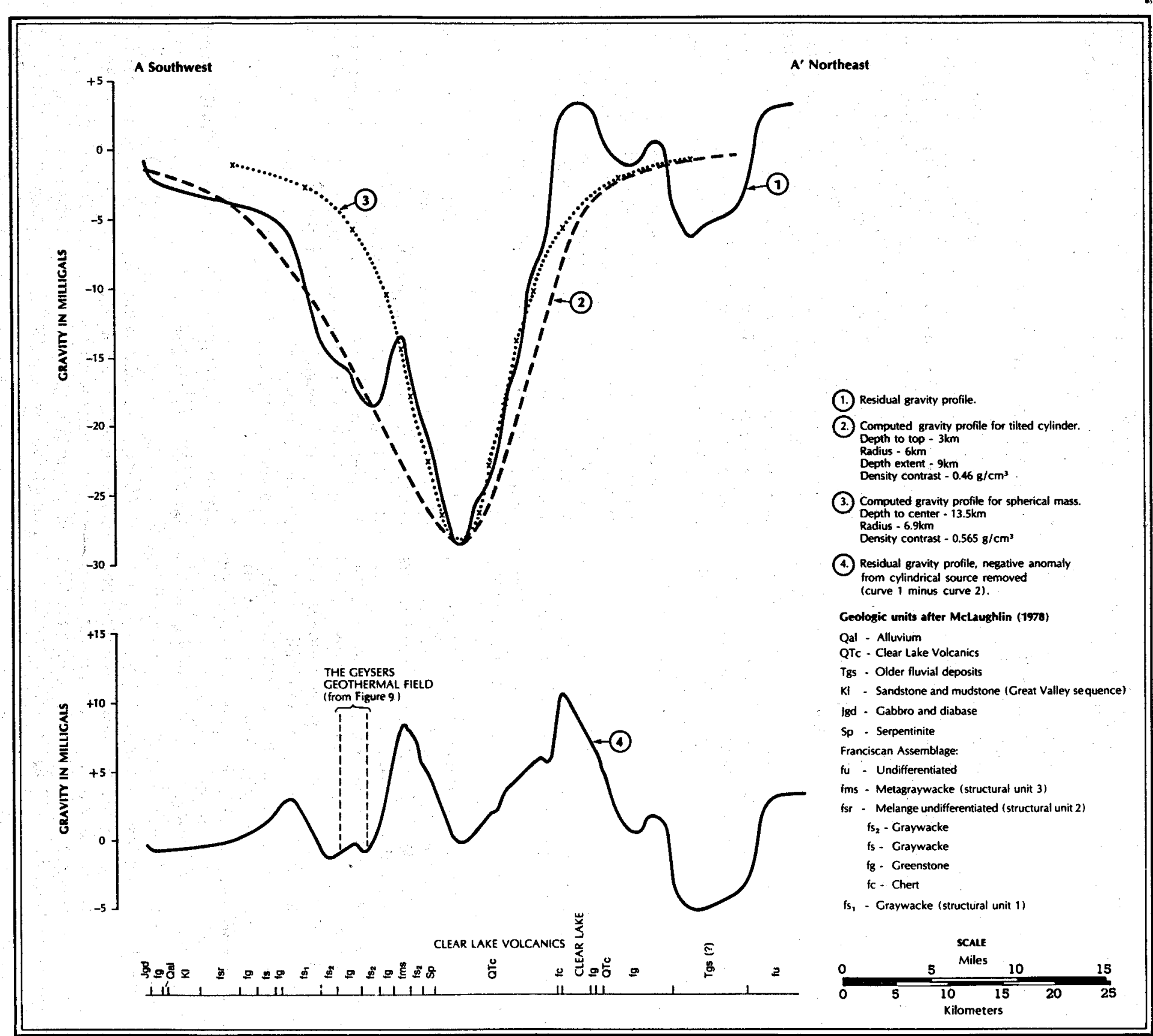


The anomaly is significant because it is the gravity ridge that apparently divides the large negative anomaly on the residual map of Plate VI into two closures. At least in part, this positive anomaly correlates with McLaughlin's (1978) structural unit 3, a unit consisting, in part, of relatively dense, metamorphic, Franciscan rocks (Fig. 9). Although insufficient sampling has been done to determine an average density for this rock unit, a value about $0.1 \mathrm{~g} / \mathrm{cm}^{3}$ greater than the surrounding Franciscan rocks probably would be sufficient to cause the anomaly. Greenstone, some of which is also present along the anomaly trend, may also contribute to the gravity high. Greenstone has an average density of about $2.9 \mathrm{~g} / \mathrm{cm}^{3}$.

This positive metamorphic anomaly is associated with rocks structurally just below the Coast Range thrust. The anomaly is similar to gravity anomalies associated with other rocks located elsewhere below the Coast Range thrust (Griscom,1973; Chapman and others , 1975). These anomalies are believed to represent dense, metamorphic, Franciscan rocks, such as those described by Blake and others (1967). Although structural unit 3 does not extend northeast to the Coast Range thrust in this area (McLaughlin, 1978), this unit might be present, at depth, adjacent to the thrust. If so, this would help explain the areal extent of the local, positive gravity anomaly.

A second gravity anomaly of particular interest is a negative anomaly, or series of anomalies, closely paralleling and located just southwest of the positive metamorphic anomaly. The negative anomaly is within McLaughlin's structural unit 2, and it is just northeast of and approximately parallel to structural unit 1 shown on Plate VII and Figure 9 (McLaughlin, 1978). The anomaly extends from southwest of Highland Springs (Sec. 31, T. 13N., R. 9W.), southeastward to near Mt. St. Helena. Part of The Geysers Geothermal field is within the anomaly.

Isherwood (1975) and Denlinger (1979) have suggested that this negative anomaly, or part of it, represents the geothermal field, because the steam reservoir should have a relatively low density. However, an examination of the negative anomaly in Figure 9, compared with the outline of The Geysers Geothermal field (Smith and others, 1978), indicates a poor correlation. For example, the negative gravity anomaly extends to the northwest for at least $40 \mathrm{~km}$ ( 25 miles), a much greater length than the known (or likely) extent of the field. Furthermore, the geothermal field is largely northeast of the anomaly.

Because the anomaly trend coincides with the regional geologic structure in the area, I believe the primary cause of the negative gravity anomaly is a geologic unit, perhaps melange, in McLaughlin's (1978) structural unit 2. The geothermal field or zones of altered rock may contribute to the parts of the anomaly with higher amplitude (greater than -2 mgal), but even these are mostly outside of the geothermal field, and, therefore, may have other causes.

A small, positive, gravity anomaly with a maximum amplitude of about 4 mgal,trending northwesterly, crosses the northern part of the geothermal field from the vicinity of Sec. 20, T. 11N., R. 8W. to Sec. 3, T. 11N., R. 9W. (Plates VI and VII). On Plate VII, the anomaly tends to merge with the larger metamorphic anomaly to the northeast, but, on Plate VI, the anomaly can be seen within the southwestern closure of the main negative anomaly. The anomaly apparently is associated with a relatively thick greenstone unit (McLaughlin, 1978). A well in Sec. 18, T. 11 N., R. 8W., on the trend of this anomaly, was drilled into greenstone with an apparent thickness of $1885 \mathrm{~m}$.

\section{Steam Reservoir Calculations}

R.P. Denlinger (1979) has designed a model for the steam reservoir in the area of The Geysers Geothermal field. The reservoir has a calculated volume of $100 \mathrm{~km}^{3}$ and a density contrast of from $-0.04 \mathrm{~g} / \mathrm{cm}^{3}$ to $-0.06 \mathrm{~g} / \mathrm{cm}^{3}$. The model is based on a residual negative gravity anomaly of 3 to 5 mgal remaining after removal of the effect of a sphere of partially molten rock (lsherwood, 1975 p. 33). The hypothetical reservoir extends from near the surface to about $3 \mathrm{~km}$ in depth. The density contrast is assumed to be due, largely, to steam displacing water in a pore volume of 4.5 percent. Therefore, the cause of the negative anomaly is attributed to high temperatures, steam-filled pores, and fracturing within the reservoir (Denlinger, 1979).

This estimate of reservoir size must be considered speculative because the computed size of the reservoir is heavily dependent on the size of the residual gravity anomaly, which, in turn, is dependent on the model assumed for the deep source. Furthermore, the anomaly might represent a melange unit, as discussed previously.

One of the chief problems in the analysis is the assumption that the source of the main anomaly is a spherical mass. Figure 8 shows that the gravity anomaly caused by a single sphere apparently is inadequate to satisfy the observed gravity anomaly, which is strongly asymmetrical in profile. A large residual anomaly will result if the anomaly for the spherical source in Figure 8 is removed from the observed data. However, it is not difficult to construct a model that results in a very small residual anomaly or even the complete absence of one in the area of The Geysers Geothermal field. The tilted cylindrical source is one such possible model (Fig. 8).

\section{Reservoir Interpretation from Gravity and Geodetic Changes}

When a net loss results from removing geothermal fluids out of a reservoir such as The Geysers, the result is a mass deficit over a period of time. The deficit, in theory, can be measured with repeated, precise, gravity measurements. Isherwood (1977) made such measurements in the area of The Geysers Geothermal field from 1974 to 1977. Lofgren (1981) measured geodetic strain at the same time.

After correcting the gravity measurements for elevation changes, Isherwood (1977) found decreases of gravity at most stations and a fairly broad maximum negative gravity change of about 120 microgals near the center of the steam production area. Analysis of these data indicates that (1) the gravity changes are too large to be due solely to a deep water table below the producing zone penetrated by the wells, and (2) the gravity flux implies a mass deficiency equal to the mass produced, suggesting negligi- 


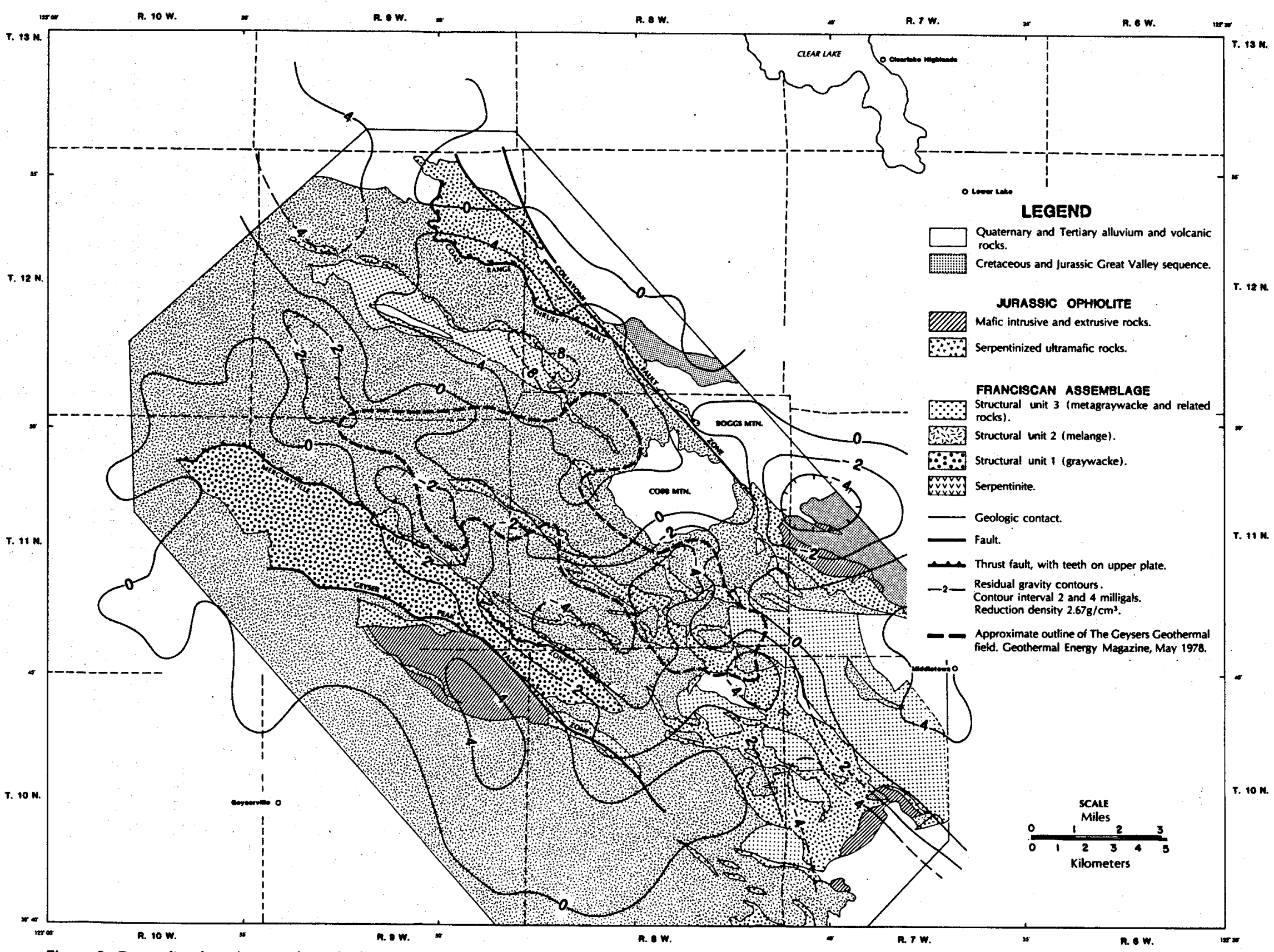


ble recharge (Isherwood, 1977). Also, mapped values of maxima in subsidence, gravity change, and pore pressure decline, overlap in the steam production area (Denlinger and others, 1979, Fig. 7).

Because of the lack of a measurable temperature change in the reservoir from 1974 to 1977 (plus or minus 3 degrees Celsius), the amount of water that flashed to steam during production was limited to less than 0.5 percent of the bulk rock volume (Denlinger and others, 1979). Based on this constraint, the maximum mass change of the bulk reservoir volume is $0.004 \mathrm{~g} / \mathrm{cm}^{3}$. Denlinger and others (1979), working from measurements of the net loss of mass from the geothermal field, calculated a volume of between 15 and 25 cubic $\mathrm{km}$ from which liquid water was depleted from 1974 to 1977.

Denlinger and others (1979) also modeled the surface geodetic data. They determined that the strain values were between $3 \times 10^{-5}$ and $8 \times 10^{-5}$ for the drainage volumes mentioned in the previous paragraph, and that the strain could be induced either mechanically or thermally. They concluded it was not possible to know the cause without additional information.

Thus, it appears that, with time, changes in the gravity field, when combined with geodetic and other measurements, may be useful for determining reservoir characteristics during the productive life of a geothermal field. For example, it may be possible to estimate the productive lifetime of a steam reservoir.

An experiment with a cryogenic gravity meter was carried out at The Geysers Geothermal field in 1979 (Olson and Warburton, 1979). The meter was installed on a concrete pier on bedrock at a site within the geothermal field. The cryogenic gravity meter is essentially drift-free, and the data have a precision of 1 microgal once corrections are made for earth and ocean tides and for atmospheric. density variations.

The results of a 38 day test of the cryogenic gravity meter show short-term effects that have been correlated by Olson and Warburton (1979) with local small earthquakes and a period of significant rainfall. In addition to the short term effects, the data show a general decrease in residual gravity of $4.5 . \pm 0.5$ microgals over the 38 day period. Extrapolation of this trend yields a rate of decrease in gravity of $43 \pm 5$ microgals per year, which is in close agreement with the average rate of decrease of $46 \pm 7$ microgals per year from Isherwood's (1977) data. Use of the cryogenic gravity meter may yield data on reservoir characteristics, such as recharge, over a relatively short period of time.

\section{MAGNETIC DATA}

\section{Aeromagnetic Maps}

Aeromagnetic maps of The Geysers Geothermal field area have been published by the CDMC (Chapman, 1975, p. 13) and by the U.S. Geological Survey (1973). The CDMG survey was flown at a flight elevation of $1,981 \mathrm{~m}$ $(6,500)$ feet, with a flight line spacing of approximately $5 \mathrm{~km}$ ( 3 miles). The map was compiled at a scale of $1: 250,000$, but published at a scale of about $1: 470,000$.
The U.S. Geological Survey map was flown at a flight elevation of $1372 \mathrm{~m}(4,500$ feet $)$ with a line spacing of $1.6 \mathrm{~km}$. $(1$ mile). This map was published at a scale of 1:62,500.

Because of the line spacing and scale, the U.S. Geological Survey aeromagnetic map of The Geysers area is the more useful of the two maps (Plate VIII). Isherwood (1975, p. 10-18) and Chapman (1975, p. 10-15) have concluded that the magnetic anomalies in The Geysers area are caused chiefly by serpentinized ultramafic rocks, and, to a lesser extent, by units of the Clear Lake Volcanics.

The Geysers Geothermal field is largely within a northwest-trending, magnetic low area. This is probably because the low area is between two approximately parallel, high magnetic anomalies related to serpentinized ultramafic rocks northeast and southwest of the geothermal field. The low area may be caused, in part, by hydrothermal alteration of magnetite in rocks within and near the geothermal area. Studies of the data, however, show no evidence that the geothermal field area is characterized by a unique magnetic anomaly.

\section{Ground Magnetic Profile}

In 1968, the CDMG made a ground magnetic traverse from near Jimtown in the Alexander Valley, northeast through The Geysers to Clear Lake along roads and trails (Fig. 10 and Plate $\mathrm{VI}$ ). A Jalander fluxgate magnetometer was used for the survey.

The ground profile shows the same overall features as the aeromagnetic map. Near the south end of the profile, a magnetic high may be caused, at least in part, by the serpentinite near Geyser Peak (Secs. 27 and 34, T. 11N., $R$. $9 W$.). To the north is a magnetic low near Mercuryville (Sec. 25, T. 11N., R. 9W.) that extends northward through The Geysers area.

The magnetic low is bounded on the north by a magnetic high related to the serpentinite, marking the location of the Collayomi fault zone (and Coast Range thrust) just southwest of Glenbrook (Sec. 33, T. 12N., R. 8W.). Immediately north of the Collayomi fault high is a negative anomaly that may be associated with the adjacent high.

The next anomaly is a magnetic high southeast of $\mathrm{Mt}$. Konocti. The anomaly might be caused by volcanic rocks within the Clear Lake Volcanics, or, possibly, by serpentinite in the underlying Franciscan rocks. Near the end of the profile, on the southwestern edge of Clear Lake, values indicate a magnetic low that is also on the aeromagnetic map. However, the anomaly may be a negative feature that often appears on the northern side of a strong magnetic high.

\section{ELECTRICAL RESISTIVITY DATA}

Plate IX is a composite apparent resistivity contour map of parts of The Geysers-Clear Lake area. Data for most of the Clear Lake Volcanics area and for the eastern part of The Geysers Geothermal field were taken from the U.S. Geological Survey report by Stanley and others (1973). Data for the central part of The Geysers Geothermal field and an area extending from near Tyler Valley (Sec. 19, T. 


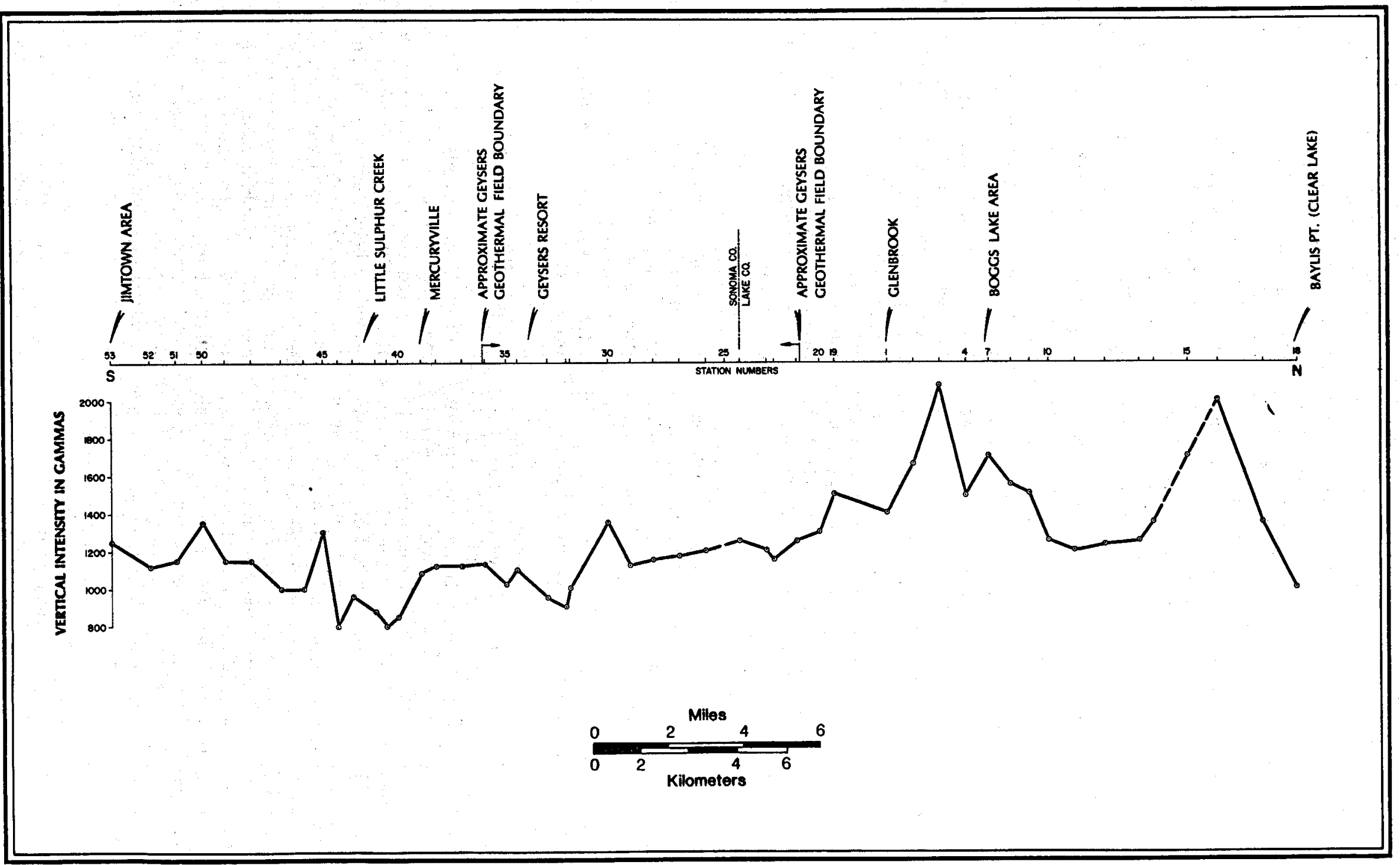


12 N., R. 9W.) to west of Highland Springs were from an anonymous source.

The resistivity data are the result of bipole-dipole (or total field dipole) reconnaissance measurements. Plate IX shows the locations of the source bipoles and the receiver dipoles. It is apparent from the length of the source bipoles and the distribution of receiver stations shown on Plate IX, that the U.S. Geological Survey study utilized longer bipoles and probably higher power than the other survey. As a result, the U.S. Geological Survey study's depth of investigation was probably greater, but the other survey obtained more detail within the area of its investigation. The two maps overlap somewhat in one area, northeast of The Geysers.

The two maps compiled on Plate IX actually consist of a compilation of smaller maps, each made from one position of a source bipole. These maps are compiled by smoothing and joining contours to give the most reasonable fit. Plate IX also shows the locations of a number of Schlumberger vertical electric soundings (VES) made by the U.S. Geological Survey. These were made to measure the change, with depth, of the apparent resistivity.

On Plate IX, the 5 ohm-meter contour in the central part of the map defines a large, low-resistivity anomaly, extending from the vicinity of Mt. Hannah on the northwest to Boggs Mountain on the southeast. The anomaly is closely bounded on the west by the Collayomi fault. This low-resistivity anomaly is nearly coincident with the central part of the large negative gravity anomaly shown in Plate VI.

The coincidence suggests a common source for both anomalies, perhaps the probable magma chamber that underlies the area (as suggested by the gravity data) and associated, hot, mineralized water. Goff and others (1977), however, have suggested that the low resistivity in the vicinity of Mt. Hannah is caused, in part, by the presence of Great Valley sequence rocks, characterized by high-chloride connate waters below the young volcanic cover.

Figure 11, modified from Stanley and others (1973, Fig. $8)$, is an interpreted section along five VES stations in a line from Boggs Lake (Sec. 17, T. 12N., R. 8W.) on the west, to the vicinity of the town of Lower Lake on the east (Plate IX). The profile crosses the large, low-resistivity anomaly discussed previously. The rock unit responsible for the low-resistivity anomaly (about 2.5 ohmmeters) may be $4572 \mathrm{~m}$ (15,000 feet) thick, east of Mt. Hannah. It underlies two, near-surface rock units of higher resistivity (500 and $25 \mathrm{ohm}$-meters respectively).

Southwest of the Collayomi fault, small, low-resistivity anomaly closures that locally are as low as 2 ohm-meters are shown on Plate IX near Castle Rock Springs (Sec. 26, T. 11N., R. 8W.), west of The Geysers Resort, and west and southeast of Tyler Valley. The anomalies at Castle Rock Springs and The Geysers Resort are within The Geysers Geothermal field.

McLaughlin and Stanley (1976) interpret the anomaly in the Castle Rock Springs area as indicating conductive fluid in the crest of a local structural high. However, the map showing contours on the top of the main graywacke unit does not indicate a structural high in the Castle Rock Springs area (Plate II). The resistivity anomaly west of The
Geysers Resort that extends generally northeastward to . the vicinity of Power Plant 17 (Sec. 7, T. 11N., R. 8W.), and the anomaly at Castle Rock Springs, correspond in general to areas of high top of first steam entry (Plate IV). These, and other similar anomalies, may represent relatively near-surface conductive fluids or areas of extensive rock alteration.

Drilling apparently has not revealed commercial steam at the anomalies northwest of The Geysers Geothermal field. Thus, this type of low-resistivity anomaly is not necessarily indicative of underlying steam reservoirs. In fact, much of The Geysers Geothermal field is apparently characterized by intermediate-to-high apparent resistivities (Plate IX). However, electric logs generally show low-to-intermediate values of electrical resistivity (25-50 ohm-meters) in the rocks above the steam reservoir.

A comparison between the resistivity data (Plate IX), and residual gravity (Plate VII), reveals some local correlations between resistivity anomalies and local gravity anomalies. For example, a small gravity high (4 mgal) closely corresponds with a resistivity high (20 ohm-meters) in the vicinity of Howard Springs (the Howard Springs arch) (Sec. 30, T. 12N., R. 7W.). Also, a gravity high (10 mgal) corresponds with a local resistivity high (300 ohm-meters) near the southeastern end of Clear Lake. These anomalies may be caused by relatively dense and resistive Franciscan rocks near the surface (Goff and others, 1977).

Small, negative gravity anomalies at Castle Rock Springs and near The Geysers Resort correspond, in part, to the low resistivity anomalies in those locations. These gravity and resistivity anomalies, as well as a negative gravity anomaly and some of the low-resistivity anomalies near Tyler Valley, could be caused by a combination of nearsurface hot water and the steam zone, or, perhaps, by extensive rock alteration resulting in lower density and lower electrical resistivity.

\section{AUDIO-MAGNETOTELLURIC DATA}

The audio-magnetotelluric (AMT) technique is an electromagnetic sounding method that, except for some of the higher frequencies, utilizes natural sources from about 7.5 $\mathrm{Hz}$ to $20,000 \mathrm{~Hz}$. In geothermal exploration, the AMT method has been used, chiefly, as a reconnaissance technique because the method is particularly useful for locating conductive zones caused by hot, saline waters. The depth penetration of the method is limited to shallow depths in areas of low, near-surface resistivity, making the method most useful where there is a high resistivity cover. For this reason, and also because of federal leasing activity in the area, the stations used by the U.S. Geological Survey (Plate IX) were outside of low resistivity areas.

Most of the eight AMT stations (Long and Senterfit, 1976) are in the area southeast of Castle Rock Springs (Plate IX). Two soundings were made at each site, one with the telluric line oriented north-south, the other with the telluric line oriented east-west. A total of 9 frequencies (from $7.5 \mathrm{~Hz}$ to $18,600 \mathrm{~Hz}$ ) were used for the measure- 


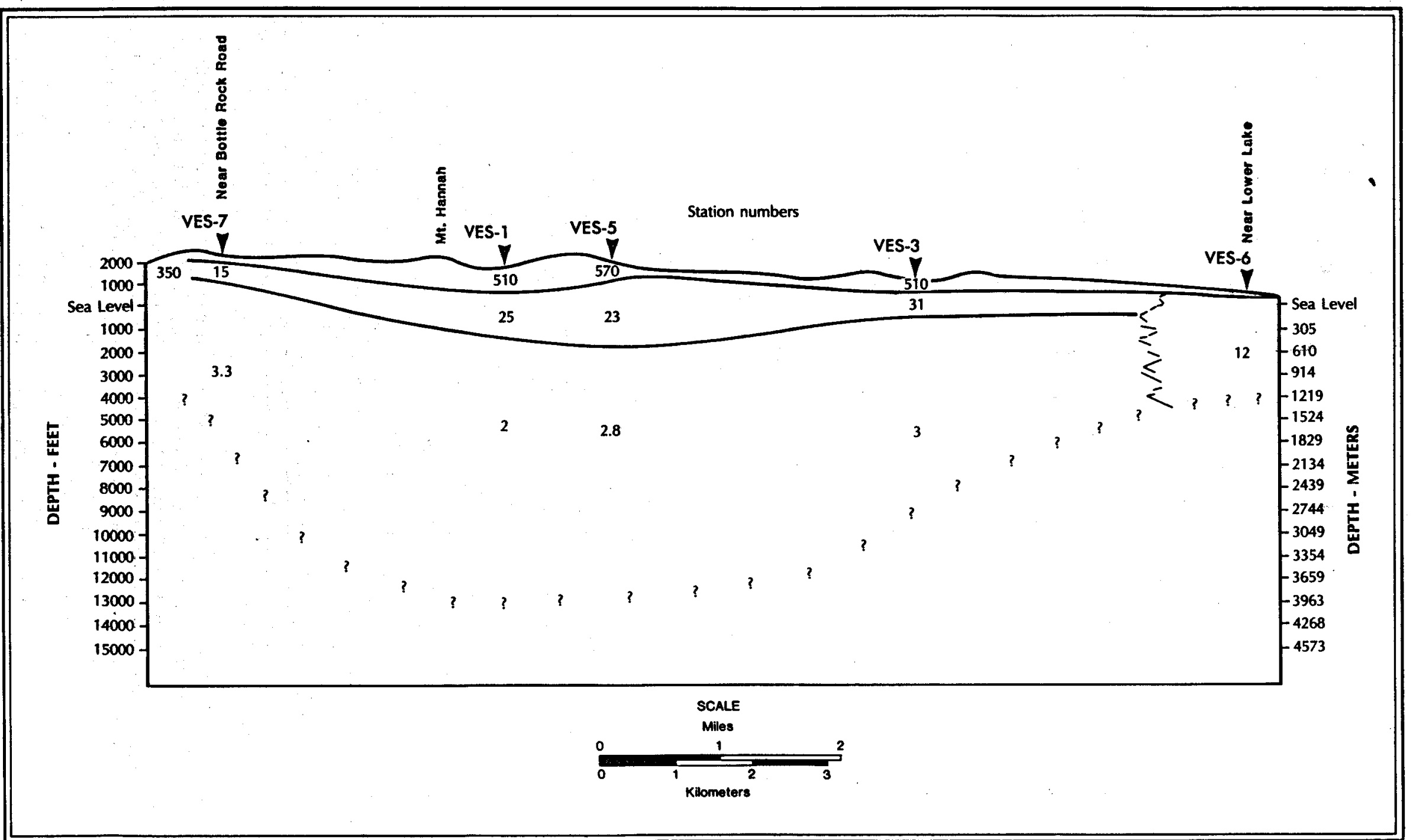




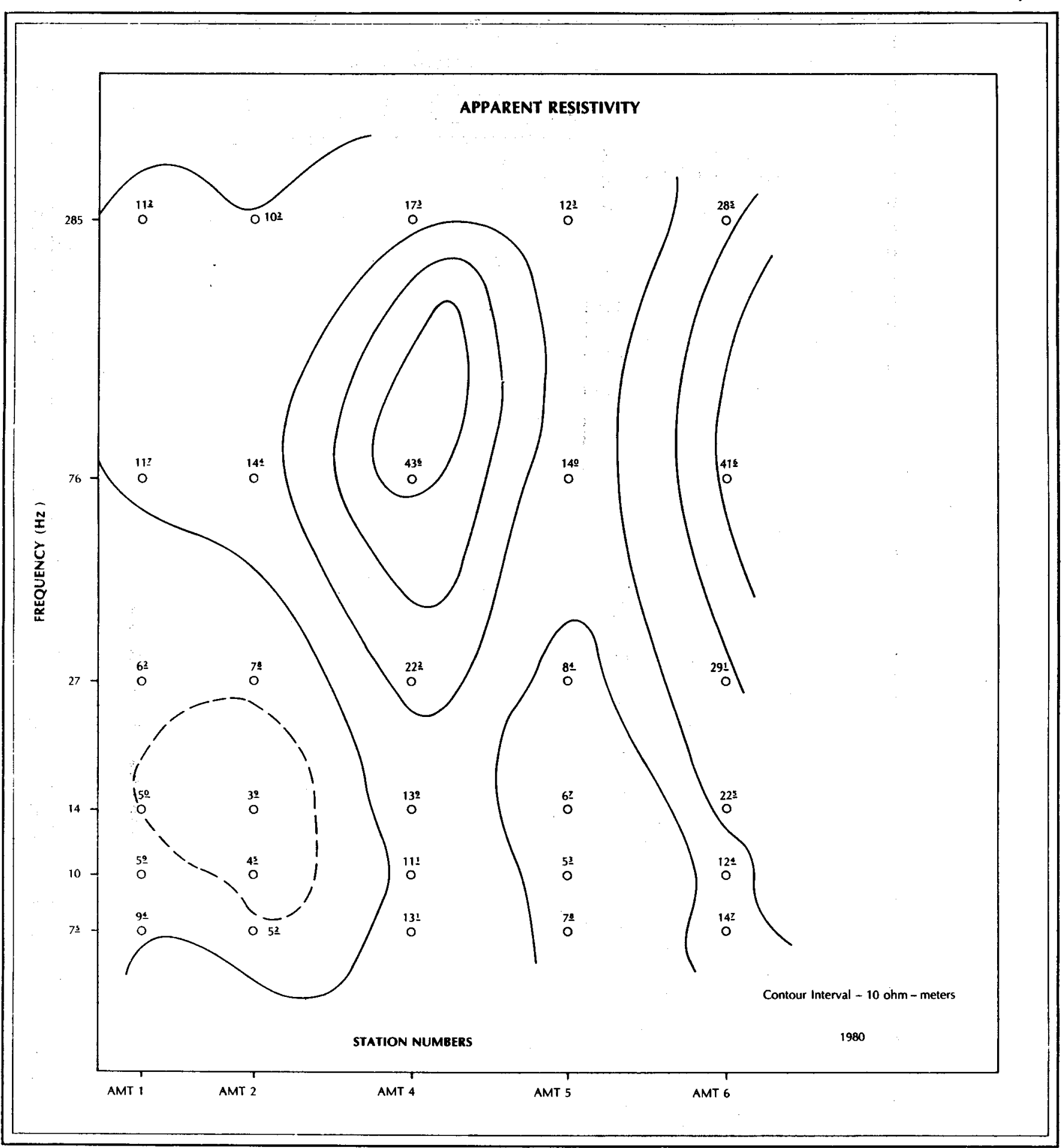

Figure 12. Pseudosection, audio-magnetotelluric data, west-east component. See Plate IX for location. Basic data from U.S. Geological Survey Open-File Report 76-7000.

ments. Figures 12 and 13 show apparent resistivity contours in the form of pseudo-sections for the E-W and N-S data, respectively, from five of these stations $(1,2,4,5$, and 6) that form a northwest-trending line (Plate IX). Data on these figures are plotted with the values of frequency decreasing from the top of the figures downward, because the lower the frequency, the deeper the section represented by the corresponding apparent resistivity.

Figures 12 and 13 indicate relatively low apparent resis- tivities at stations 1 and 5 . On the E-W data section (Fig. 12), the low resistivity in the deeper portion of the section extends beneath station 2 . The three highest frequencies recorded (not plotted in Figs. 12 and 13) show some indication of higher apparent resistivities in the shallower parts of the section.

In general, the apparent resistivity values from the stations in The Geysers area are low, indicating a shallow depth of penetration. For example, the maximum penetra- 


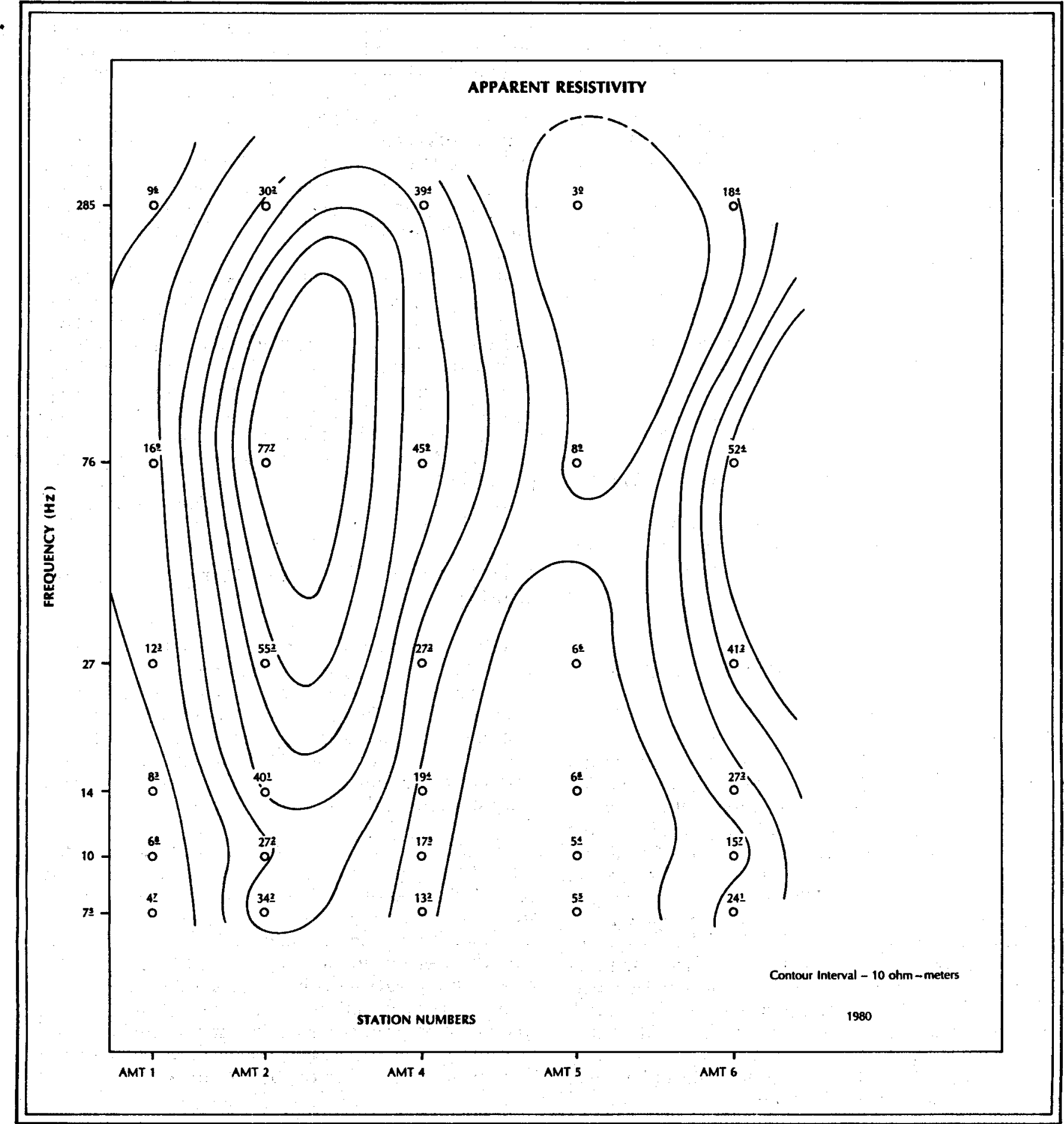

Figure 13. Pseudosection, audio-magnetotelluric data, north-south component. See Plate IX for location. Basic data from U.S. Geological Survey Open-File Report 76-7000.

tion may be above the top of the steam zone at Castle Rock Springs, which is at a depth of 300 meters or more. The low measured resistivities suggest the presence of hot, mineralized water or, possibly, extensive rock alteration over much of the area. The resistivity values are also within the range of those shown by bipole-dipole measurements in the same area (Plate IX).

\section{TEMPERATURE MEASUREMENTS AND HEAT FLOW}

Temperature profiles in two wells within The Geysers Geothermal field reported by Urban and others (1976), are nearly linear to the maximum depth logged $(0.8 \mathrm{~km})$. Extrapolations of measured hole temperature down to the 
depth of the steam reservoir yield a temperature close to that of the reservoir $\left(240{ }^{\circ} \mathrm{C}\right)$. These facts indicate that heat transport between the steam reservoir and the surface is by conduction (Urban and others, 1975). A comparison by these authors of the observed temperature profiles, with models calculated on the basis of conductive heat flow, indicates that the steam reservoir is at least several thousand years old and, quite possibly, much older.

Calculations of heat flow for the two wells at The Geysers yield values between 7.5 and $9.3 \mathrm{hfu}$ (heat flow units) (Urban and others, 1975). Heat flow in a well near Cloverdale, about $13 \mathrm{~km}$ west of The Geysers, is anomalously high (approximately $4 \mathrm{hfu}$ ) with respect to the regional heat flow (about $2 \mathrm{hfu}$ ). According to Urban and others (1975), the high heat flow at Cloverdale suggests that anomalous conditions may extend far beyond the area of the geothermal field.

Jamieson (1976) studied temperature gradients and heat flow in an area that includes the northwestern part of The Geysers Geothermal field. He concluded that high heat flow in The Geysers area is consistent with the presence of a hot intrusive mass (about $700^{\circ} \mathrm{C}$ ) at a depth of about $8 \mathrm{~km}$ ( 5 miles). He also concluded that heat flow from this source to the surface is primarily by conduction, but that heat is transferred by convection within the geothermal reservoir and along fracture zones in the rocks overlying the reservoir.

\section{SEISMOLOGICAL INVESTIGATIONS}

\section{Microearthquake data}

Lange and Westphal (1969) were the first investigators to publish a microearthquake study of the area of The Geysers Geothermal field. After recording 19 small earthquakes in a 120 hour period in 1968, they concluded that these events occurred within the geothermal field and were predominantly along the Sulphur Creek fault zone.

Hamilton and Muffler (1972) reported on a more extensive survey in 1971 that detected 52 small earthquakes within $10 \mathrm{~km}$ of The Geysers field during a 3-week recording period. Most of these epicenters were in a zone about $4 \mathrm{~km}$ long and $1 \mathrm{~km}$ wide, that passes through the geothermal field along the trace of a principal fault zone. Both Lange and Westphal (1969) and Hamilton and Muffler (1972) concluded that microearthquakes might be characteristic of geothermal areas and, thus, might be useful in exploring for geothermal resources.

Additional microearthquake monitoring, reported by Bufe and others (1980), indicates a shallow seismogenic zone (limited to depths of $4 \mathrm{~km}$ to $5 \mathrm{~km}$ ) and a complex, diffuse pattern of faulting in the area. These reports also point out the consistency of the shallow seismogenic zone with elevated temperatures associated with a possible magma body at depth.

Majer and McEvilly (1979) found an absence of microearthquake activity within the main production zone at The Geysers (2-3km depth); however, Marks and others (1978, Plate I) and Ludwin and Bufe (1980) apparently did not observe such a distinct zone of low activity.
Marks and others (1978) correlate the microearthquake activity at The Geysers with the steam production areas, although Majer and McEvilly (1979) believe the microearthquake activity may be concentrated around the boundaries of the steam production areas.because of large temperature and pressure gradients there.

Both Marks and others (1978) and Majer and McEvilly (1979) suggest that the present seismic activity in the area of The Geysers Geothermal field is greater than the activity prior to steam production. They also note no correlations of microearthquake activity with through-going faults.

Some researchers feel the seismicity may be related to fluid withdrawal, and, possibly, to condensate injection, because the microearthquakes can be correlated with two pressure sinks in the geothermal field associated with the regions of steam production (Marks and others, 1978, Plate I; Ludwin and Bufe, 1980). Therefore, it is thought seismicity may be used to monitor the steam zone configuration as it changes during production. However, the value of microearthquake studies for locating either unexploited parts of the known geothermal field or possible new geothermal fields may be questioned, at least in the area of The Geysers Geothermal field.

\section{Teleseismic P-Wave and Refraction Seismic Studies}

Seismic data from teleseisms (lyer and others, 1979) and from explosion sources (Warren, 1981) indicate rock beneath The Geysers area with a lower seismic velocity than rock in other parts of the Coast Ranges. Teleseismic P-wave delays of 1 to 1.5 seconds at some stations in the area near Mt. Hannah and the geothermal field show a subsurface velocity decrease of 25 percent that extends to a depth of $20 \mathrm{~km}$ or more.

On the basis of seismic refraction data, Majer and McEvilly (1979) conclude that the top $3 \mathrm{~km}$ of the crust beneath the area of The Geysers Geothermal field is not abnormally low in seismic velocity in comparison with the surrounding rocks. In fact, according to these investigators, The Geysers area is characterized by anomalously high $P$ and $S$ wave velocities, a low value of Poisson's ratio, and a low attenuation. In order to explain these data, lyer and others (1979) conclude that a magma chamber containing at least partially molten rock underlies The Geysers area at a depth of about $4 \mathrm{~km}$.

\section{Seismic Reflection Data}

The results of a seismic reflection survey in the Castle Rock Springs area have been described by Denlinger and Kovach ( 1981 ). The purpose of the survey was to determine the feasibility of using modern seismic reflection techniques to detail subsurface fracture zones from which steam in the area is produced.

The reflection survey was done by a contractor, Western Geophysical, with four Vibroseis* trucks and standard field procedures. The seismic survey consisted of two

\footnotetext{
- Vibroseis is a trade name for a patented process.
} 
lines nearly normal to each other (Plate VI). Standard data processing techniques were used, and velocities were upgraded as the data evaluation progressed.

According to McLaughlin and Stanley (1976), steam production in the Castle Rock Springs area is associated with an anticlinal warp in eastward-dipping metagraywacke and shale, interlayered with serpentinite and greenstone, although Plate II in this report does not show such a structure. McLaughlin and Stanley (1976) infer that folding-induced fracturing could increase permeability and form structures that might trap upward migrating geothermal fluid. The orientation of the fractures in the top of the anticline would tend to be subhorizontal, providing a target for the reflection method.

Comparison of the seismic data with well logs indicates that primary reflection events could be correlated with large, localized changes in the amount of fracturing with depth. The data also indicate that the seismic velocities are less sensitive to lithology than to the degree to which the rock units are fractured. It was concluded that thick, laterally continuous, undersaturated fracture zones produce strong seismic reflections.

Thus, seismic reflection techniques are promising as an exploration tool in The Geysers Geothermal field area and in other vapor-dominated geothermal fields. In addition to the shallow reflections, several deep reflections $(3.7 \mathrm{~km}$ and greater) were observed. These might be major tectonic boundaries in the Franciscan rocks, and could also act as pathways for mass transfer of heat from the heat source into the geothermal field.

\section{CONCLUSIONS}

Geophysical surveys performed in the area of The Geysers Geothermal field have contributed greatly toward understanding the geology of that part of the northern Coast Ranges. There is general agreement that the geophysical data show evidence for the existence of both the hot water part of the geothermal field and the underlying heat source. Less certainty exists concerning whether or not any of the surveys (except the microearthquake sur- veys) show evidence to establish the presence and location of the steam reservoir or to distinguish it from the hot water reservoir.

The interpretation of some geophysical surveys is controversial; for example, the occurrence of microearthquakes characterizes the present steam production area, but some investigators consider it doubtful that this condition existed prior to the development of the field. The pattern of microearthquake activity does not seem to indicate any possible extensions of the steam reservoir or any separate reservoirs that might exist in the area. Also, some investigators believe that residual gravity anomalies represent the geothermal field. However, the correlation between the anomalies and the geothermal field is poor, and these anomalies might be caused by other rock units in the area.

Gravity data, P-wave delay times, heat flow data, and possibly deep electrical soundings provide evidence of the presence of a heat source underlying The Geysers area. Reconnaissance electrical resistivity surveys have also shown large areas of low electrical resistivity that evidently represent zones of hot water or rock alteration in the same general area as the heat source. The lowresistivity anomalies occur in places near The Geysers Geothermal field, including parts of the steam reservoir near The Geysers Resort and the Castle Rock Springs area. However, they do not characterize the steam reservoir area as a whole. Thus, these methods show areas generally favorable for possible steam zones, but the areas are much larger in extent than the known reservoir.

Although seismic refraction data are of doubtful value for studies of the geothermal field, seismic reflection data offer promise as a means of detecting subhorizontal fracture zones that may serve as conduits for steam.

Monitoring gravity and geodetic changes in The Geysers area, although of no value in prospecting for steam, is a promising technique for determining reservoir size, possible recharge, production lifetime, and other characteristics. Similarly, microearthquake data may be useful for monitoring changes in steam zone configuration as the field is produced. 
$\checkmark$ 


\section{RESERVOIR ASSESSMENT}

\section{PREVIOUS STUDIES}

In 1970, Ramey" reported on the wells "Thermal" 1 to 14 near the Geysers Resort area (Plate I). He showed that the reservoir was underpressured with respect to hydrostatic pressure, and that the temperature varied very little with depth below $305 \mathrm{~m}(1,000$ feet $)$. He concluded that the steam reservoir could not be subject to significant water influx from water-bearing formations communicating with surface waters.

Ramey also published 1957-1967 production and pressure data (Table 2 ). He calculated a material balance (treating the steam reservoir as a gas field ) by plotting the $p / z$ of the steam versus cumulative production. From the plot, he calculated the initial mass of steam in place to be $109 \mathrm{Gkg}$ (241 billion pounds) in the Big Geysers area.

Ramey briefly reviewed the Sulphur Bank and Happy Jack areas (Plate I). The pressure buildup tests indicate that wells in the area have a lower permeability-thickness product than wells in the Big Geysers area. Ramey showed that, in 1967, the average, shut-in wellhead pressure drop for 4 Happy Jack wells was $0.7 \pm 0.14$ bars (10 \pm 2 psi) and for 11 Sulphur Bank wells was $2 \pm 1.4$ bars (29 \pm 20 psi). During 1967, 6 Sulphur Bank wells, but no Happy Jack wells, were on production. The decrease in pressure in the Happy Jack area indicates its reservoir connection with the Sulphur Bank area.

A short engineering study by Lipman and others (1977), was written when 11 power plant units were operating at The Geysers. The authors described a shallow steam anomaly into which the early wells were drilled. The anomaly had a pressure significantly lower than the pressure of the deeper, more extensive steam reservoir in other areas of the field. There was a definite gradient in original pres sure from the anomaly center (connected directly to the deeper reservoir) towards the edge, where pressures were lower by about 27.6 bars ( 400 psi).

In the Lipman study, pressure versus temperature plots fell closely along the saturation curve for water, indicating the reservoir contained saturated steam.

The report included an isobaric map of the regional system, illustrating how the 34.5 bars (500 psia) isobar

\footnotetext{
${ }^{A}$ Bibliographical data for references in this chapter are in the Reservoir Assessment section of the list of Selected References at the end of the report.
}

moved outward, with time, as production continued. An isobaric map as of April 1977 was also published, showing the pressure gradient within the pressure sinks. The two maps cover the area where wells produced steam for power plant Units 1 through 11. However, the authors did not present production data to correlate with the pressure behavior.

Individual, wellhead pressure behavior was included for two shut-in wells. Well "Cobb Mountain" 1 (Plate I), near Units 1, 2, 9, and 10, showed a wellhead pressure decline from 32.9 bars gauge (477 psig) in 1971 to 26.8 bars gauge (388 psig) in 1977. During this time, power plant Units 5 through 11 were placed on line. The pressure decline for well "CMHC" 1 indicates that the reservoir is connected to the wells supplying steam to Units 1, 2, 9, and 10.

Well "Lakoma Fame 4597" 1, slightly over 2 miles from power plant Units 1 and 2, showed no decrease in wellhead pressure from 1970 to 1973 . This was not unexpected; based on the rate of growth of the 34.5 bars ( 500 psi) pressure isobar of less than $305 \mathrm{~m}(1,000$ feet) per year, as shown by Lipman and others. With this growth rate, it would have taken about 10 years for the effect to be felt at "Lakoma Fame 4597" 1.

Table 2. Big Geysers area shallow zone cumulative production and reservoir pressure, 1957-1967, The Geysers Geothermal field (Ramey, 1970). This table excludes production from original wells, drilled in the 1920's, and production from wells T-8, $T-13$, and $T-14$ after completion in the deep zone.

\begin{tabular}{|c|c|c|c|c|c|c|c|}
\hline Year & $\begin{array}{l}\text { No. } \\
\text { Wells }\end{array}$ & $\begin{array}{r}\text { Steam } \\
\text { MM Ib./vr. }\end{array}$ & $\begin{array}{l}\text { oduced } \\
M \text { ib. } / \mathrm{hr} \text {. }\end{array}$ & $\begin{array}{l}\text { Cumulative } \\
\text { Steam } \\
\text { MM B. }\end{array}$ & $\begin{array}{l}\text { Avg. Res. } \\
\text { Pressure } \\
\text { psia, measured } \\
\text { at the wellhead }\end{array}$ & $z$ & $\mathbf{P} / \mathbf{Z}$ \\
\hline 1957 . & 0 & 0 & 0 & 0 & 194 & 0.913 & 212 \\
\hline 1957 & 5 & 1109.8 & 126.7 & $1,109.8$ & 187 & 0.915 & 204 \\
\hline 1958 & 5 . & 3224.4 & 368.1 & $4,334.2$ & 180 & 0.917 & 19 \\
\hline 1959 & 10 & 3426.7 & 391.2 & $7,760.9$ & 174 & 0.919 & 109 \\
\hline 1960 & 10 & 4698.2 & 536.3 & $12,459,1$ & 169 & 0.921 & 183 \\
\hline 1961. & 10 & 4246.5 & 464.7 & $16,705.6$ & 164 & 0.922 & 178 \\
\hline 1962 & 10 & 4377.6 & 497.7 & $21,083.2$ & 160 & 0.923 & 173 \\
\hline 1963 & 13 & 5299.7 & .605 .0 & $26,362.9$ & 156 & 0.924 & 169 \\
\hline 1964 & 12 & 6197.5 & 707.4 & $32,580.4$ & 152 & 0.925 & 164 \\
\hline 1965 & 9 & 5509.9 & 629.0 & $38,090.3$ & 148 & 0.927 & 160 \\
\hline 1966 & 7 & 4941.4 & 564.0 & $43,031.7$ & 145 & 0.928 & 156 \\
\hline $1 \% 7$ & 7 & 3847.3 & 439.0 . & $46,879,0$ & 142 & 0.929 & 153 \\
\hline
\end{tabular}




\section{RESERVOIR DESCRIPTION}

\section{Rock Properties}

Mostly, The Geysers steam reservoir consists of massive, dense graywacke with low-to-no permeability. Decius (1961) estimated the graywacke to have a permeability of less than 1 millidarcy and a porosity of less than 10 percent. Lipman and others (1978), stated that core analysis on a limited number of samples indicate a porosity of 3 to 7 percent and air permeabilities normally below 1 millidarcy.

Because of the very low permeability, steam flows for wells are only obtained when open fractures are encountered during drilling. Information obtained from very limited field coring seems to indicate that the fractures are nearly vertical.* The number of fractures penetrated by a well, based on reported steam entries, varies from 1 to 17. The majority of the wells have 1 to 7 steam entries. Occasionally, a drilling break of a few feet occurs, indicating a large fracture or cavernous opening in the rock.

\section{Fluid Characteristics}

Wells at The Geysers produce slightly superheated steam at wellhead pressures ranging between 8.27 bars (120 psi) and 10.34 bars (150 psi). On an average, the steam contains less than 1 percent noncondensible gases, mainly carbon dioxide. The range of noncondensible gas concentrations and the average concentration, based on 61 samples, are in Table 3. Samples range from 0.12 to 3.4 weight percent of noncondensible gases in the steam, with an average of 0.40 percent.

Analysis of noncondensible gases for two steam samples from an Aminoil USA, Inc. well were published by Truesdell and others (1978), (Table 4). Although the two samples are chemically similar, they differ considerably from average sample concentrations published by Allen and McCluer (1976). This finding is to be expected because of the wide range on concentrations published by Allen and McCluer.

\section{Initial Reservoir Pressure and Temperature}

The initial pressure and temperature are important characteristics of a geothermal reservoir. In a steam reservoir, the initial pressure and temperature are closely allied by the saturation curve of water. A steam reservoir acts somewhat like a condenser, in that steam from boiling liquid at a deep level moves upward and is condensed as it contacts cooler rock.

Examples of static pressure and temperature surveys are in Figures 14 through 17. The wells were not totally shut in but were placed on bleed to keep them in a heated condition. The wells produced about $1,000 \mathrm{Kg} /$ $\mathrm{hr}$ (a few thousand pounds). The measured data should

* However, geologic cross sections prepared for this report indicate otherwise. Based, in part, on interpretations of these cross sections, Thomas, in the subsurface geology chapter, suggests that the subhorizontal-to-moderately dipping alignment of steam entries is indicative of laterally connected fractures.
Table 3. Noncondensible gases in steam from wells at The Geysers power plant (Allen and McCluer, 1976).

\begin{tabular}{|l|ll|r|}
\hline \multicolumn{1}{|c|}{ Gas } & \multicolumn{2}{|c|}{$\begin{array}{l}\text { Range of concen- } \\
\text { trations measured } \\
\text { (\% by weight) } \\
\text { Low }\end{array}$} & $\begin{array}{r}\text { High } \\
\text { Average } \\
(\% \text { by weight })\end{array}$ \\
\hline Carbon dioxide & 0.029 & 3.06 & $0.326 \star$ \\
Hydrogen sulfide & 0.0005 & 0.106 & $0.0222 \star$ \\
Methane & 0.0013 & 0.1447 & $0.0194 \star$ \\
Ammonia & 0.00094 & 0.106 & $0.0194 \star$ \\
Nitrogen & 0.0006 & 0.0638 & $0.0052 \star$ \\
Hydrogen & 0.0011 & 0.0218 & $0.0056 \star$ \\
Ethane & 0.0003 & 0.0019 & Negligible \\
Total noncondensibles & 0.120 & 3.41 & $0.398 \star$ \\
& & \multicolumn{3}{|c|}{} \\
$\star$ Average of 61 producing wells measured in 1972-1974. \\
\hline
\end{tabular}

only be applied to the reservoir opposite the open inter$\mathrm{val}$ in the wellbore. The pressure drop into the wellbore can probably be ignored as being no more than 0.14 bars (a few psi) except, perhaps, for wells that can produce only at a low rate.

Figure 14 contains the results of two surveys run about a year apart for Well $A$. The pressure measurements of the surveys differed by about 3.5 bars ( 50 psi). The dashed curves show the saturation temperature based on the measured pressure. For Run 1, there is excellent agreement between the measured temperature and the saturation temperature down to $914 \mathrm{~m}(3,000$ feet). Below this depth, the measured temperature increases more rapidly, until, at $2,134 \mathrm{~m}(7,000$ feet $)$, the measured temperature is $7^{\circ} \mathrm{C}\left(13^{\circ} \mathrm{F}\right)$ above the saturation temperature. The higher measured temperature could be caused by superheated steam flowing in the reservoir, but it is more likely caused by instrument error. The two temperatures closely agree for Run 2 , with the measured temperature being about $1.7^{\circ} \mathrm{C}\left(3^{\circ} \mathrm{F}\right)$ higher.

Well B static pressure and temperature measurements are in Figure 15. The well has a liquid level $366 \mathrm{~m}(1,200$ feet) below the lowest reported steam entry. The measured temperature and the saturation temperature closely agree.

Two runs about a year apart for Well $\mathrm{C}$ are in Figure 16. Although the pressures for the two runs closely agree, the measured temperatures differ greatly, with

Table 4. Analysis of noncondensible gas from an Aminoil well, The Geysers Geothermal field (Truesdell and others, 1978).

\begin{tabular}{|c|c|c|c|c|}
\hline \multirow[b]{2}{*}{ Gas } & & \multicolumn{3}{|c|}{ Mol percent in gas } \\
\hline & & Sample 2 & & Sample 3 \\
\hline \multicolumn{2}{|l|}{ Carbon dioxide } & 92.2 & & 94.4 \\
\hline \multicolumn{2}{|l|}{ Hydrogen sulfide } & 0.22 & & 0.10 \\
\hline \multicolumn{2}{|l|}{ Hydrogen } & 4.4 & & 3.5 \\
\hline \multicolumn{2}{|l|}{ Argon } & 0.003 & & 0 \\
\hline \multicolumn{2}{|l|}{ Nitrogen } & 0.57 & & 0.32 \\
\hline \multirow[t]{2}{*}{ Methane } & & 2.8 & & 1.9 \\
\hline & \multicolumn{4}{|c|}{$\begin{array}{l}\text { Mols per } 100 \text { mols water } \\
\text { in gas in cond. in gas in cond }\end{array}$} \\
\hline Carbon dioxide & 0.11 & 0.093 & 0.11 & 0.078 \\
\hline Hydrogen sulfide & $2.6 \mathrm{E}-4$ & 0.020 & $1.2 E-4$ & 0.020 \\
\hline
\end{tabular}




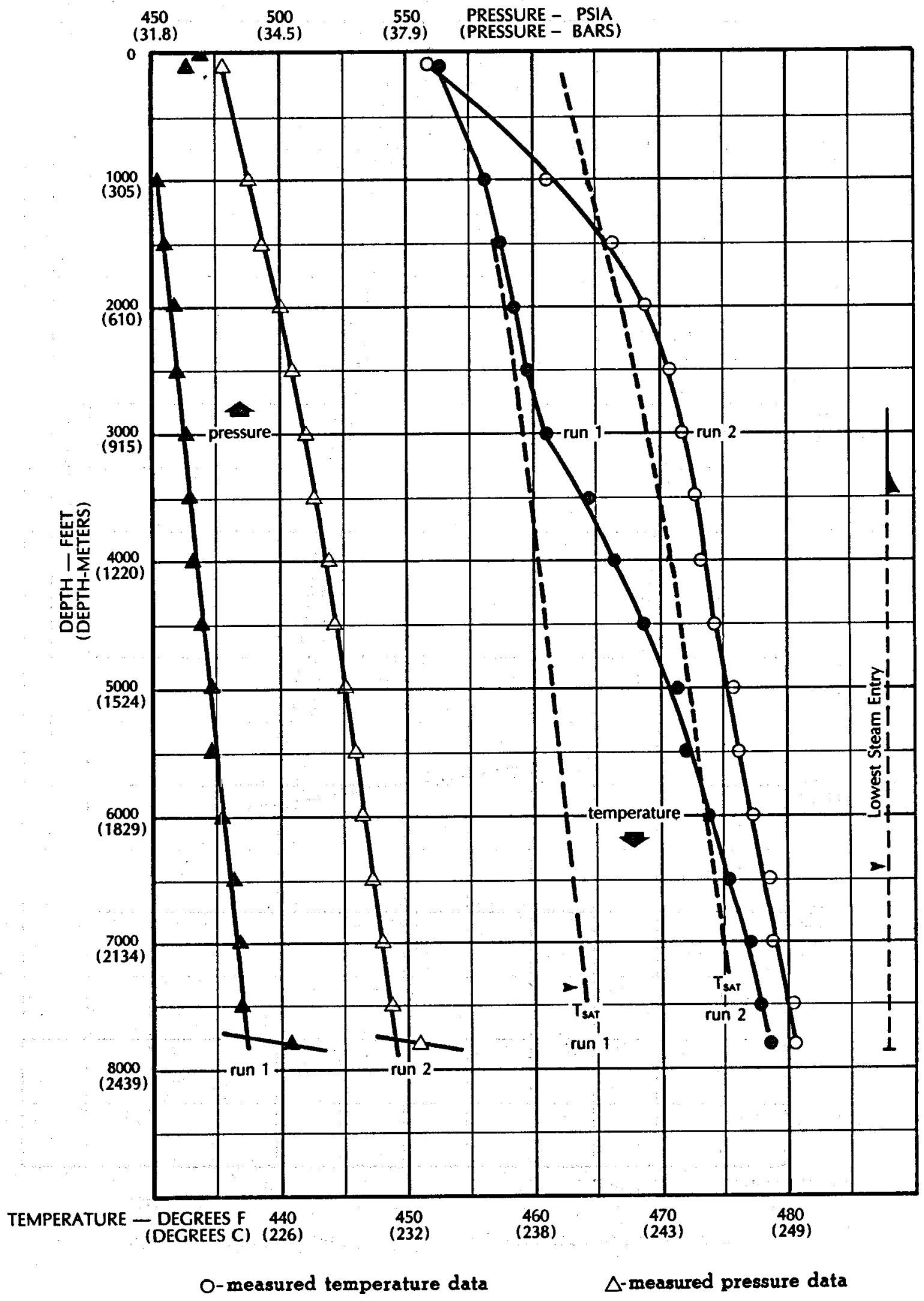

Figure 14. Static pressure and temperature surveys, Well $A$. 


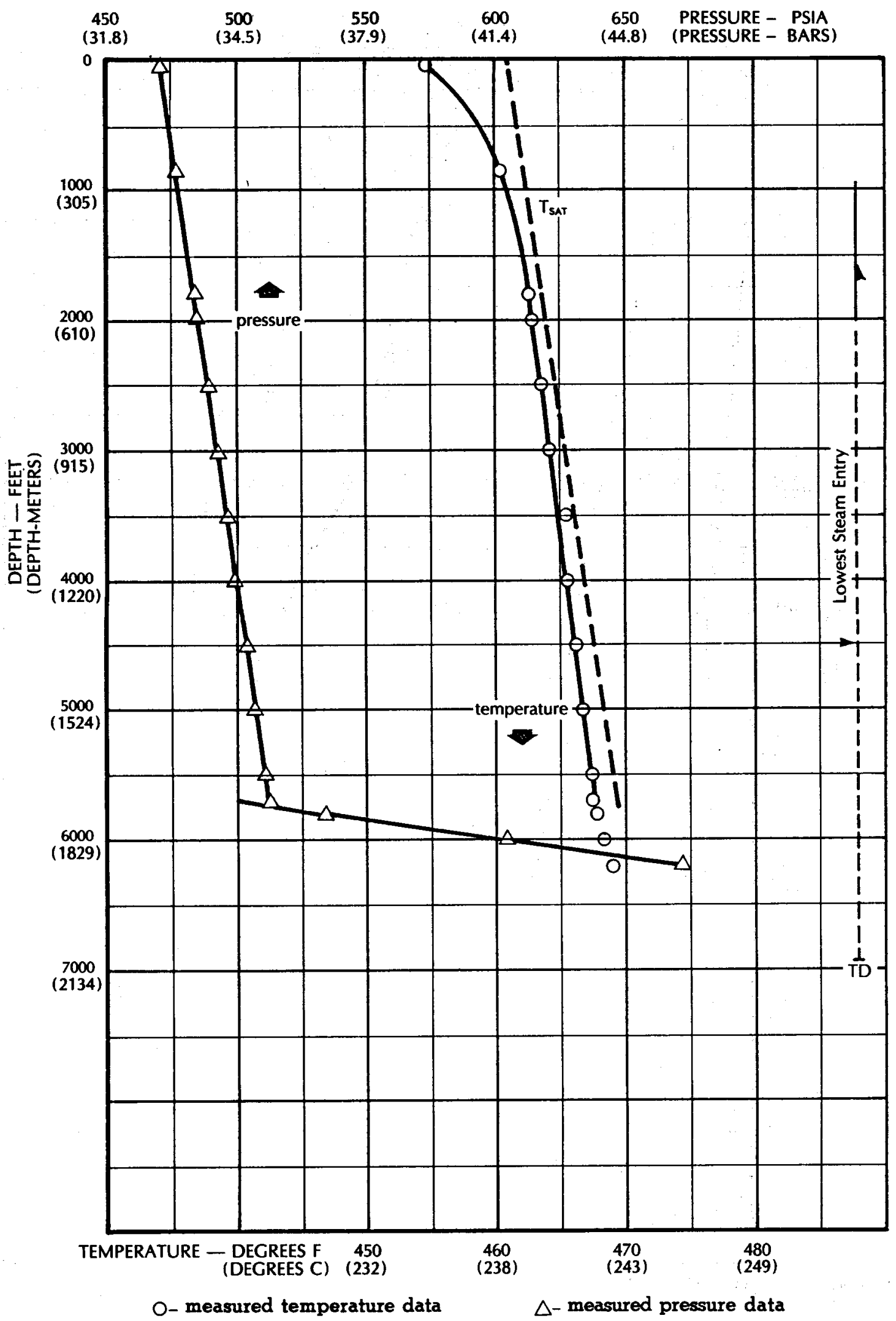

Figure 15. Static pressure and temperaturè surveys, Well B. 


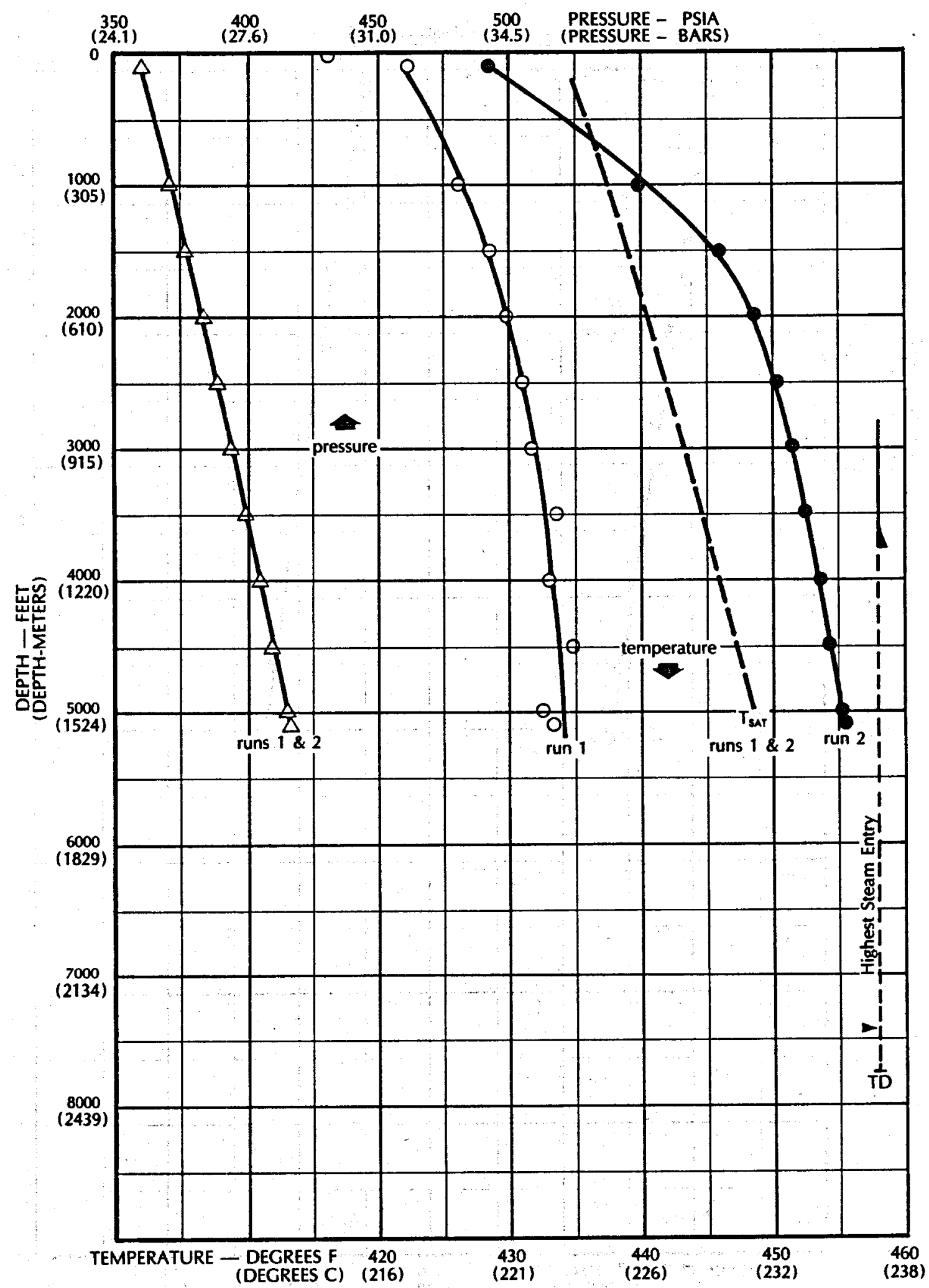

O-measured temperature data

$\Delta$-measured pressure data

Figure 16. Static pressure and temperature surveys, Well C. 


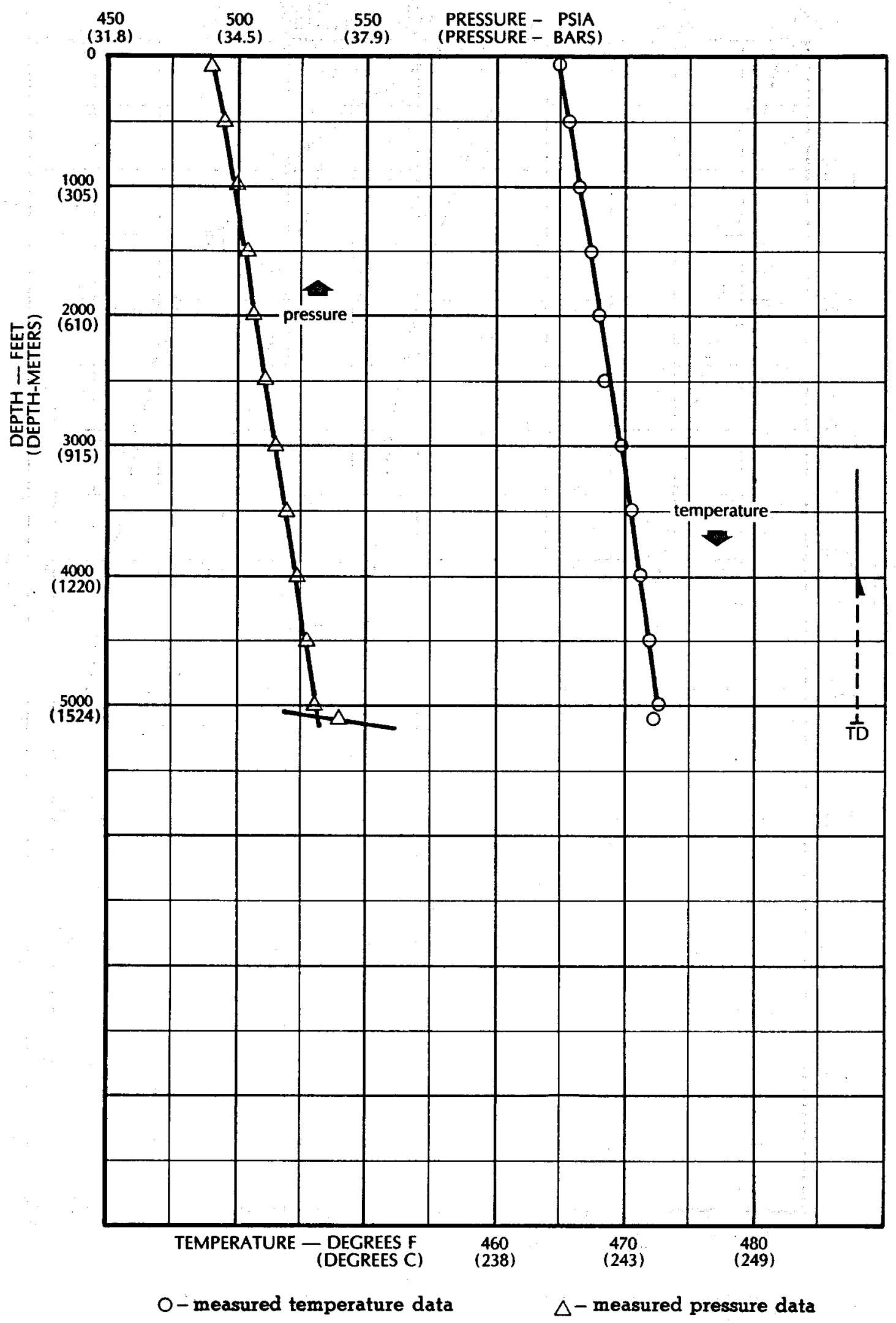

Figure 17. Static pressure and temperature surveys, Well D. 
Run 2 temperatures about $11^{\circ} \mathrm{C}\left(20^{\circ} \mathrm{F}\right)$ higher than Run 1 temperatures. The saturation temperature, based on the measured pressures for the two runs, falls about midway between the two measured temperature curves. The difference between the saturation temperature and the two measured curves, as with Well $A$, appears to be from instrument error. This is because it is highly unlikely to have divergent temperatures for separate runs with identical pressure profiles.

Figure 17 shows the measured pressure and temperature for Well D. For Well D, the saturation temperature, based on pressure, agrees almost exactly with the measured temperature.

A comment should be made regarding Well $C$. Well C pressure is lower than that of the other wells because, just below $1554 \mathrm{~m}(5,100$ feet), an obstruction (probably fill) was found in the well bore that prevented the instrument from going deeper. The fill could cause a significant drop in pressure within the well bore because the highest steam entry in the well is $518 \mathrm{~m}(1,700$ feet $)$ below the top of the obstruction. Thus, the pressure measured at $1,524 \mathrm{~m}(5,000$ feet $)$ does not represent the pressure in the steam reservoir.

Table 5 pressure data closely agree with the 35.4 bars absolute ( 514 psia) reported by Lipman and others as the average initial pressure in the steam reservoir at sea level datum.

\section{Pressure Buildup Behavior}

Several examples of pressure buildup curves of steam wells at The Geysers have been published. Ramey (1970) and Ramey and Gringarten (1976) presented a log-log buildup curve showing the characteristic storage of slope as 1 , the fracture behavior with slope as $31 / 2$, and the buildup behavior of a straight line on a Horner plot.

In another publication (1976), Ramey presented buildup curves for three steam wells at The Geysers, designated Wells $A, B$, and $C$, and indicated how the curves could be analyzed. One well showed the characteristic one-half slope of a fracture system. Another well was apparently damaged, based on the shape of the Horner buildup curve.

Strobel (1976) published type curves and buildup curves showing examples of storage effects and fracture behavior. He also gave an example of a problem curve showing the effect on the buildup curve of condensa-

Table 5. Wells (Run 1) B and D pressures and saturation temperatures at a depth of $1524 \mathrm{~m}$ (5,000 feet). Pressures are corrected to sea level datum and the corresponding saturation temperature. Well $A$ (Run 1 ) is not included because its pressure had not stabilized. Well $C$ is not included because of a well bore obstruction.

\begin{tabular}{|c|c|c|c|c|c|c|c|c|}
\hline \multirow[b]{2}{*}{ Well } & \multicolumn{2}{|c|}{$(1,524 \mathrm{~m})$} & \multicolumn{2}{|c|}{5,000 feet } & \multicolumn{2}{|c|}{ Sea level } & \multicolumn{2}{|c|}{ Sea level } \\
\hline & $\begin{array}{c}\text { Press. } \\
\text { bars }\end{array}$ & $\begin{array}{c}\text { Temp. } \\
{ }^{\circ} \mathrm{C}\end{array}$ & $\begin{array}{l}\text { Press. } \\
\text { psia }\end{array}$ & Temp. & $\begin{array}{c}\text { Press. } \\
\text { bars }\end{array}$ & Temp. & $\begin{array}{c}\text { Press. } \\
\text { psia }\end{array}$ & ${ }_{\bullet F}^{T e m p .}$ \\
\hline$A(\operatorname{Run} 2)$ & 36.3 & 244 & 526 & 472 & 35.6 & 243 & 517 & 470 \\
\hline B & 35.0 & 242 & 507 & 468 & 33.8 & 241 & 491 & 465 \\
\hline D & 36.7 & 245 & 532 & 473 & 35.8 & 244 & 519 & 471 \\
\hline
\end{tabular}

tion, or revaporization in the well bore. According to Strobel, this is the most prevalent problem in pressurebuildup testing of steam wells at The Geysers. An analysis cannot be made because the problem results in a buildup curve that does not have a straight line.

Economides and Fehlberg (1979) presented data on two buildup curves taken about a year apart for Shell Oil Company well "D-6". In the buildup tests, the data were analyzed for the kh (permeability-thickness) product of the well. The kh values were 6,400 and 8,800 millidarcy feet, with a more negative skin factor on the second test. The authors attribute the improvement to passage and fracture cleanup and channelization.

The well production rates were $59,874 \mathrm{~kg} / \mathrm{hr}$. $(132,000 \mathrm{lb} . / \mathrm{hr}$. $)$ and $75,296 \mathrm{~kg} / \mathrm{hr}$. $(166,000 \mathrm{lb}$./hr. $)$.For comparison, Ramey and Gringarten (1976) calculated a kh value of 22,700 millidarcy feet for a well with a flow rate of $51,710 \mathrm{~kg} / \mathrm{hr}$. $(114,000 \mathrm{lb}$. $/ \mathrm{hr}$. $)$.

\section{Reservoir Volume and Heat Content}

The approximate volume of The Geysers Geothermal field steam reservoir is a function of reservoir area and thickness. The area of the reservoir is probably known within a factor of 2 based on geology and dry hole locations around the periphery of the field. The top of the reservoir can be defined by the depth to the first steam entry. The bottom of the reservoir is unknown, but is assumed to be $-4,570 \mathrm{~m}(-15,000$ feet $)$ subsea depth (Table 6).

In the calculation, the $-1,500 \mathrm{~m}(-4,921$ feet) contour (Fig. 4) was assumed to be the field limit for commercial production (dashed contour lines indicate lack of data). The contours were extrapolated to the field's CDOG administrative boundaries, and both the contours and the boundaries were used to calculate the field area $6552 \mathrm{Ha}(16,190$ acres ). The bulk volume contained between the contours of the first steam entry from the surface to a depth of $-4,570 \mathrm{~m}(-15,000$ feet $)$ was calculated at $257.7 \mathrm{Gm}^{3}\left[9.1\right.$ (10) ${ }^{12}$ cubic feet].

Table 6. Calculation of heat in place above $93.3^{\circ} \mathrm{C}\left(200^{\circ} \mathrm{F}\right)$, The Geysers Geothermal field.

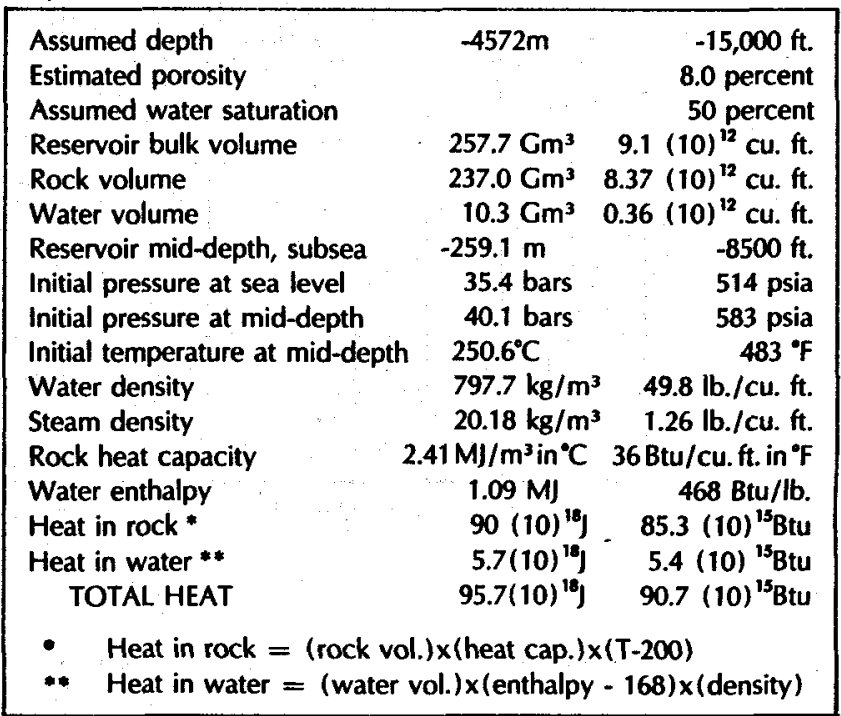


The amount of heat in place depends upon reservoir porosity, percentage of pore space occupied by water, thermal properties of the rock, and initial reservoir pressure. Porosity of The Geysers reservoir is estimated at 8 percent. The initial water saturation of the reservoir is assumed to be 50 percent.

The water saturation value at The Geysers has only a small effect on the total reservoir heat content, because most heat is in the reservoir rock. Reservoir rock heat capacity is $2.41 \mathrm{MJ} / \mathrm{m}^{3}$ in ${ }^{\circ} \mathrm{C}$ ( $36 \mathrm{Btu} / \mathrm{cu}$. $\mathrm{ft}$. in ${ }^{\circ} \mathrm{F}$ ).

The initial reservoir pressure is taken as 35.4 bars absolute (514 psia) at sea level datum. Because of the small change in pressure with depth, the calculation of heat content can be based on the midpoint pressure. Table 6 shows the calculation for the amount of heat in place. The total heat above $93^{\circ} \mathrm{C}\left(200^{\circ} \mathrm{F}\right)$ is $95.7(10)^{12}$ MJ $\left[90.7(10)^{15} \mathrm{Btu}\right]$ for the assumed depth of $4,570 \mathrm{~m}$ $(-15,000$ feet $)$.

\section{PRODUCTION AND INJECTION CHARACTERISTICS}

\section{Individual Well Production Behavior}

The initial steam production rate from a new well depends on penetrated fracture sizes and number, hole and casing sizes, depth, reservoir pressure, and the reservoir, itself. For high steam rates, production is limited primarily by hole size. For low rates, production is lim- ited by the effective kh (permeability-thickness product) of the reservoir around the well bore. Actual initial well production rates in The Geysers Geothermal field range from subcommercial rates of $9,070 \mathrm{~kg} / \mathrm{hr}$. $(20,000$ lb./hr. $)$ to rates as high as $177,810 \mathrm{~kg} / \mathrm{hr}$. $(392,000 \mathrm{lb} . /$ hr.) (Magma Power Co., 1980). Fourteen wells have reported maximum production rates over 113,400 $\mathrm{kg} / \mathrm{hr}$. $(250,000 \mathrm{lb} . / \mathrm{hr}$.) and 4 wells over $136,080 \mathrm{~kg} / \mathrm{hr}$. $(300,000 \mathrm{lb} . / \mathrm{hr}$.$) . Effects of depth and hole size were$ illustrated by Budd (1972), who presented two graphs showing how rate versus wellhead pressure calculations were affected by hole size and depth.

Production decline curves over a 6- to 12-year period for 11 wells at The Geysers are in Figures 18-24. The initial rates varied within an approximate five-fold range. The initial well spacing varied from about $2.0 \mathrm{Ha}(5$ acres) per well in the Happy Jack, Sulphur Bank, and Thermal areas in the old part of the field, to about $\mathbf{1 6 . 2}$ $\mathrm{Ha}$ (40 acres) per well for the other developed portions of the field. All of the production data were not available for wells "Sulphur Bank" 7 and "Thermal" 10 because, prior to April 1968, only kilowatt-hours of electricity generated were reported. Well "Thermal" 10 actually went on production into power plant Unit 1 in September 1960 and "Sulphur Bank" 7 into Unit 3 in July 1967.

These production curves can be compared with Budd's (1972) calculated curves for well spacings of 18.2 $\mathrm{Ha}, 8.1 \mathrm{Ha}$, and $2.0 \mathrm{Ha}$ ( 45 acres, 20 acres, and 5 acres) per well. The average behavior for these wells falls about midway between the $8.1 \mathrm{Ha}$ and $2.0 \mathrm{Ha}(20$

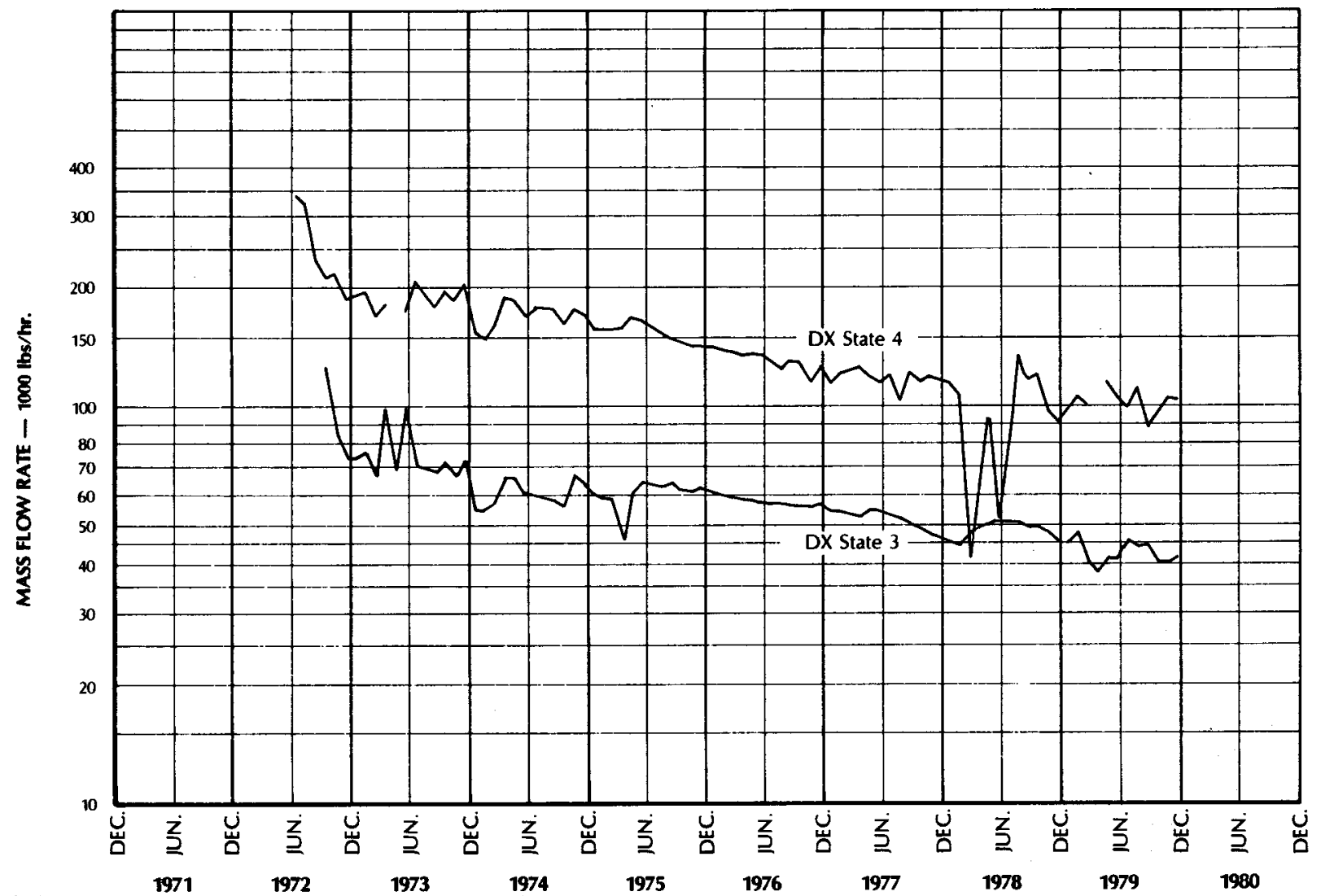

Figure 18. Steam production rate vs. time, wells "DX State" 3 and 4, The Geysers Geothermal field. 


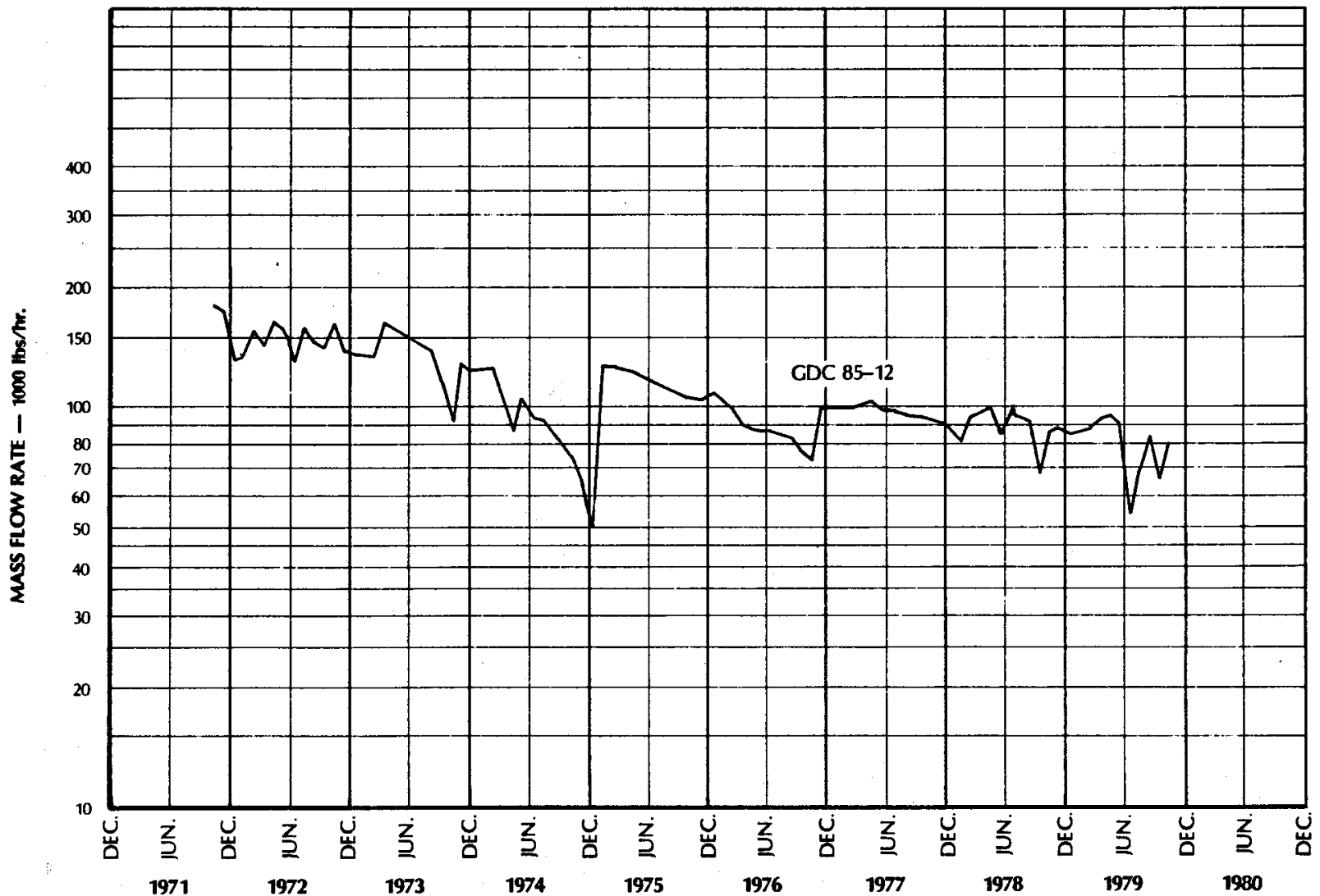

Figure 19. Steam production rate vs. time, well "GDC" 85-12 The Geysers Geothermal field.

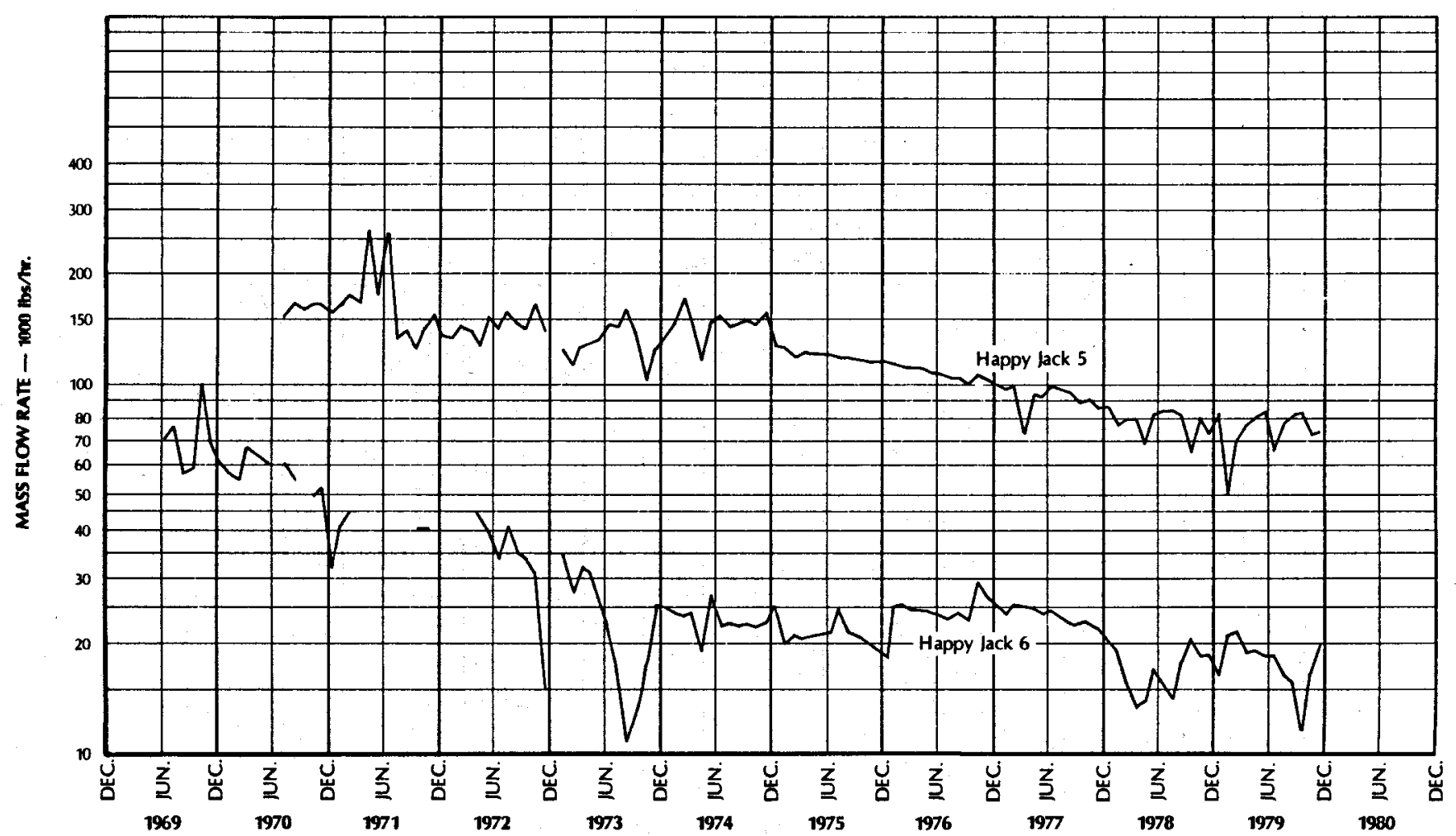

Figure 20. Steam production rate vs. time, wells "Happy Jack" 5 and 6, The Geysers Geothermal field. 


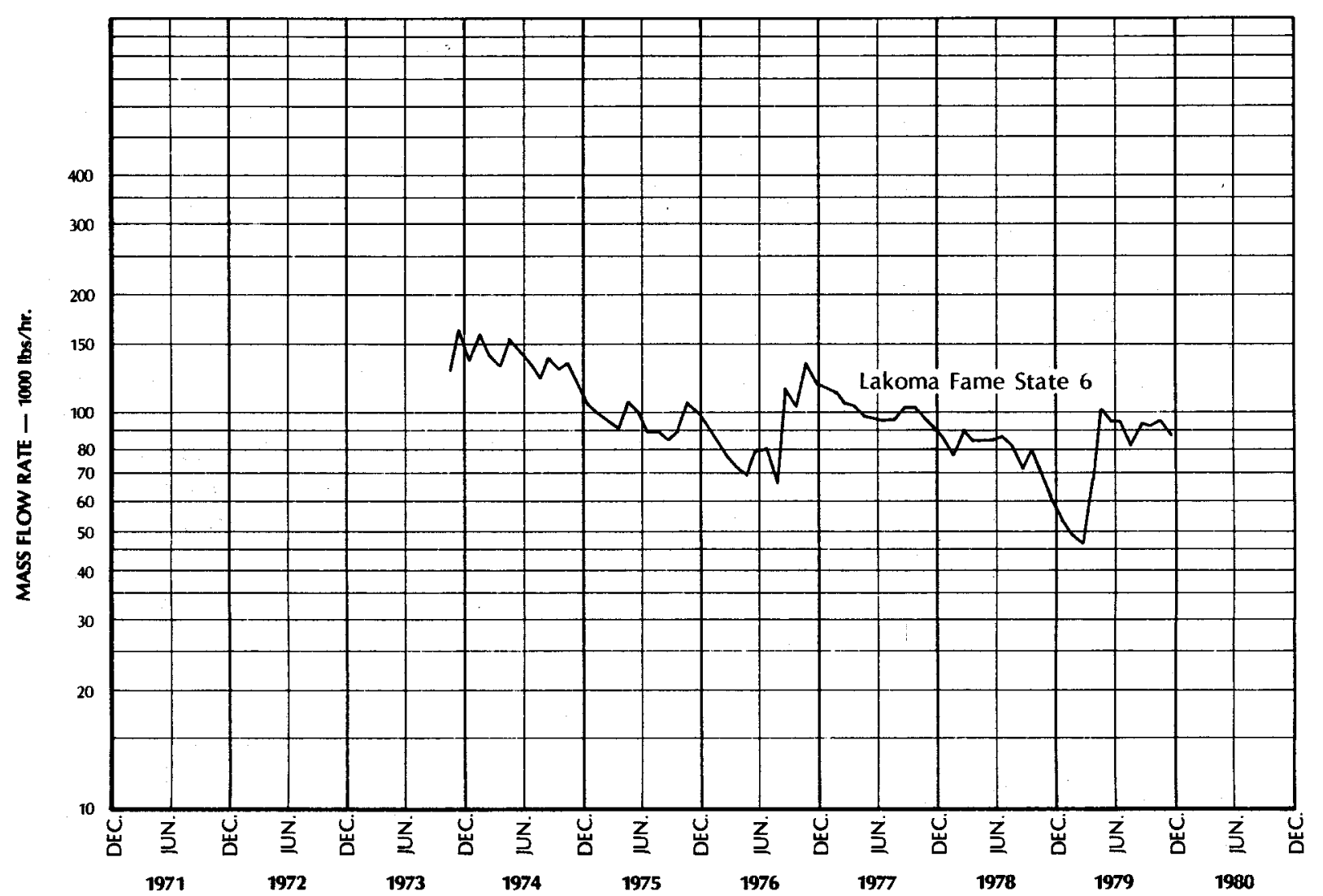

Figure 21. Steam production rate vs. time, well "Lakoma Fame State" 6, The Geysers Geothermal field.

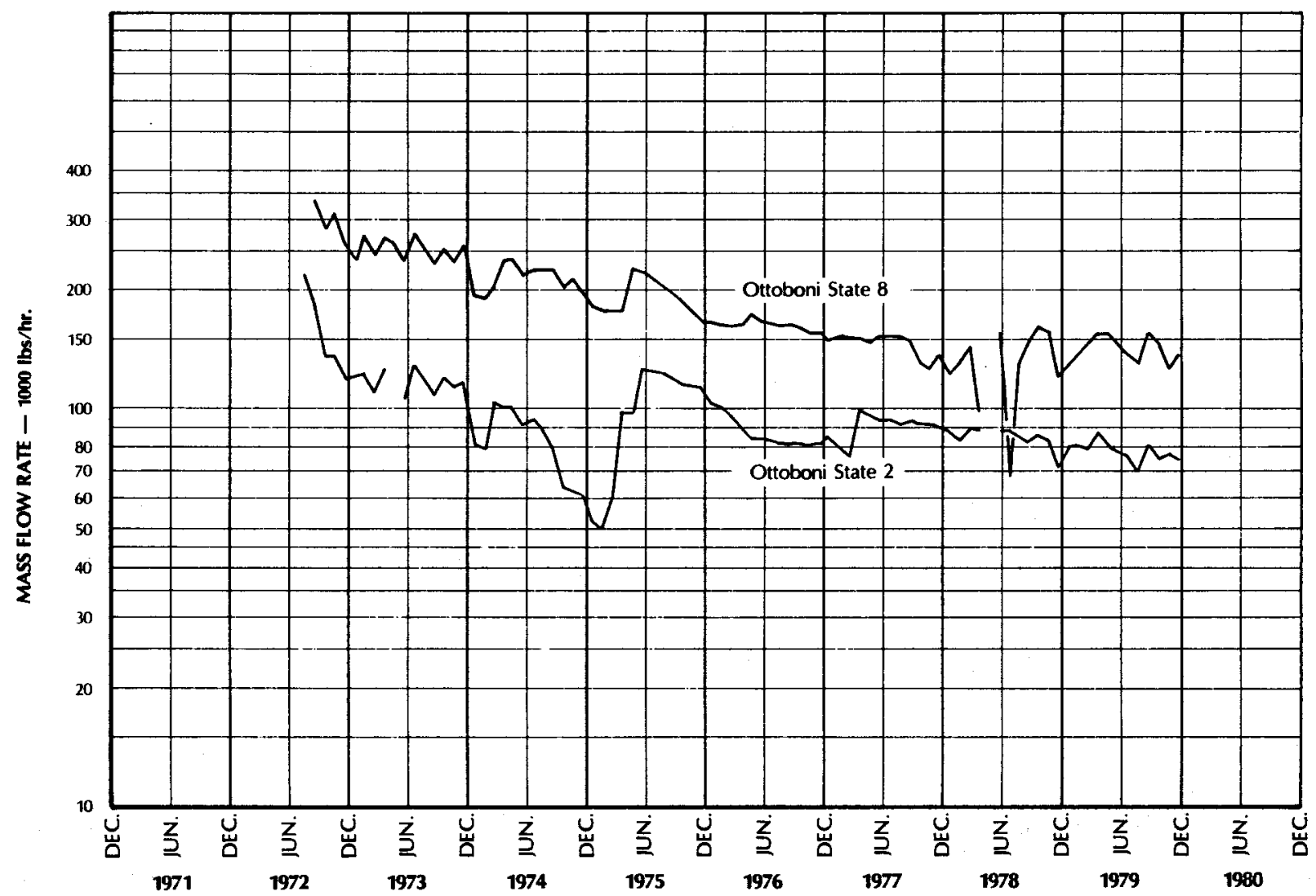

Figure 22. Steam production rate vs. time, wells "Ottoboni State" 2 and 8, The Geysers Geothermal field. 


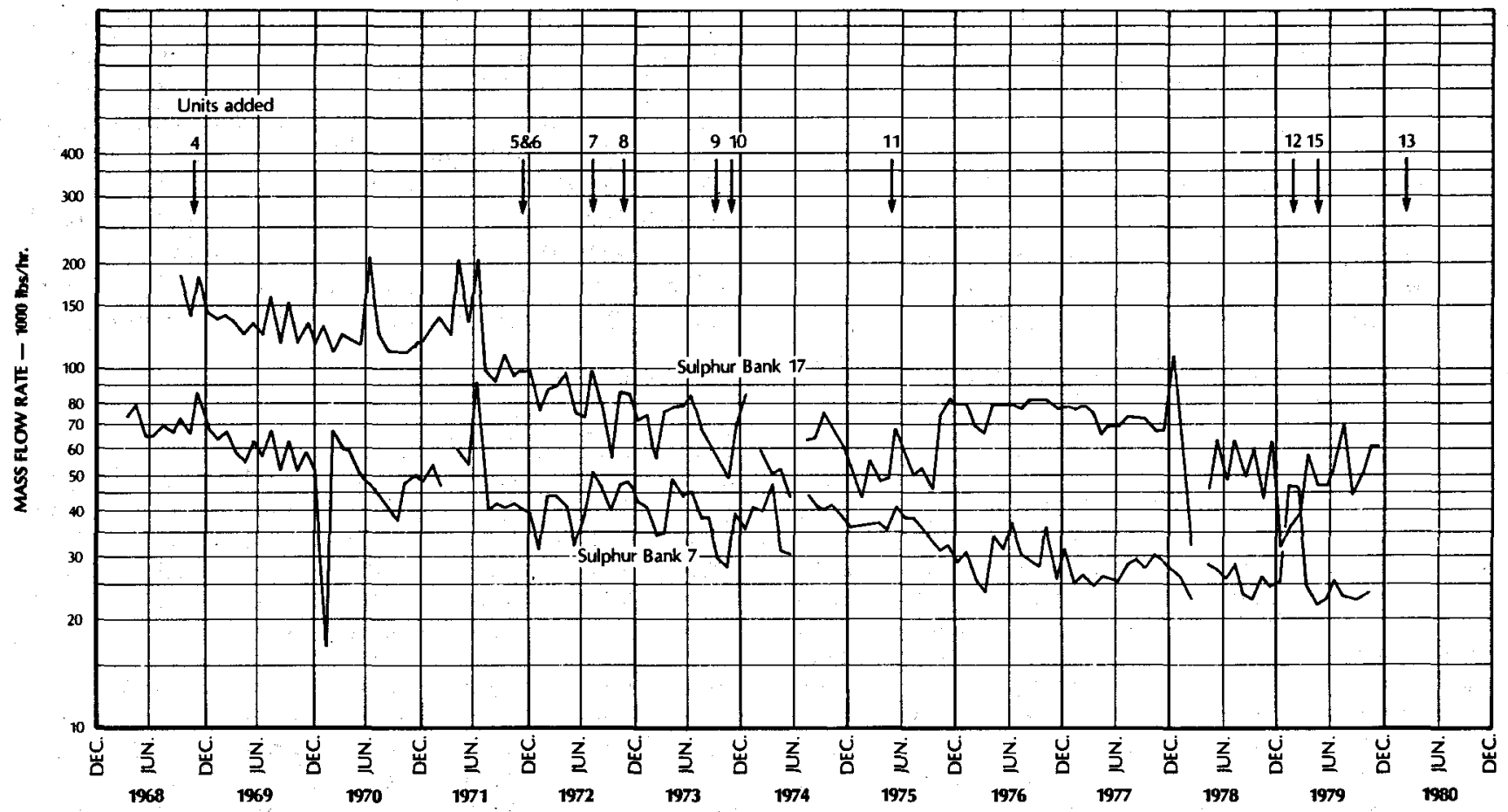

Figure 23. Steam production rate vs. time, wells "Sulphur Bank" 7 and 17, The Geysers Geothermal field.

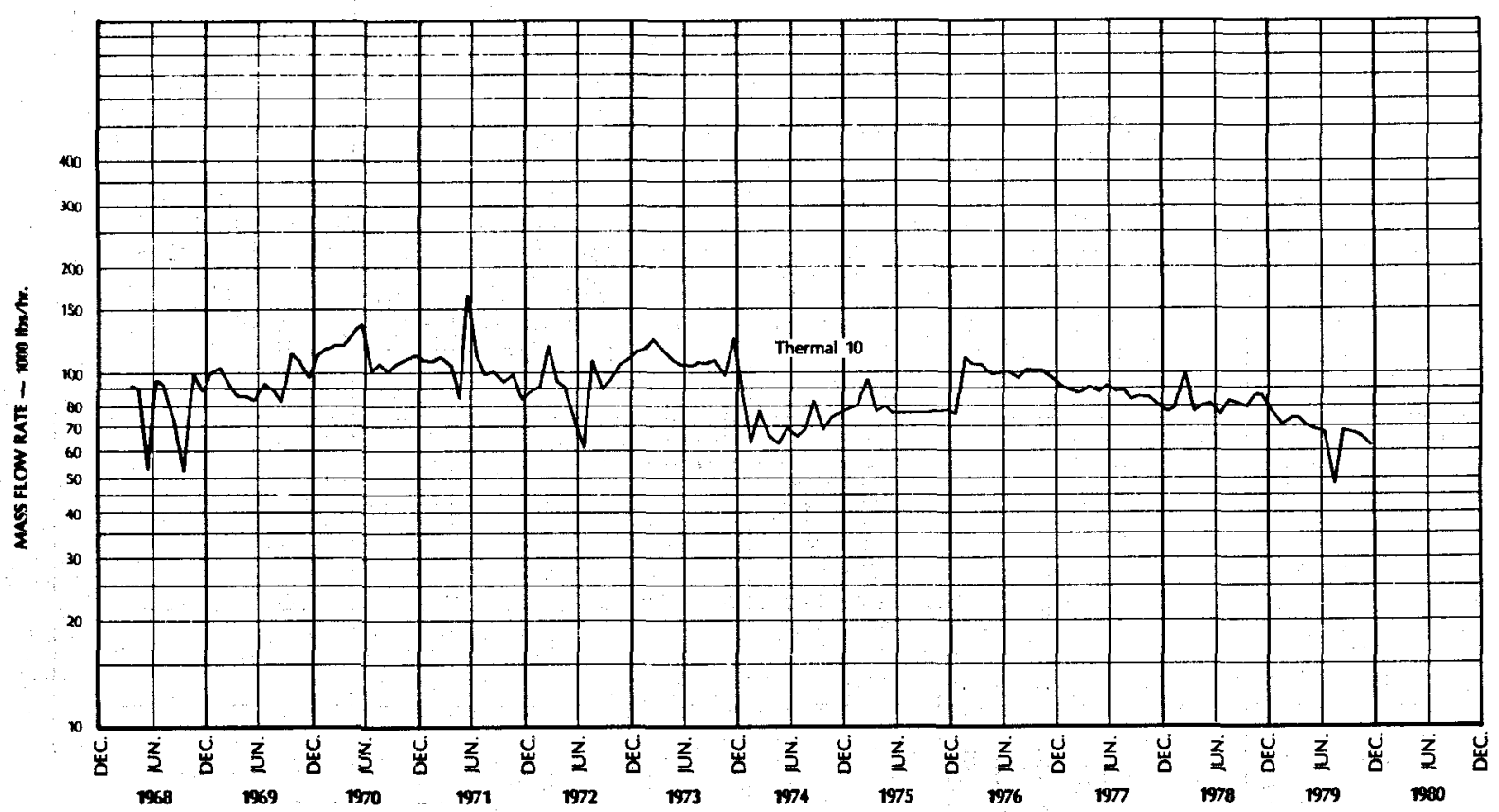

Figure 24. Steam production rate vs. time, well "Thermal" 10, The Geysers Geothermal field. 
acre and 5 acre) curves of Budd. The average decline at the end of eight years is 50 percent. Budd's projected curves show a decline at the end of eight years of 33 percent for $8.1 \mathrm{Ha} \mathrm{(20} \mathrm{acre)} \mathrm{spacing} \mathrm{and} 60$ percent for $2.0 \mathrm{Ha}$ (5 acre) spacing.

\section{Field Production History}

Field production history at The Geysers is directly related to field power plant development. As each power plant started operating, field production rates were increased to meet the new demands.

Monthly production data are in Table 7 and Figure 25. As of December 1980, when 930 Megawatts of electricity $(\mathrm{MWe})$ were installed, the maximum rate of steam production occurred in November 1980, when 4.995 Mkg (11,013 million pounds) of steam were produced.

Yearly production data and cumulative data are in Table 8. The total production in the table includes field production from wells on stream and estimated production consisting of: (1) flow from blowout well "Thermal" 4; (2) flow from wells that are being vented; and

Table 7. Steam production, in billion pounds per month, The Geysers Geothermal field.

\begin{tabular}{|c|c|c|c|c|c|c|c|c|c|c|c|c|c|}
\hline Month & 1968 & 1969 & 1970 & 1971 & 1972 & 1973 & 1974 & 1975 & 1976 & 1977 & 1978 & 1979 & 1980 \\
\hline Jan. & & 1.194 & 1.295 & 1.544 & 1.955 & 3.375 & 4.967 & 4.429 & 6.199 & 6.097 & 6.282 & 5.823 & 6.712 \\
\hline Feb. & & 0.916 & 1.267 & 1.211 & 2.086 & 3.204 & 4.406 & 4.118 & 5.752 & 5.465 & 5.443 & 4.909 & 6.749 \\
\hline Mar. & & 1.228 & 0.881 & 1.078 & 2.523 & 3.300 & 5.094 & 4.803 & 6.252 & 5.990 & 4.838 & 6.586 & 7.472 \\
\hline Apr. & 0.736 & 1.183 & 1.355 & .944 & 2.597 & 3.890 & 4.798 & 4.795 & 5.568 & 5.485 & 3.868 & 6.188 & 7.628 \\
\hline May & 0.909 & 1.260 & 1.372 & 1.102 & 2.611 & 3.649 & 4.609 & 5.448 & 5.526 & 5.812 & 3.736 & 6.311 & 8.860 \\
\hline June & 0.723 & 1.213 & 1.059 & .834 & 2.348 & 4.104 & 4.470 & 6.162 & 5.726 & 5.964 & 4.495 & 6.405 & 8.550 \\
\hline July & 0.497 & 1.257 & 1.089 & 1.459 & 2.512 & 4.510 & 4.797 & 6.390 & 6.272 & 6.299 & 5.006 & 6.875 & 9.225 \\
\hline Aug. & 0.772 & 1.335 & 1.196 & 1.558 & 3.452 & 4.088 & 4.905 & 6.463 & 6.254 & 5.699 & 5.694 & 7.458 & 9.715 \\
\hline Sep. & 0.731 & 1.376 & 1.099 & 1.532 & 3.199 & 3.766 & 4.718 & 5.951 & 6.103 & 6.099 & 5.929 & 6.808 & 9.009 \\
\hline Oct. & 1.155 & 1.405 & 1.135 & 1.330 & 3.432 & 4.030 & 4.502 & 6.349 & 5.793 & 6.324 & 4.569 & 6.742 & 10.108 \\
\hline Nov. & 1.067 & 1.274 & 1.093 & 2.109 & 4.143 & 4.075 & 5.311 & 6.072 & 5.203 & 6.190 & 5.021 & 6.914 & 11.013 \\
\hline Dec. & 1.160 & 1.399 & 1.461 & 2.525 & 3.925 & 5.529 & 5.469 & 6.249 & 5.850 & 6.285 & 6.079 & 8.121 & 10.928 \\
\hline Total & 7.750 & 15.040 & 14.302 & 17.226 & 34.783 & 47.320 & 58.046 & 67.229 & 70.498 & 71.709 & 60.960 & 79.140 & 105.964 \\
\hline
\end{tabular}

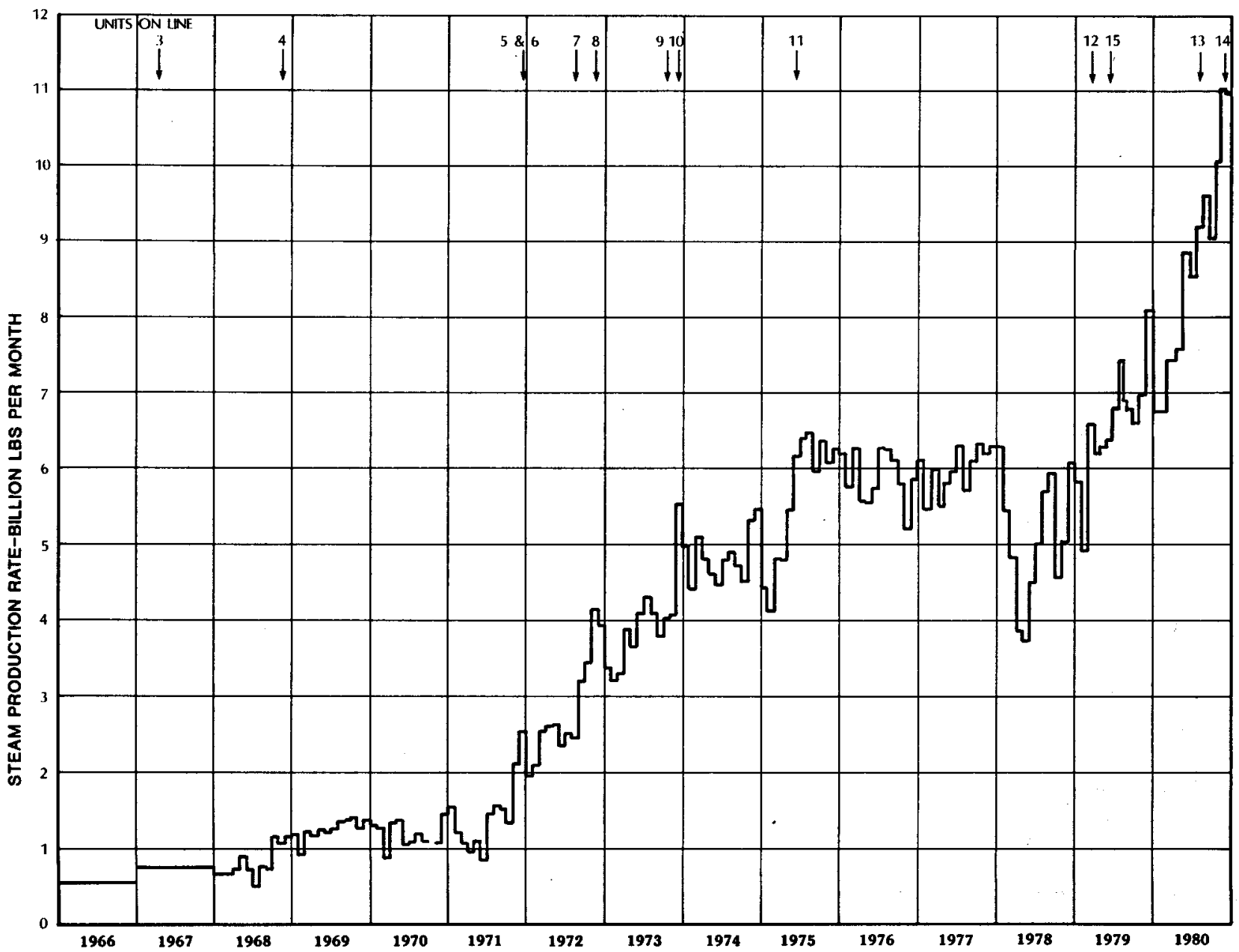

Figure 25. Monthly production rate of The Geysers Geothermal field. 
Table 8. Yearly production, in million pounds, The Geysers Geothermal field.

\begin{tabular}{|ccccc|}
\hline & $\begin{array}{c}\text { Field } \\
\text { Year }\end{array}$ & $\begin{array}{c}\text { Production (a) } \\
\text { Estimated } \\
\text { Other (a) }\end{array}$ & $\begin{array}{c}\text { Total Steam } \\
\text { Production(a) }\end{array}$ & $\begin{array}{c}\text { Cum. } \\
\text { Production in } \\
\text { billion pounds }\end{array}$ \\
\hline 1957 & 110 & 997 & 1107 & 1.11 \\
1958 & 113 & 2470 & 2583 & 3.69 \\
1959 & 442 & 2429 & 2871 & 6.56 \\
1960 & 1013 & 2192 & 3205 & 9.77 \\
1961 & 2273 & 2219 & 4492 & 14.26 \\
1962 & 2422 & 2024 & 4446 & 18.70 \\
1963 & 4025 & 2098 & 6123 & 24.83 \\
1964 & 5892 & 2058 & 7950 & 32.78 \\
1965 & 5763 & 1988 & 7751 & 40.53 \\
1966 & 6639 & 1864 & 8503 & 49.03 \\
1967 & 9079 & 1722 & 10801 & 59.83 \\
1968 & 9822 & 1791 & 11613 & 71.44 \\
1969 & 15019 & 1743 & 16762 & 88.21 \\
1970 & 14365 & 1892 & 16217 & 104.44 \\
1971 & 17321 & 1720 & 19041 & 123.46 \\
1972 & 34783 & 2039 & 36822 & 160.29 \\
1973 & 47320 & 2231 & 49551 & 209.84 \\
1974 & 58045 & 2418 & 60463 & 270.30 \\
1975 & 67387 & 2440 & 69827 & 340.13 \\
1976 & 71015 & 2191 & 73206 & 413.33 \\
1977 & 71567 & 1714 & 73281 & 484.57 \\
1978 & 60960 (b) & - & - & 545.53 (c) \\
1979 & 79140 (b) & - & - & 624.67 (c) \\
1980 & 105964 (b) & - & - & 730.63 (c) \\
& & & & \\
(a) Reference (Pacific Gas and Electric, 1979 ). & \\
(b) From Table 7. & & & \\
(c) Does not include "estimated other." & \\
\hline
\end{tabular}

(3) flow from tests on wells that are being drilled (Pacific Gas and Electric Company). By the end of December 1980, cumulative field steam production was $331.4 \mathrm{Gkg}$ ( 730.6 billion pounds).

\section{Water Injection}

Water injection into The Geysers reservoir began in May 1969, after the conversion of "Sulphur Bank" 1 into an injection well. The injected water was power plant condensate. In 1979, Union Oil Company supplemented the condensate water with water from Big Sulphur Creek.
Chasteen (1976) discussed condensate injection into The Geysers reservoir. He said that the first five injection wells were drilled originally as production wells. Their conversion to injection status required the placement of slotted liners across the injection zones to prevent hole sloughing. Since then, some injection wells have been drilled specifically for injection near the center of pressure sinks. These are usually drilled deeper to place the injection interval below the producing interval, helping to avoid liquid water breakthrough into a producing steam well.

The monthly water injection rates are in Table 9, along with the yearly total and the cumulative total through December 1980 . The cumulative amount of water injected is 64.0 billion $\mathrm{kg}$ or 403.0 million barrels (141.1 billion pounds). This is 19 percent of the 331.4 billion $\mathrm{kg}$ ( 730.6 billion pounds) of steam produced. During 1980, 11.1 billion $\mathrm{kg}$ ( 24.5 billion pounds) of water or 69.9 million barrels were injected. This is 23 percent of the reported production of 48.1 billion $\mathbf{~ k g}$ ( 106 billion pounds) for the same period of time.

\section{RESERVOIR ANALYSIS}

Four methods of analyzing the reservoir at The Geysers geothermal reservoir are material-energy balance, decline curve analysis, volumetric analysis, and heat recovery.

\section{Material - Energy Balance}

A material-energy balance applied to a geothermal reservoir has been described by Whiting and Ramey (1969). To use their equations, the average reservoir pressure as a function of time is required along with production data and enthalpy of produced fluids. Such data are not available for The Geysers because the field has not been developed as a unit. Pressure sinks have formed around the producing areas, while other areas of the field remain at near-original pressures, making an average field pressure meaningless. Pressure data for a small portion of the field in the Sulphur Bank, Happy Jack, and Big Geysers area are not available, except for the data published by Lipman and others (1977). There-

Table 9. Monthly water injection, in million barrels per month, The Geysers Geothermal field.

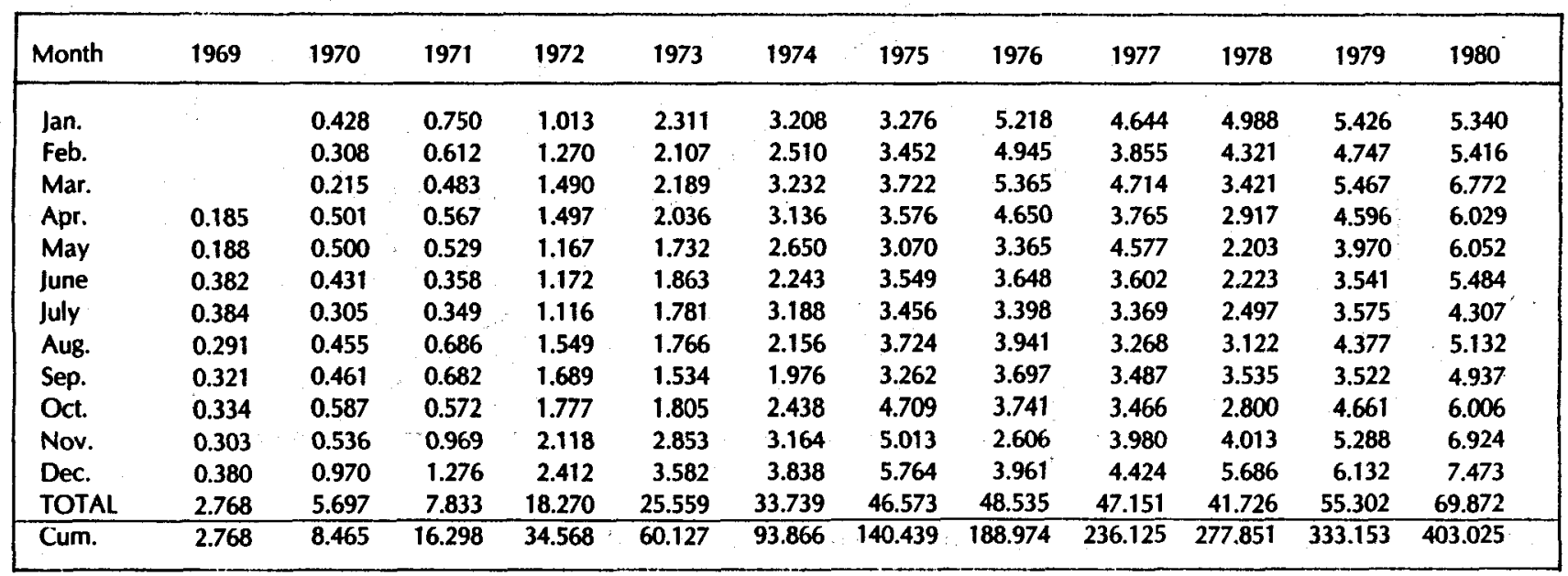


fore, until the necessary data become available, a material balance cannot be made.

Water influx, or recharge as it is sometimes called, is an important factor that may affect the performance of a geothermal reservoir. This factor could be particularly important in a steam reservoir because the low density of steam in relation to the density of liquid water can result in a small mass of steam in the reservoir for low water saturations.

The question of recharge was discussed by Ramey (1970), who concluded that the steam reservoir could not be subject to significant recharge. His observation is confirmed by the pressure data presented by Lipman and others (1977), and by the pressure data in Figures 14 to 17.

However, there may be recharge. Water may enter from a low pressure source as reservoir pressure declines, but such a source can exist only with a free surface level far below the ground surface. Such a free surface is not known to exist in The Geysers Geothermal field.

\section{Decline Curve Analysis}

An average production decline curve was calculated from 18 wells typifying the production behavior of the several field areas with 7 or more years of production history. The average curve, depicted as the upper curve in Figure 26, showed a decline of 50 percent in 8 years. The average decline was compared with the dimensionless decline-type curves presented by Fetkovich (1973). The closest match obtained was with the harmonic-type curve for $b=1.0$ shown in Figure 10 of the Fetkovich paper. Extrapolations of the average curve along the matched harmonic curve indicated a decline of $\mathbf{7 1 . 5}$ percent at the end of 20 years and of 79 percent at the end of 30 years (see lower curve in Fig. 26).

For The Geysers Geothermal field, the decline curve is used mainly to determine the number of infill wells required to maintain a constant rate of steam production into the power plants. For example, if a geothermal field is initially developed on $16.2 \mathrm{Ha} \mathrm{(40} \mathrm{acre)} \mathrm{spacing,} \mathrm{then}$

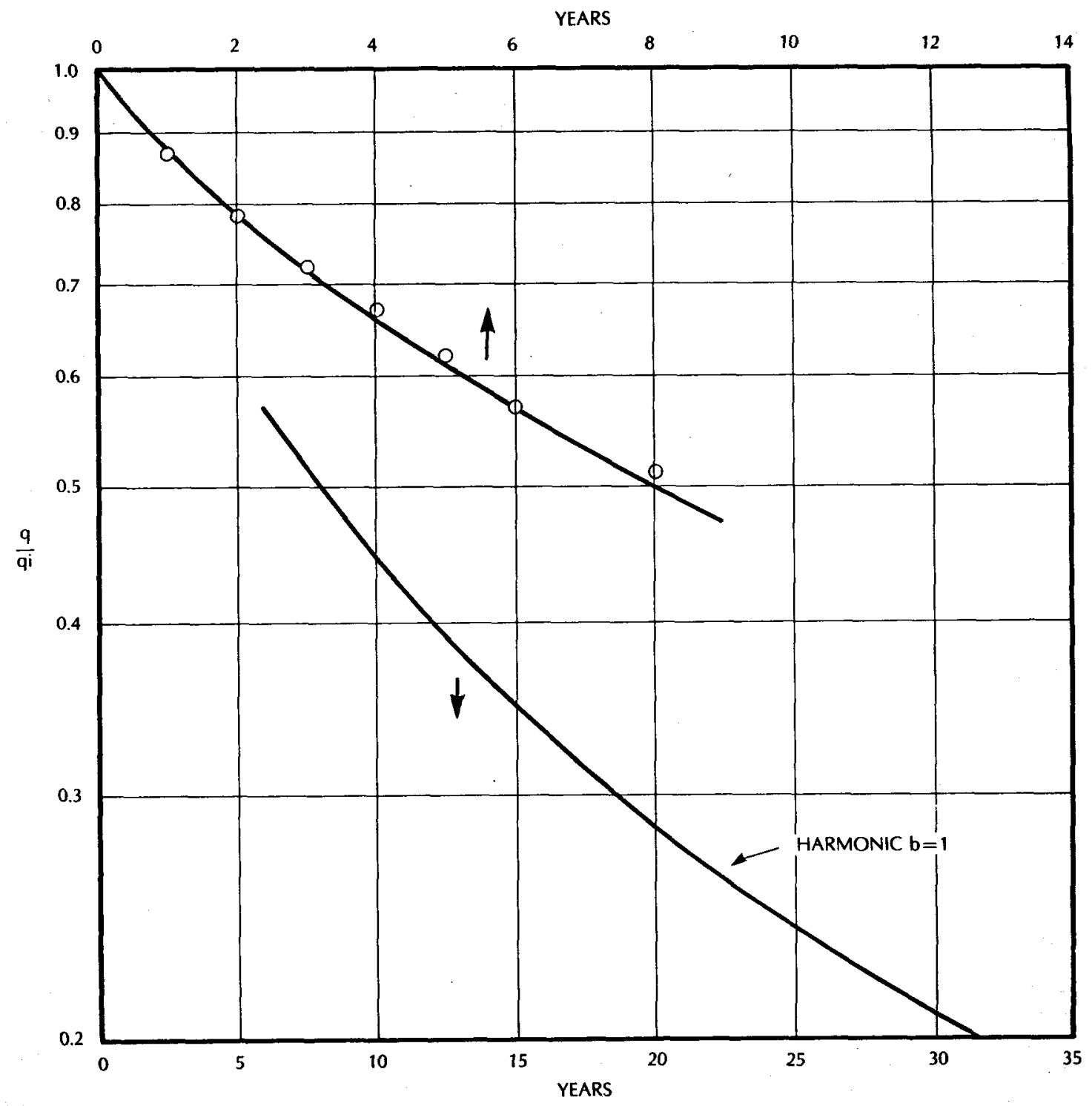

Figure 26. Average decline curve for a steam well at The Geysers Geothermal field. 
a decline to 20 percent of the initial rate will require from

- 4 to 5 times as many wells. The actual number of wells will depend on the amount of excess production capacity available at the plant start up, and on the producing rate of the infill wells. Additional drilling may result in well spacings as low as $3.2 \mathrm{Ha}$ ( 8 acres) to $4.0 \mathrm{Ha}(10$ acres) per well. However, the economics of well drilling will determine whether or not wells can be drilled so closely.

Infill wells may have an interference effect on the surrounding producing wells. Thus, the extrapolation of a production decline curve based on past performance can be subject to considerable error or doubt if infill drilling occurs.

\section{Volumetric Analysis}

An estimate of the bulk volume of the reservoir, in the "Reservoir Volume and Heat Content" section of this chapter, is for an assumed depth of $4,570 \mathrm{~m}(-15,000$ feet) subsea depth. The pore volume was calculated as $20.67 \mathrm{Gm}^{3}\left(.73(10)^{12} \mathrm{cu}\right.$. ft.) (see Table 6). If 50 percent of the volume initially contained water of average density of $797.7 \mathrm{~kg} / \mathrm{m}^{3}(49.8 \mathrm{lb} . / \mathrm{cu}$. ft. $)$, the amount of water in place would be $8255.4 \mathrm{Gkg}\left(18.1(10)^{12} \mathrm{lb}.\right)$. The amount of steam in place with a steam density of $20.18 \mathrm{~kg} / \mathrm{m}^{3}$ ( $1.26 \mathrm{lb} . / \mathrm{cu}$. ft.) would be $208.6 \mathrm{Gkg}(.46$ (10) ${ }^{12} \mathrm{lb}$.). The total of the two fluids is $8436.8 \mathrm{Gkg}$ $\left(18.6(10)^{12} \mathrm{lb}\right.$.). The cumulative production (Table 8) less cumulative injection through Dec.1980 is $331.6 \mathrm{Gkg}$ $-64.0 \mathrm{Gkg}=267.6 \mathrm{Gkg}\left[731(10)^{9}-350 \times 403(10)^{6}\right.$ $=590(10)^{9} \mathrm{lb}$.]. This is 3.2 percent by weight of the amount of water and steam estimated to be initially in place.

These calculations illustrate the importance of injecting water in a geothermal reservoir to sustain the life of the field. Without this practice, the field life could be limited to the amount of fluid initially in the reservoir. Such limitations are unnecessary because the reserve of a geothermal reservoir is the heat contained in it rather than the fluid content, and a fluid can be injected to recover the heat as long as it is available and economical to do so.

\section{Heat Recovery}

Heat recovery depends upon the enthalpy of produced fluid. McNitt (1963) reported enthalpies between $2789 \mathrm{~kJ} / \mathrm{kg}(1199 \mathrm{Btu} / \mathrm{lb}$.) and $2808 \mathrm{~kJ} / \mathrm{kg}$ (1207 Btu/lb.) for three wells. Ramey (1970) plotted pressure versus temperature for the tests in Big Geysers area wells. He also included the saturation line and lines of constant enthalpy of $2791 \mathrm{~kJ} / \mathrm{kg}(1200 \mathrm{Btu} / \mathrm{lb}$.) and $2814 \mathrm{~kJ} / \mathrm{kg}$ (1210 Btu/lb.). Except for one well, all the points fell between the saturation line and the $2814 \mathrm{~kJ} / \mathrm{kg}$ (1210 Btu/lb.) enthalpy line. The maximum enthalpy of steam in equilibrium with water is $2801.9 \mathrm{~kJ} / \mathrm{kg}$ ( 1204.6 $\mathrm{Btu} / \mathrm{lb}$.), and this value seems to closely represent the enthalpy of steam in place.

Assuming that the enthalpy of the produced steam is. $2803 \mathrm{~kJ} / \mathrm{kg}$ (1205 Btu/lb.), the amount of heat above $93.3^{\circ} \mathrm{C}\left(200^{\circ} \mathrm{F}\right)$ produced through June 1980 is:

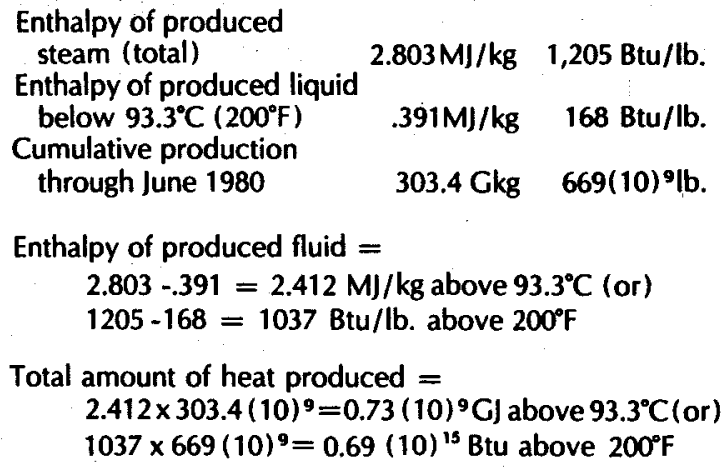

This is 0.8 percent of the estimated amount of heat initially in place $95.7(10)^{10} \mathrm{~J}$ (or) $\left(90.7(10)^{15} \mathrm{Btu}\right)$ from Table 6 .

An approximate amount of heat remaining in the reservoir can be calculated for an assumed heat recovery of 20 percent.

$$
\begin{aligned}
& \text { Heat recovery factor } \\
& \text { Initial heat in place } 95.7(10)^{9} \mathrm{G} \text { ) (or) } 90.7(10)^{15} \mathrm{Btu} \\
& \begin{array}{c}
\text { Amount of heat produced } \\
\text { (through June 1980) } .73(10)^{9} \mathrm{G} \text { ) (or) } .69(10)^{15} \mathrm{Btu}
\end{array} \\
& \text { Initial recoverable heat }= \\
& .20 \times 95.7(10)^{9}=19.14(10)^{9} \mathrm{G} \text { ) (or) } \\
& .20 \times 90.7(10)^{15}=18.14(10)^{15} \mathrm{Btu} \\
& \text { Remaining recoverable heat as of July } 1980= \\
& \left.19.14(10)^{9} \mathrm{G}\right)-.73(10)^{9} \mathrm{G}=18.41(10)^{9} \mathrm{G} \text { (or) } \\
& 18.14 \times 10^{15}-.69(10)^{15}=17.45(10)^{15} \mathrm{Btu}
\end{aligned}
$$

The amount of steam needed to produce an average MWe can be calculated from steam production in years that no power plants were added. Using steam production for the years 1970, 1974, and 1976-78 yields a value of $63,500 \mathrm{~kg} / \mathrm{yr} . / \mathrm{G}]\left[0.14(10)^{9} \mathrm{lb} . / \mathrm{yr} . / \mathrm{MWe}\right]$. Into this value is calculated the effect of power plants operating below 100 percent capacity. From this value, the estimated life of the field is calculated.

$$
\begin{aligned}
& \text { Amount of steam needed } \\
& \text { to produce } 1 \mathrm{MWe} \quad 6,350 \mathrm{~kg} / \mathrm{yr} . / \mathrm{G} \text { ) (or) } \\
& 0.14(10)^{9} \mathrm{lb} . / \mathrm{yr} . / \mathrm{MWe} \\
& \text { Enthalpy of produced fluid } \\
& \text { above } \left.93.3^{\circ} \mathrm{C}\left(200^{\circ} \mathrm{F}\right) \quad 2.412 \mathrm{M}\right) / \mathrm{kg} \text { (or) } \\
& \text { 1,037 Btu/lb. } \\
& 17.45(10)^{15} \text { Btu } \\
& \frac{17.45(10)^{13}}{0.145(10)^{12}}=120,000 \mathrm{MWe} / \mathrm{yr} \text {. (or) } \\
& \frac{18.41(10)^{15}}{0.153(10)^{12}}=120,000 \mathrm{MWe} / \mathrm{yr}
\end{aligned}
$$

At the current generating capacity of $930 \mathrm{MWe}$, the estimated life of The Geysers Geothermal field reservoir is 129 years. At the anticipated maximum generating capacity of 2,000 MWe (as of 1990), the estimated life of the field is 60 years. 



\section{DRILLING TECHNOLOGY}

\section{DRILLING}

Procedures for drilling and completing steam wells at The Geysers Geothermal field have remained unchanged for several years, and a considerable amount of information has been published on the topic. The drilling and completion practices included in the following discussion represent an application of the best available technology.

Before drilling begins at The Geysers or other California geothermal fields, the operator must notify and receive all necessary permits from appropriate county, state, and/or federal agencies.

Each well is drilled according to a detailed drilling plan, using a conventional oilfield rotary rig capable of drilling up to $3,700 \mathrm{~m}$ (12,000 feet). A typical casing, cementing, and drilling program used at The Geysers Geothermal field is described in Figure 27. Although these practices

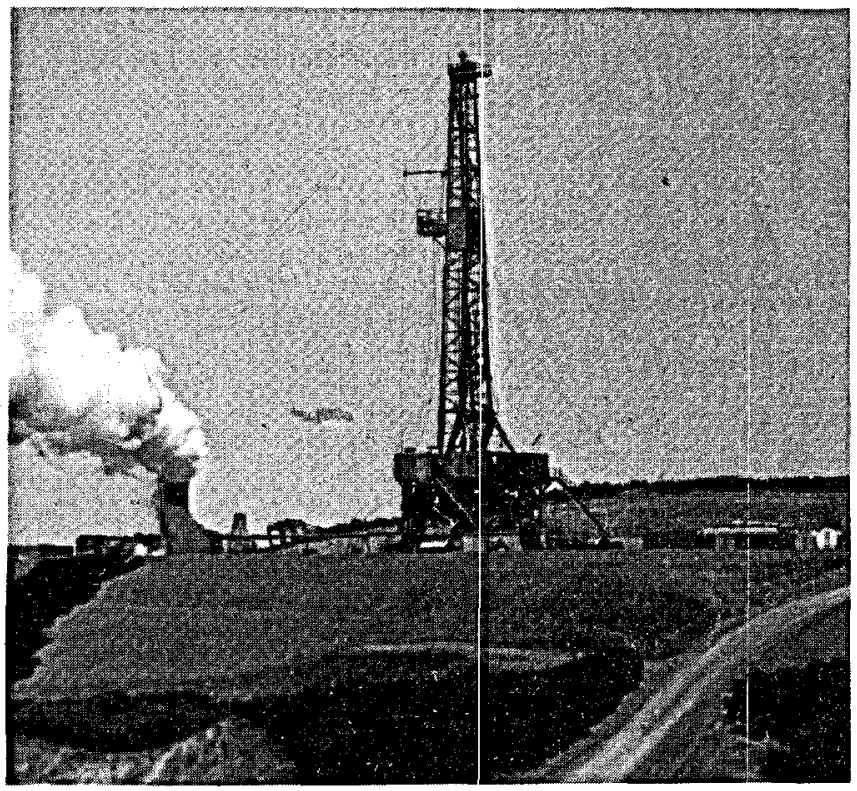

Photo 4. Well Union "DX State 4596" 59, being drilled with air at The Geysers Geothermal field. Air is pumped into the well bore from the compressors, photo right. Returning air, steam (if any), and cuttings from the well bore are piped through a blooie line, to the left of the rig, where the $\mathrm{H}_{2} \mathrm{~S}$ is removed.

Air, steam, and cuttings continue to the muffler-separator cylinder, photo left, where the cuttings are removed and the air and steam are vented. Photo by Ken Stelling. are applied to every well, it is also important to note that each well is unique and needs individual supervision and engineering.

Conventional, oilfield, clay-based drilling fluid (mud) is the circulating fluid used for drilling the upper parts of well bores at The Geysers. Once the well bores have been drilled past water entries and the last serpentinite body or melange, the circulating fluid is changed to air (Photo 4). Air drilling not only allows low pressure steam to enter the well bore, but also increases the drilling rate by as much as five times over mud drilling. The increase occurs because the lost circulation problems associated with the mud method are avoided.

\section{LOGGING}

The numbers and kinds of logging tools used in The Geysers Geothermal field depend upon the policy of the company, and state and federal requirements. In the past, many types of logging devices have been used in exploratory and development wells: mud, temperature, caliper, cement bond, sonic, dual induction, gamma ray, compensated neutron, and compensated density logs. Today, the trend is to run mud, temperature, caliper, dual induction, and cement bond logs. To locate fresh waters, the dual induction $\log$ is usually run on the upper $610 \mathrm{~m}(2,000$ feet) of the first well drilled on a new drilling pad.

Mud logs provide a daily lithologic description of drill cuttings returned to the surface during well drilling operations. The logs include data such as well temperature, pressure, drill rate, bulk rock density, carbon dioxide, hydrogen sulphide, and hole fluid gain or loss. In addition, a mud-logging unit can measure significant steam entries and record the flow rate and enthalpy (Cochran, 1979; Rehm and Goins, 1978)^. Mud logs are used to determine drilling program alternatives as new hole conditions arise, to correlate major stratigraphic rock units in the field, and to make reservoir engineering and geologic evaluations of the steam resource (Cochran, 1979).

\section{CEMENTING}

Cementing techniques have changed greatly over the years at The Geysers Geothermal field. Motivated by ce-

${ }^{A}$ Bibliographical data for references in this chapter are in the Drilling Techrology section of the list of Selected References at the end of the report. 


\section{Casing and Cementing}

$91.44 \mathrm{~cm}\left(36^{\prime \prime}\right)$ hole to $15 \mathrm{~m}\left(50^{\prime} \pm\right)$ $76.2 \mathrm{~cm}\left(30^{\prime \prime}\right) \mathrm{H}-40$ or lapweld

$66.04 \mathrm{~cm}\left(26^{\prime \prime}\right)$ hole to $78 \mathrm{~m}\left(255^{\prime} \pm\right)$; $50.8 \mathrm{~cm}\left(20^{\circ}\right), 114.58 \mathrm{~kg} / \mathrm{m}$ (94 lb.), K-55, C@76m $\left(250^{\prime} \pm\right)$

$17 \mathrm{~m}^{3}$ ( $600 \mathrm{ft}^{3}$ ) "Class G cem., $40 \%$

silica flour and $3 \%$ gel.

$44.45 \mathrm{~cm}\left(17 / \mathrm{c}^{\prime \prime}\right)$ hole to $459 \mathrm{~m}\left(1505^{\prime} \pm\right)$; $27.31 \mathrm{~cm}\left(10 \mathrm{3}^{\circ}\right), 60.26 \mathrm{~kg} / \mathrm{m}$ (40 lb.), K-55 landed, from surface to $396 \mathrm{~m}\left(1300^{\prime} \pm\right)$ and cem. with $17 \mathrm{~m}^{3}$ (600 ft. ${ }^{3}$ ) Class G cem., $40 \%$

silica flour and $3 \%$ gel and $0.5 \%$ CFR-2.*

$33.97 \mathrm{~cm}(133 / 8 "), 81.1 \mathrm{~kg} / \mathrm{m},(61 \mathrm{lb}),. K-55 \mathrm{C} @$ $457 \mathrm{~m}\left(1500^{\prime} \pm\right)$

Preflush; $56.6 \mathrm{~m}^{3}\left(2,000 \mathrm{ft}^{3}\right)$ Class $\mathrm{G}$ cem. 1:1 perlite, $40 \%$ silica flour, $3 \%$ gel, $0.5 \%$ CFR-2, plus $8.5 \mathrm{~m}^{3}$ (300 $\mathrm{ft}^{3}$ ) $\mathrm{Clar}_{3} \mathrm{G}$ cem., $40 \%$ silica flour and $0.5 \%$ CFR-2."

\section{$31.12 \mathrm{~cm}\left(12 \mathrm{H}^{\prime \prime}\right)$ hole to $1525 \mathrm{~m}\left(5005^{\prime} \pm\right)$}

$24.45 \mathrm{~cm}\left(95 / \mathrm{g}^{\prime \prime}\right), 53.57 \mathrm{~kg} / \mathrm{m}$ ( $40 \mathrm{lb}$.) , K-55 hung and cem. from $396 \mathrm{~m}\left(1300^{\prime}\right)$ to $1524 \mathrm{~m}\left(5000^{\prime} \pm\right)$; Preflush; $42.5 \mathrm{~m}^{3}$ (1500 $\mathrm{ft}^{3}$ ) Class $\mathrm{G}$ cem. 1:1 perlite, $40 \%$ silica flour, $3 \%$ gel. $0.5 \%$ CFR-2 ${ }^{\bullet}$ and $0.4 \%$ HR-7.*

$22.23 \mathrm{~cm}(83 / 4 ")$ hole to total depth.
Stratigraphic

Columin

(Base of Groundwater)
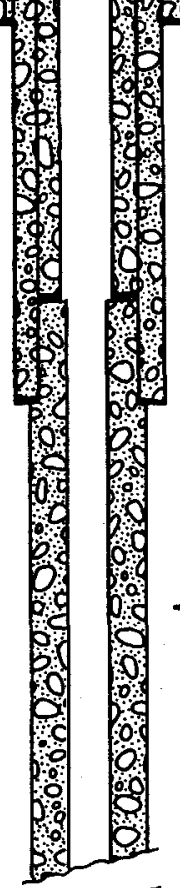

:

9

Greenstone

Melange

Serpentinite

Argillite

Graywacke

8

Top of Steam Reservoir

Drill and survey a $22.23 \mathrm{~cm}\left(83 / 4^{\prime \prime}\right)$ hole with air to total depth. Log all steam entries. Kill well with water. Set drillable bridge plug inside 24.4 (9 5/8") casing. Test lap and squeeze with cement if necessary.

Drill a $31.12 \mathrm{~cm}\left(121 /{ }^{*}\right)$ directional ** hole with mud to $1525 \mathrm{~m}\left(5005^{\prime} \pm\right)$. Plug with cement any lost circulation zones encountered.

Once past any water entries or below the serpentinite, blow hole dry and drill with air to total depth. Survey directional hole.

Condition mud thoroughly and run and cement $24.45 \mathrm{~cm}\left(9 \mathrm{5} \mathrm{8}^{\prime \prime}\right)$ casing from $396 \mathrm{~m}\left(1300^{\prime} \pm\right)$ to $1524 \mathrm{~m}\left(5000^{\prime} \pm\right)$. Use centralizers on casing. Hang casing $2 \mathrm{~m}\left(6^{\prime} \pm\right)$ off bottom and allow a $61 \mathrm{~m}$ $\left(200^{\prime} \pm\right.$ ) overlap with the $33.97 \mathrm{~cm}\left(13 \mathrm{3} / \mathrm{s}^{\prime \prime}\right)$ casing. Drill out any cement at the lap and pressure test the lap. Squeeze with cement, if necessary. Reinstall and test the $33.97 \mathrm{~cm}\left(13 \% \%^{\prime \prime}\right)$ BOPE prior to drilling out the shoe of the $24.45 \mathrm{~cm}(95 \%$ ") casing.

Run and cement a $27.3 \mathrm{~cm}\left(103 \%^{\prime \prime}\right)$ casing tie-back string from $396 \mathrm{~m}\left(1300^{\prime} \pm\right)$ to the surface. Install and test the $27.31 \mathrm{~cm}\left(10^{3} / 4^{\prime \prime}\right)$ casing head assembly. Test the BOPE. Remove bridge plug and clean out hole to total depth. Blow hole dry in stages. Test well and put on "bleed".

Fractured Main Graywacke

*CFR-2-cement friction reducer and low water loss additive.

**HR-7-a retarder.

*** Currently, all wells drilled at The Geysers Geothermal field are directional wells. These specifications would apply to any well in the field.

Figure 27. Generalized casing, cementing, and drilling program. 
menting-casing failures in some geothermal wells, geothermal operators have sought knowledge and skills to prevent further occurrences. Multicasing strings are run and cemented in well bores at The Geysers to provide hole and casing integrity for the life of the well and to anchor the blowout prevention equipment.

The outside of the casing is protected by a properly designed cement slurry pumped into the annular space between the hole wall and the casing. The cement sheath formed in the annular space must be at least $3.8 \mathrm{~cm}\left(1 \frac{1}{2}\right.$ in. $)$ thick. Casing centralizers are used to prevent well eccentricity and cement channeling.

The primary factors affecting a good cement job are heat, zones of lost circulation, and hole geometry. Also necessary are a properly conditioned well bore and drilling mud, an adequate density differential between the mud and cement slurry, and no free water in the cement slurry. A sitting time of $\mathbf{1 8}$ to $\mathbf{2 4}$ hours is required to obtain adequate cement hardness. Without these conditions, a poor cement job will result (Rehm and Goins 1978).

Once casing-setting depth is reached and all hole problems (such as cementing off lost circulation zones) are mitigated, the hole is circulated clean and the drilling mud conditioned. Then, the first casing string is run and cemented to the surface (Fig. 27). The cement slurry used by most operators contains Class $\mathrm{G}$ cement mixed 1:1 with perlite, plus 40 percent silica flour, 0.5 percent retarder, and 3 percent gel.

Normally, Class G cement can only be used where hole temperatures do not exceed $77^{\circ} \mathrm{C}\left(170^{\circ} \mathrm{F}\right)$; but with additives (such as perlite, silica flour, a retarder, and gel), Class $G$ can be used where temperatures reach $300^{\circ} \mathrm{C}$ $\left(600^{\circ} \mathrm{F}\right)$. Perlite lightens the weight of the cement slurry, prevents lost circulation, and provides better fill-up. Silica flour improves cement resistance to heat by preventing a decrease of the cement's compressive strength through time. A retarder provides thinning action and slows cement hardening. Gel ensures good bonding and removes free water from the cement slurry.

Free water in cement behind the casing of producing wells can rupture the casing. This occurs when the casing, heated by the flowing steam, heats the free water trapped between the casing and the cement, thereby causing thermal expansion and possible casing rupture. For example, a temperature increase of $0.5^{\circ} \mathrm{C}\left(1^{\circ} \mathrm{F}\right)$ 'can cause a pressure increase of 3.45 bars ( $50 \mathrm{psi}$ ). Theoretically, if the temperature of the free water was increased by $111^{\circ} \mathrm{C}\left(200^{\circ} \mathrm{F}\right)$, a pressure increase of 689.5 bars $(10,000$ psi) could occur.

\section{COMPLETION}

Once the operator determines that the flow from the $22.23 \mathrm{~cm}(83 / 4$ in.) well bore can be produced commercially, drilling is stopped and the well is flow-tested. The flow rate, pressure, and temperature are measured by placing 3 or 4 sizes of orifice plates in the blooie line (a pipe from the preventor stack to the muffler/separator) while the well blows through the muffler. After testing, the production valve is closed; however, a small amount of steam is generally allowed to escape from the well to prevent steam from condensing inside the well bore. Such condensation would kill the well. When well testing is completed, the drilling rig is disassembled and moved off the site.

\section{INJECTION}

Injection wells are usually converted, subcommercial production wells. However, instead of the $103 / 4$ in. casing tie-back string normally used in production wells, an injection well generally has a $21.59 \mathrm{~cm}$ ( 7 in.), K-55, 38.69 $\mathrm{kg} / \mathrm{m}(26 \mathrm{lb}$./ft.) slotted liner hung at the bottom of the well to prevent the hole from sloughing in and cutting off any open fractures.

The California Division of Oil and Gas (CDOG) requires operators to make periodic downhole surveys of all injection wells. The surveys are run as diagnostic tools to ascertain whether or not the injection fluid is confined to the intended injection zone and if the casing integrity remains intact.

All injection projects must be reviewed and approved by the CDOG before injection operations begin. Once the operations are underway, CDOG engineers witness periodic surveys performed on the wells to assure their continuing mechanical integrity. 
54 


\section{SELECTED REFERENCES}

\section{The Geysers Geothermal Field}

Allen, G.W. and McCluer, H.K., 1975, Abatement of hydrogen sulfide emissions from The Geysers geothermal power plant: U.N. Symposium on the Development and Utilization of Geothermal Resources, San Francisco, California, p. 1313-1315.

Garrison, L.E., 1972, Geothermal steam in The Geysers - Clear Lake Region, California: Geological Society of America Bulletin 83, p. 1449.

McMillan, D.A., Jr., 1970, Economics of The Geysers Geothermal field, California: U.N. Symp. on the Development and Utilization of Geothermal Resources, Pisa, Italy, v. 2, pt. 2, p. 1705, or Geothermics Spec. Issue 2.

\section{Subsurface Geology}

Allen, E.T. and Day, A.L., 1927, Steam wells and other thermal activity at "The Geysers", California: Carnegie Inst. Washington Publication no. 378, $106 \mathrm{p}$.

Atwater, Tanya, 1970, Implications of plate tectonics for the Cenozoic tectonic evolution of western North America: Geological Society of America Bulletin, v. 81, p. 3513-3536.

Badgley, P.C., 1959, American Institute of Mining and Metalurgical Engineering, preprint no. 59169.

Bailey, E.H., 1946, Quicksilver deposits of the western Mayacamas district, Sonoma County, California: California Journal of Mines and Geology, v. 42, p. 199-230.

Bailey, E.H., Blake, M.C., Jr., and Jones, D.L., 1970, On-Land Mesozoic oceanic crust in the California Coast Ranges: U.S. Geological Survey Professional Paper 700c, p. c70-c81.

Blake, M.C., Jr., Irwin, W.P., and Coleman, R.G., 1967, Upside-down metamorphic zonation, blue schist facies, along a regional thrust in California and Oregon, in Geological Research 1967: U.S. Geological Survey Professional Paper 575c, p. c1-c9.

Blake, M.C., Jr., and Jones, D.L., 1974, Origin of Franciscan melanges in Northern California: Society of Economic Paleontologists and Mineralogists Special Publication 19, p. 345-357.

Bufe, C.G., 1980, Seismicity of The Geysers - Clear Lake region, California: U.S. Geological Survey Open-File Report 80-988, 21 p.

Capuano, L.E., Ir., 1979, How Geysers steam wells are drilled and equipped: World Oil, v. 188, no. 2, p. 69-72.

Crowell, J.C., 1974, Origin of Late Cenozoic basins in Southern California, in Tectonics and sedimentation: Society Economic Paleontologists and Mineralogists Special Publication 22, p. 190-204.

D'Amore, F., Truesdell, A.H., 1979, Models for steam chemistry at Larderello and The Geysers in Proceedings Fifth Workshop Geothermal Reservoir Engineering: December 11-14, 1979, p. 283-297.

Dickinson, W.R., 1970, Clastic sedimentary sequences deposited in shelf, slope, and trough settings between magmatic area and associated trenches: Pacific Geology, v. 3, p. 15-30.

Donnelly, J.M., 1977, Geochronology and evolution of the Clear Lake volcanic field: Ph.D. Thesis, University of California, Berkeley, $48 \mathrm{p}$. 
Donnelly, J.M., Hearn, B.C., Jr., and Goff, F.E., 1977, The Clear Lake Volcanics, California: Geology and field trip guide, in Field Trip guide to The Geysers-Clear Lake area for the Cordilleran section of the Geological Society of America: April 1977, p. 25-56.

Donnelly, J.M., McLaughlin, R.J., Goff, R.E., and Hearn, B.C., Jr., 1976, Active faulting in The Geysers-Clear Lake area, Northern California: Geological Society of America Abstracts with Programs, v. 8, no. 3, p. 369-370.

Goff, F.E., Donnelly, J.M., and Thompson, J.M., 1977, Geothermal prospecting in The GeysersClear Lake area, Northern California: Geology, v. 5, p. 509-515.

Goff, F.E., and McLaughlin, R.J., 1976, Geology of the Cobb Mountain-Ford Flat Geothermal area, Lake County, California: U.S. Geological Survey Open-File map 76-221, 1 sheet $(1: 24,000)$, explanation and sections.

Goff, F.E., 1981, Los Alamos Laboratory: written and oral communication.

Harding, T.P., 1973, Newport-Inglewood trend, California - an example of wrenching style of deformation: American Association of Petroleum Geologists Bulletin, v. 57, p. 97-116.

Hearn, B.C., Jr., Donnelly, J.M., and Goff, F.E., 1976a, Preliminary geologic map and crosssection of the Clear Lake Volcanic field, Lake County, California: U.S. Geological Survey Open-File Report 76-751.

Hearn, B.C., Ir., Donnelly, J.M., and Goff, F.E., 1976b, Geology and geochronology of the Clear Lake Volcanics, California in Proceedings of the Second U.N. Symp. on the Development and Use of Geothermal Resources, 20-29 May, 1975: San Francisco, California, 1975, v. 1, p. 423-428.

Hearn, B.C., Jr., Donnelly, J.M., and Goff, F.E., 1978, Continental-edge volcanism at Clear Lake, California: hot spot, leaky transform, or heated oceanic slab?: Geological Society of America Abstracts with Programs, v. 10, no. 7, 418 p.

Hearn, B.C., Jr., Donnelly-Nolan, J.M., and Goff, F.E., 1981, The Clear Lake volcanics: tectonic setting and magma sources in McLaughlin, R.J.,Donnelly-Nolan, J.M., eds., Research in The Geysers-Clear Lake area, Northern California: U.S. Geol: Survey Prof. Paper 1141, p. 25-45 .

Hsu, K.J., 1968, Principles of melanges and their bearing on the Franciscan-Knoxville paradox: Geological Society of America Bulletin, v. 79, no. 8, p. 1063-1074.

Jamieson, I.M., 1976, Heat flow in a geothermally active area: The Geysers, California: Ph.D thesis, University of California, Riverside, California, $143 \mathrm{p}$.

Lambert, S.J., 1976, Stable isotope studies of some active geothermal systems: Ph.D thesis, California Institute of Technology, $387 \mathrm{p}$.

Lipman, S.C., Strobel, C.J., and Gulati, M.S., 1978, Reservoir performance of The Geysers field, in Proceedings of the Larderello workshop on geothermal resource assessment and reservoir engineering, Sept. 12-16, 1977, Pisa, Italy: Geothermics, v. 7, p. 209-219.

Magma Power Co., 1979: Annual report, p. 5.

McLaughlin, R.J., 1977, Late Mesozoic-Quaternary plate tectonics and The Geysers-Clear Lake geothermal anomaly, northern Coast Ranges, California: Geological Society of America Abstracts with Programs, v. 9, no. 4, 464 p.

McLaughlin, R.J., 1977, The Franciscan Assemblage and Great Valley sequence in The GeysersClear Lake region of Northern California, in Field trip guide to The Geysers-Clear Lake area for the Cordilleran Section of the Geological Society of America: April 1977, p. 3-24.

McLaughlin, R.J., 1978, Preliminary geologic map and structural sections of the central Mayacamas Mtns. and The Geysers steam field, Sonoma, Lake, Mendocino Counties: U.S. Geological Survey Open-File Report no. 78-389, 2 sheets, 1 map $(1: 24,000)$, and explanation and cross sections.

McLaughlin, R.J., 1980, Written communication.

McLaughlin, R.J., 1981, Tectonic setting of pre-Tertiary rocks and its relation to geothermal resources in The Geysers-Clear Lake area in McLaughlin, R.J., and Donnelly-Nolan, J.M., eds., Research in The Geysers-Clear Lake area, Northern California: U.S. Geol. Survey Prof. Paper 1141, p. 3-23.

McLaughlin, R.J., and Pessagno, E.A., 1978, Significance of age relations above and below Upper Jurassic ophiolite in The Geysers-Clear Lake region, California: U.S. Geological Survey Journal of Research, v. 6, p. 715-726.

McLaughlin, R.J., and Stanley, W.D., 1976, Pre-Tertiary geology and structural control of geothermal resources, The Geysers steam field, California, U.S.A., in Proceedings Second U.N. Symp. on the Development and Use of Geothermal Resources: San Francisco, California, May 1975, v. 1, p. 475-485.

MCNitt, J.R., 1963, Exploration and development of geothermal power in California: California Division of Mines and Geology, Special Report 75, 45 p. 
McNitt, J.R., 1968, Geology of the Kelseyville quadrangle, Sonoma, Lake, and Mendocino Counties, California: California Division of Mines and Geology, map sheet 8.

Sacramento Municipal Utility District, 1980, Evaluation of the potential for generation of electricity: Geothermal Lease CA-1862, Sonoma and Lake Counties, proprietary report.

Schriener, A., Jr., and Suemnicht, G.A., 1980, Subsurface intrusive rocks at The Geysers Geothermal area, California: Geological Society of America, Abstracts with Programs, v. 12, no. 3, p. 152.

Swe, Win, and Dickinson, W.R., 1970, Sedimentation and thrusting of Late Mesozoic rocks in the Coast Ranges near Clear Lake, California: Geological Society of America Bulletin, v. 81, no. 1, p. 165-189.

Sylvester, A.G., and Smith, R.R., 1976, Tectonic transpression and basement-controlled deformation in San Andreas fault zone, Salton Trough, California: American Association of Petroleum Geologists Bulletin, v. 66, no. 12, p. 2081-2102.

White, D.E., Muffler, L.J.P., and Truesdell, A.H., 1971, Vapor-dominated hydrothermal systems compared with hot water systems: Economic Geology, v. 66, no. 1, p. 75-97.

Wilcox, R.E., Harding, T.P., and Seely, D.R., 1973, Basic wrench tectonics: American Association of Petroleum Geologists Bulletin, v. 57, p. 74-96.

\section{Geophysics}

Blake, M.C., Jr., Irwin, W.P., and Coleman, R.G., 1967, Upside-down metamorphic zonation, blue schist facies, along a regional thrust in California and Oregon, in Geological Research 1967: U.S. Geological Survey Professional Paper 575C, p. C1-C9.

Bufe, C.G., and others, 1980, Seismicity of The Geysers - Clear Lake region, California: U.S. Geol. Survey Open-File Report 80-988, 21 p.

Chapman, R.H., 1966, Gravity map of The Geysers area, California: California Division of Mines and Geology, Mineral Information Service, v. 19, p. 148-149.

Chapman, R.H., 1975, Geophysical study of the Clear Lake region, California: California Division of Mines and Geology, Special Report 116, 23 p.

Chapman, R.H., 1978, Gravity anomalies in The Geysers - Clear Lake area, Northern California: Field Trip guidebook 45, Castle Steam Field, Great Valley Sequence, 53rd Annual meeting Pacific Section American Association of Petroleum Geologists, Society of Economic Paleontologists and Mineralogists, and Society of Exploration Geophysicists, Sacramento, California, April 26-29, 1978, p. 89-98.

Chapman, R.H., and Bishop, C.C., 1974, Bouguer gravity map of California, Santa Rosa Sheet: California Division of Mines and Geology, map and $7 \mathrm{p}$. text, scale 1:250,000.

Chapman, R.H., and others, 1975, Bouguer gravity map of California, Ukiah Sheet: California Division of Mines and Geology, map and 6 p. text, scale 1:250,000.

Denlinger, R.P., 1979, Geophysics of The Geysers Geothermal field, Northern California: Ph.D. thesis, Stanford University, Stanford, California, 87 p.

Denlinger, R.P., Isherwood, W.F., and Kovach, R.L., 1979, An analysis of gravity and geodetic changes due to reservoir depletion at The Geysers, Northern California: Geothermal Resources Council Transactions, v. 3, p. 153-156.

Denlinger, R.P., and Kovach, R.L., 1981, Seismic-reflection investigations at Castle Rock Springs in The Geysers Geothermal area, in McLaughlin, R.J., and Donnelly-Nolan, J.M., eds., Research in The Geysers-Clear Lake area, Northern California: U.S. Geol. Survey Prof. Paper 1141 p. $117-128$.

Goff, F.E., Donnelly, J.M., and Thompson, J.M., 1977, Geothermal prospecting in The GeysersClear Lake area, Northern California: Geology, v. 5, p. 509-515.

Griscom, Andrew, 1973, Gravity map of California, Redding Sheet: California Division of Mines and Geology, map and 13 p. text, scale 1:250,000.

Hamilton, R.M., and Muffler, L.J.P., 1972, Microearthquakes at The Geysers Geothermal area, California: Journal of Geophysical Research, v. 77, no. 11, 2081-2086.

Isherwood, W.F., 1975, Gravity and magnetic studies of The Geysers-Clear Lake geothermal region, California: U.S. Geol. Survey Open-File Report 75-368, 37 p.

Isherwood, W.F., 1976a, Complete Bouguer gravity map of The Geysers area, California: U.S. Geol. Survey Open-File Report 76-357, scale 1:62,500.

Isherwood, W.F., 1976b, Residual gravity map of The Geysers area, California: U.S. Geol. Survey Open-File Report 76-356, scale 1:62,500. 
Isherwood, W.F., 1976c, Gravity and magnetic studies of The Geysers-Clear Lake geothermal region, California, U.S.A., in Proceedings, Second U. N. Symp. on the Development and Use of Geothermal Resources: San Francisco, California, 1975, v. 2, p. 1065-1073.

Isherwood, W.F., 1977, Geothermal reservoir interpretation from changes in gravity: Proceedings, Third Workshop for Geothermal Reservoir Engineering, Stanford, California, p. 18-23.

Isherwood, W.F., 1981, Geophysical overview of The Geysers, in McLaughlin, R.J., and Donnelly-Nolan, J.M., eds. Research in The Geysers-Clear Lake area, Northern California: U.S. Geol. Survey, Prof. Paper 1141, p. 83-95.

Isherwood, W.F., and Chapman, R.H., 1975, Principal facts for gravity stations in The GeysersClear Lake region, California: U.S. Geol. Survey Open-File Report 75-106, 15 p.

lyer, H.M., Oppenheimer, D.H., and Hitchcock, Tim, 1979, Abnormal P-wave delays in The Geysers-Clear Lake geothermal area, California: Science, v. 204, p. 495-497.

Jamieson, I.M, 1976, Heat flow in a geothermally active area: The Geysers, California: Ph.D. thesis, University of California, Riverside, California, $143 \mathrm{p}$.

Jennings, C.W., and Strand, R.G., 1960, Geologic map of California, Olaf P. Jenkins edition, Ukiah Sheet: California Division of Mines and Geology, scale 1:250,000.

Koenig, J.B., 1963, Geologic map of California, Olaf P. Jenkins edition, Santa Rosa Sheet: California Division of Mines and Geology, scale 1:250,000.

Lange, A.L., and Westphal, W.H., 1969, Microearthquakes near The Geysers, Sonoma County, California: Journal of Geophysical Research, v. 74, no. 17, p. 4377-4378.

Lofgren, B.E., 1981, Monitoring crustal deformation in The Geysers-Clear Lake region, in McLaughlin, R.J., and Donnelly-Nolan, J.M., eds. Research in The Geysers-Clear Lake area, Northern California: U.S. Geol. Survey Prof. Paper 1141, p. 139-148.

Long, C.L., and Senterfit, R.M., 1976, Audio-magnetotelluric station location map, The GeysersCalistoga Known Geothermal Resource Area, California: U.S. Geol. Survey Open-File Report 76-700D, 3 p.

Ludwin, R.S., and Bufe, C.G., 1980, Continued seismic monitoring of The Geysers, California, geothermal area: U.S. Geol. Survey Open-File Report 80-1060, 50 p.

Majer, E.L., and McEvilly, T.V., 1979, Seismological investigations at The Geysers Geothermal field: Geophysics, v. 44, no. 2, p 246-269.

Marks, S.M., and others, 1978, Seismic monitoring of The Geysers Geothermal field, California: U.S. Geol. Survey Open-File Report 78-798, 26 p.

McLaughlin, R.J., 1978, Preliminary geologic map and structural sections of the central Mayacamas Mountains and The Geysers steam field, Sonoma, Lake and Mendocino Counties, California: U.S. Geol. Survey Open-File Report 78-389, scale 1:24,000.

McLaughlin, R.J., and Stanley, W.D., 1976, Pre-Tertiary geology and structural control of geothermal resources, The Geysers steam field, California, U.S.A., Proceedings, Second U. N. Symp. on the Development and Use of Geothermal Resources: San Francisco, California, 1975 , v. 1, p. $475-485$.

Olson, J.J., and Warburton, R.J., 1979, Continuous gravity observations at The Geysers: a preliminary report: Geothermal Resources Council Transactions, v. 3, p. 519-522.

Schriener, Alexander, Jr., and Suemnicht, G.A., 1980, Subsurface intrusive rocks at The Geysers geothermal area, California: Geological Society of America, Abstracts with Programs, v. 12, no. 3, p. 152.

Smith, J.L., Isselhardt, C.F., and Matlick, J.S., 1978, Summary of 1977 geothermal drilling Western United States: Geothermal Energy, v. 6, no. 5, p. 11-19.

Stanley, W.D., Jackson, D.B., and Hearn, B.C., Jr., 1973, Preliminary results of geoelectrical investigations near Clear Lake, California: U.S. Geol. Survey Open-File Report, 20 p.

U.S. Geological Survey, 1973, Aeromagnetic map of the Clear Lake area, Lake, Sonoma, Napa, and Mendocino Counties, California: U.S. Geol. Survey Open-File Report 73-299, scale $1: 62,500$.

Urban, T.C., and others, 1976, Heat flow at The Geysers, California, U.S.A., in Proceedings, Second U. N. Symp. on the Development and Use of Geothermal Resources: San Francisco, California, 1975, v. 2, p. 1241-1245.

Warren, D.H., 1981, Seismic-refraction measurements of crustal structure near Santa Rosa and Ukiah, California, in McLaughlin, R.J., and Donnelly Nolan, J.M., eds. Research in The Geysers-Clear Lake area, Northern California: U.S. Geol. Survey, Prof. Paper 1141 p. 167181. 


\section{Reservoir Assessment}

Allen, E.T. and Day, A.L., 1927, Steam wells and other thermal activity at "The Geysers", California: Carnegie Inst. Washington Publ. No. 378, 106 p.

Allen, G.W., and McCluer, H.K., 1976, Abatement of hydrogen sulfide emissions from The Geysers geothermal power plant, in Proceedings, Second U.N. Symp. on the Development and Use of Geothermal Resources: San Francisco, California, 1975, v. 2, p. 1313-1315.

Budd, C.F., Jr., 1972, Producing geothermal steam at The Geysers field: SPE paper 4178, Bakersfield, Calif. Mtg., Nov. 8-10.

Chasteen, A.J., 1976, Geothermal condensate steam reinjection in Proceedings, Symp. of the Development and Use of Geothermal Resources: San Francisco, Calif., 1975, v. 2, p. 133536.

Decius, L.C., 1961, Geological environment of hyperthermal areas in continental United States and suggested methods for prospecting them for geothermal power: U.N. Conf. on New Sources of Energy, Rome, Paper G48, p. 166-178.

Economides, M.J., and Fehlberg, E.L., 1979, Two short-time buildup test analyses for Shell's Geysers Well D-6, a year apart: Summ. Fifth Workshop Geothermal Reservoir Engineering, Stanford Univ.

Fetkovich, M.J., 1973, Decline curve analysis using type curves: SPE paper 4629 , Las Vegas, Nev., meeting.

Garrison, L.E., 1972, Geothermal steam in The Geysers-Clear Lake Region, California: Geological Society of America Bull. 83, p. 1449.

Lipman, S.C., Strobel, C.J., and Gulati, M.S., 1977, Reservoir performance of The Geysers field in Proceedings of the ENEL-ERDA Workshop: Larderello, Italy, p. 233.

Magma Power Co. Annual Report, year ended Dec. 31, 1979, six months ended June 30, 1980: p. 5.

McNitt, J.R., 1963, Exploration and development of geothermal power in California: California Division of Mines and Geology, Special Report 75, $45 \mathrm{p}$.

McMillan, D.A., Jr., 1970, Economics of The Geysers Geothermal field, California in Proceedings U.N. Symp. on the Development and Utilization of Geothermal Resources: Pisa, Italy, v. 2 pt. 2, p. 1705, or Geothermics Spec. Issue 2 ,

Pacific Gas and Electric Company, 1979, Application for certification of Geysers Unit 18: April 17.

Ramey, H.J., Jr., 1970, Short-time well test data interpretation in the presence of skin effect and wellbore storage: Jour. Pet. Tech. 22, p. 97-104.

Ramey, H.J., Jr., 1970, A reservoir engineering study of The Geysers Geothermal field, Reich and Reich, Petitioners, vs. Commissioner of Internal Revenue: 1969 Tax Court of the United States, 52. T.C. No. 74, 1970.

Ramey, H.J., Jr., 1976, Pressure transient analysis for geothermal wells, in Proceedings, Second U.N. Symp. on the Development and Utilization of Geothermal Resources: San Francisco, v. 3, p. 1749-1757.

Ramey, H.J., Jr., and Gringarten, A.C., 1976, Effect of high volume vertical fractures on geothermal steam well behavior, in Proceedings, Second U.N. Symp. on the Development and Use of Geothermal Resources: San Francisco, Calif., v. 3, p. 1759-1762.

Strobel, C.J., 1976, Field case studies of pressure buildup behavior in Geysers steam wells, in Proceedings Second Workshop Geothermal Reservoir Engineering: Stanford Univ. p. 143149.

Truesdell, A.H., Frye, G.A., and Nathenson, M., 1978, Downhole measurements and fluid chemistry of a Castle Rock steam well, The Geysers, Lake County, California, in Proceedings Fourth Workshop Geothermal Reservoir Engineering: Stanford Univ. p. 96-105.

Whiting, R.L., and Ramey, H.J., Jr., 1969, Application of material and energy balances to geothermal steam production: Jour. Pet. Tech. 21 (7), p. 893-900. 


\section{Drilling Technology}

Budd, C.F., 1973, Producing geothermal steam at The Geysers field: Society of Petroleum Engineers paper 4178.

Campbell, G.E., 1975, Geothermal well drilling and completion practices in California including casing and abandonment programs and examples of blowouts, unpublished report: California Division of Oil and Gas, $31 \mathrm{p}$.

Capuano, L.E., Jr., 1979, How Geysers steam wells are drilled and equipped: World Oil, v. 188, no. 2, p. 69-72.

Cochran, L.E., 1979, Formation evaluation in the geothermal environment, The Geysers steam field, California: Society of Petroleum Engineers paper 8452.

Cromley, T., 1973, Geothermal drilling in California: Society of Petroleum Engineers paper 4177.

Friedman, E.J., and El-Sawy, A., 1977, Prospects for improvements in geothermal well technology and their expected benefits, DGE/4014-4MTR-7613: Metrek Division, The Metre Corp.

Glass, W.A., 1977, 1977 drilling methods and costs at The Geysers: Geothermal Resources Council Trans., v. 1, p. 103-105.

Kruger, P., and Otte, C., 1973, Geothermal energy, resources production, stimulation: Stanford University Press, $360 \mathrm{p}$.

Lipman, S.C., Strobel, C.J., and Gulati, M.G., 1978, Reservoir performance of The Geysers field: Geothermics, v. 7, p. 209-219.

Maurer, W.C., 1976, Geothermal drilling technology, in Proceedings of the Second U.N. Symp. on the Development and Use of Geothermal Resources, 20-29 May, 1975: v. 2, p. 1509-1521.

Petroleum Information Corporation, 1979, The geothermal resource, earth's natural heat providing energy now: Petroleum Information Corporation, p. 199.

Raschen, R., and Cook, W.S., 1976, Exploration and development of geothermal resources: U.S. Geological Survey, $29 \mathrm{p}$.

Reed, M.J., and Campbell, G.E., 1976, Environmental impact of development in The Geysers Geothermal field, U.S.A., in Proceedings of the Second U.N. Symp. on the Development and Use of Geothermal Resources, May 20-29, 1975, v. 2, p. 1399-1410.

Rehm, W.A., and Goins, W.C., Jr., 1978, Geothermal blowout control, phase I study of existing technology: U.S. Department of Energy, D.G.E., EG-76-C-07-1603, Model No. A003.

Shryock, S.H., and Smith, D.K., 1981, Geothermal cementing - the state of the art, in Proceedings of the First International Conference on Geothermal Drilling and Completion Technology: Albuquerque, New Mexico, January 1981.

Walters, D., 1981, Verbal communication. 


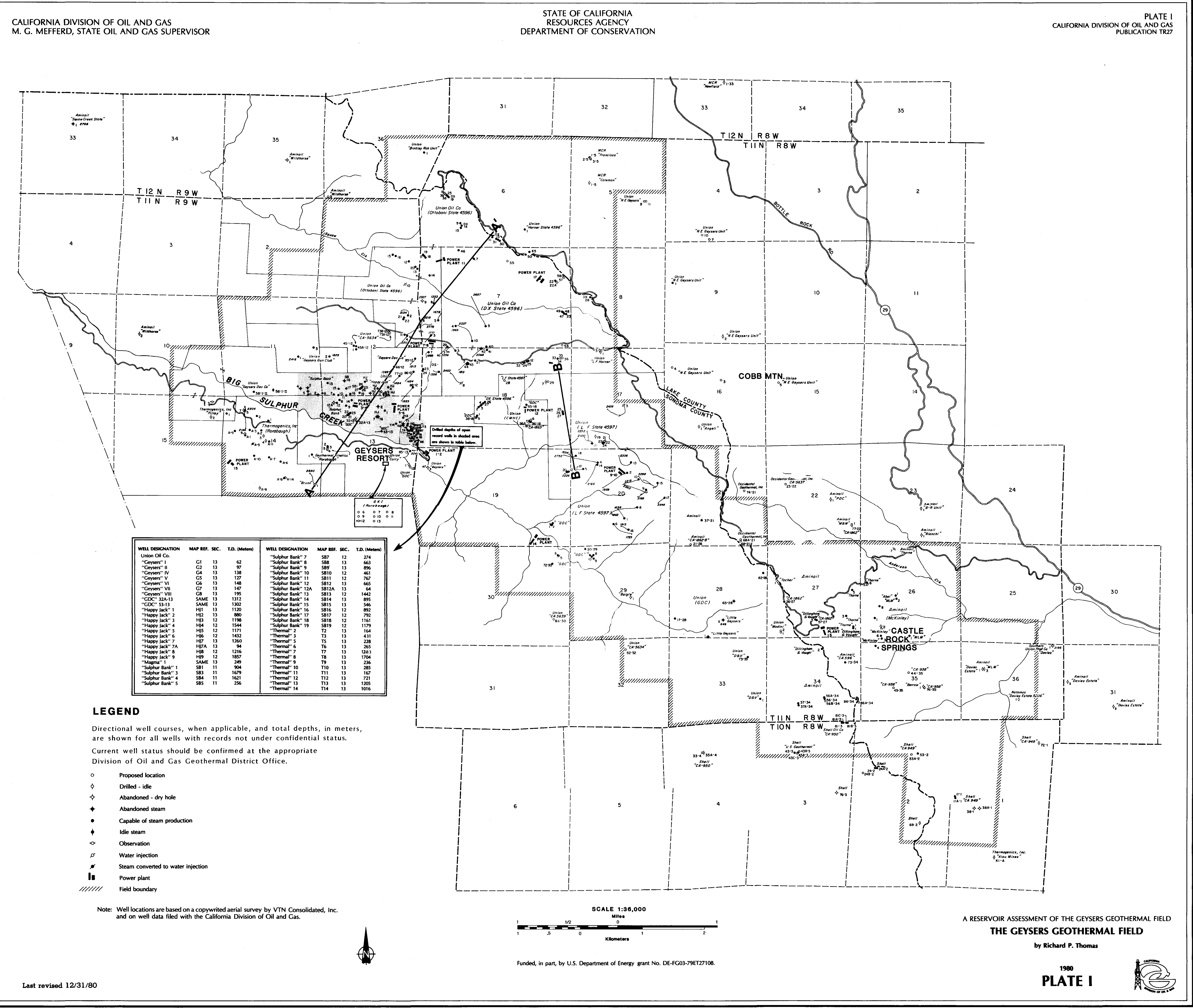



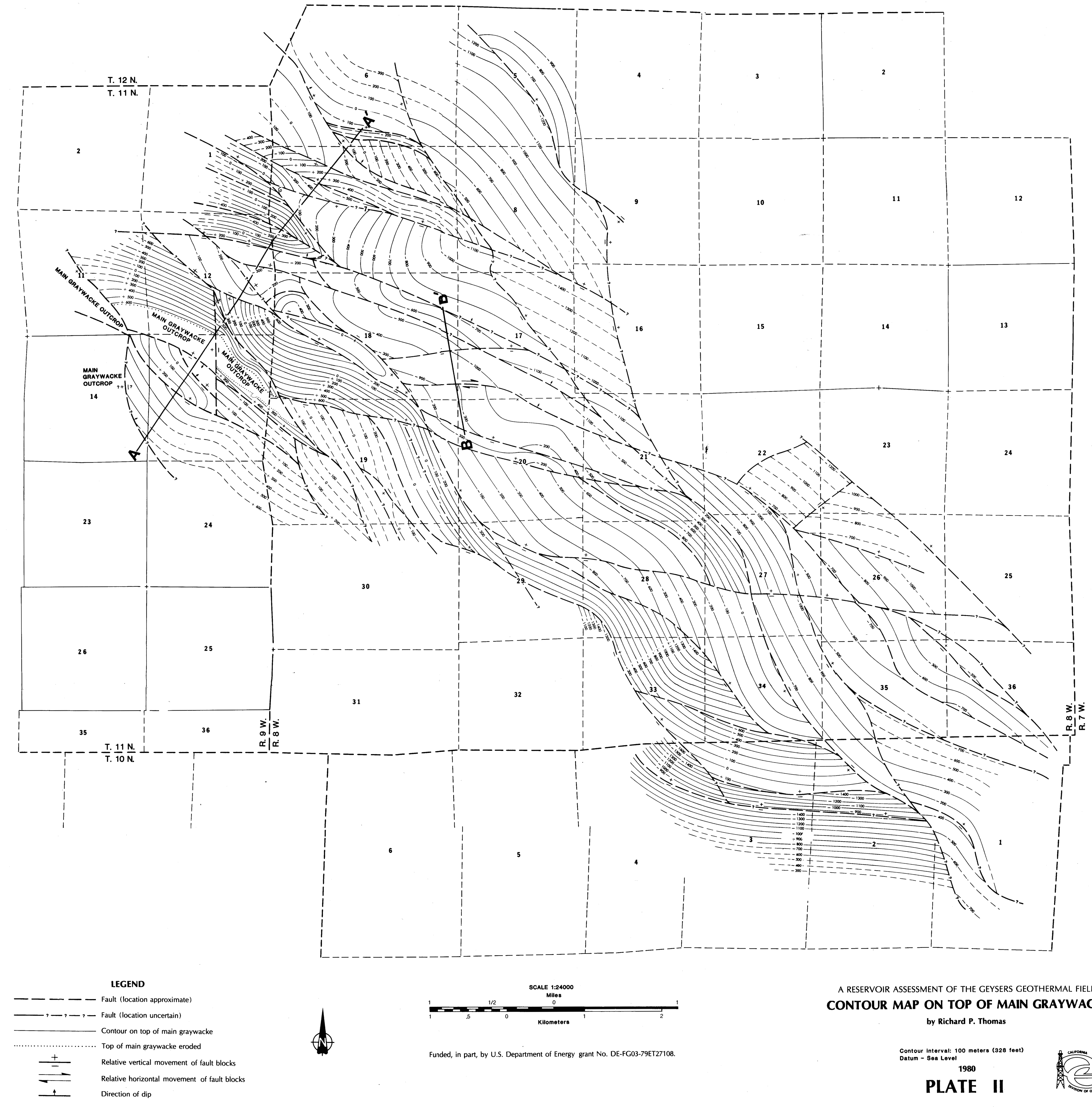

A RESERVOIR ASSESSMENT OF THE GEYSERS GEOTHERMAL FIELD CONTOUR MAP ON TOP OF MAIN GRAYWACKE by Richard P. Thomas 


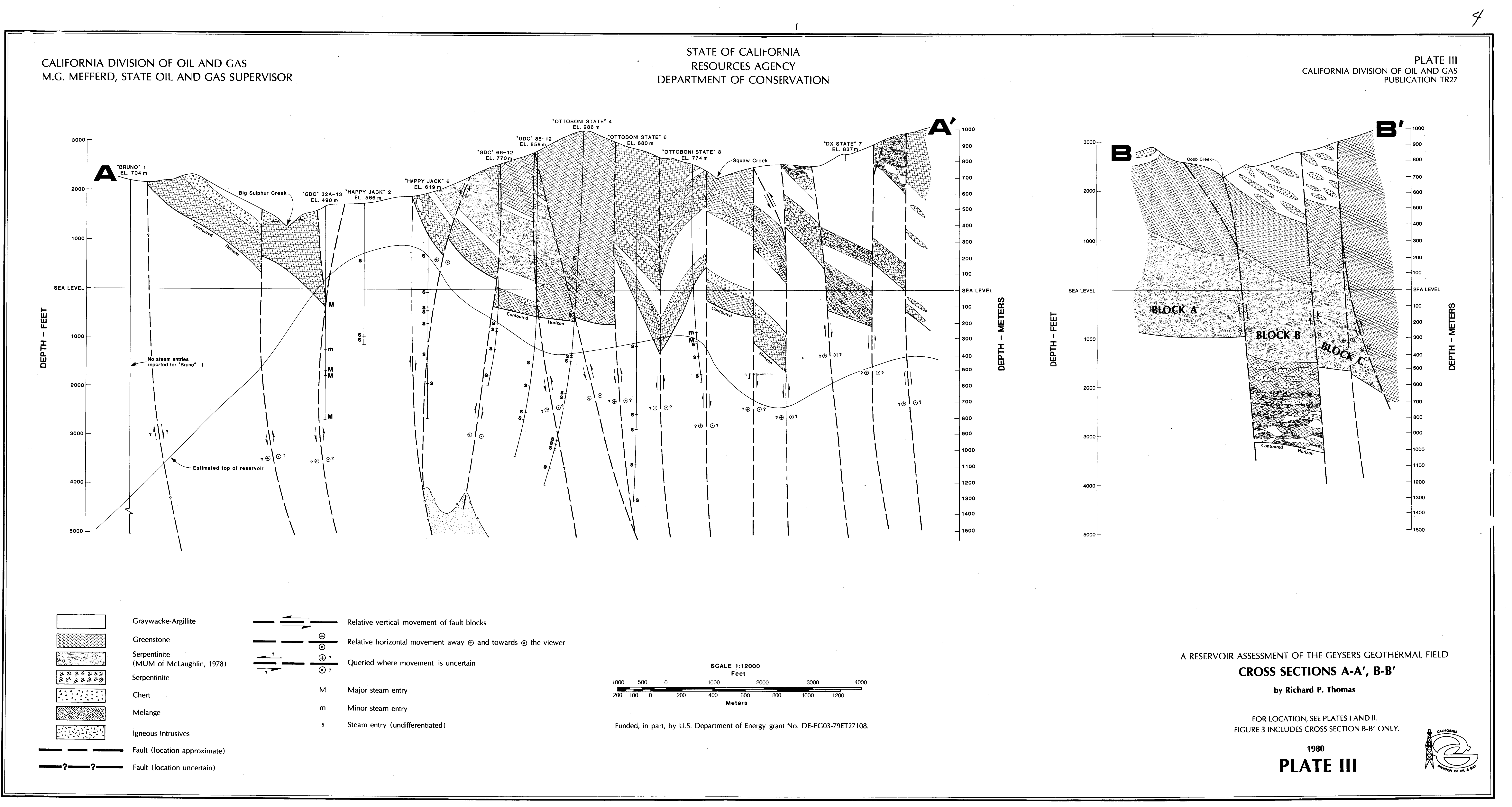




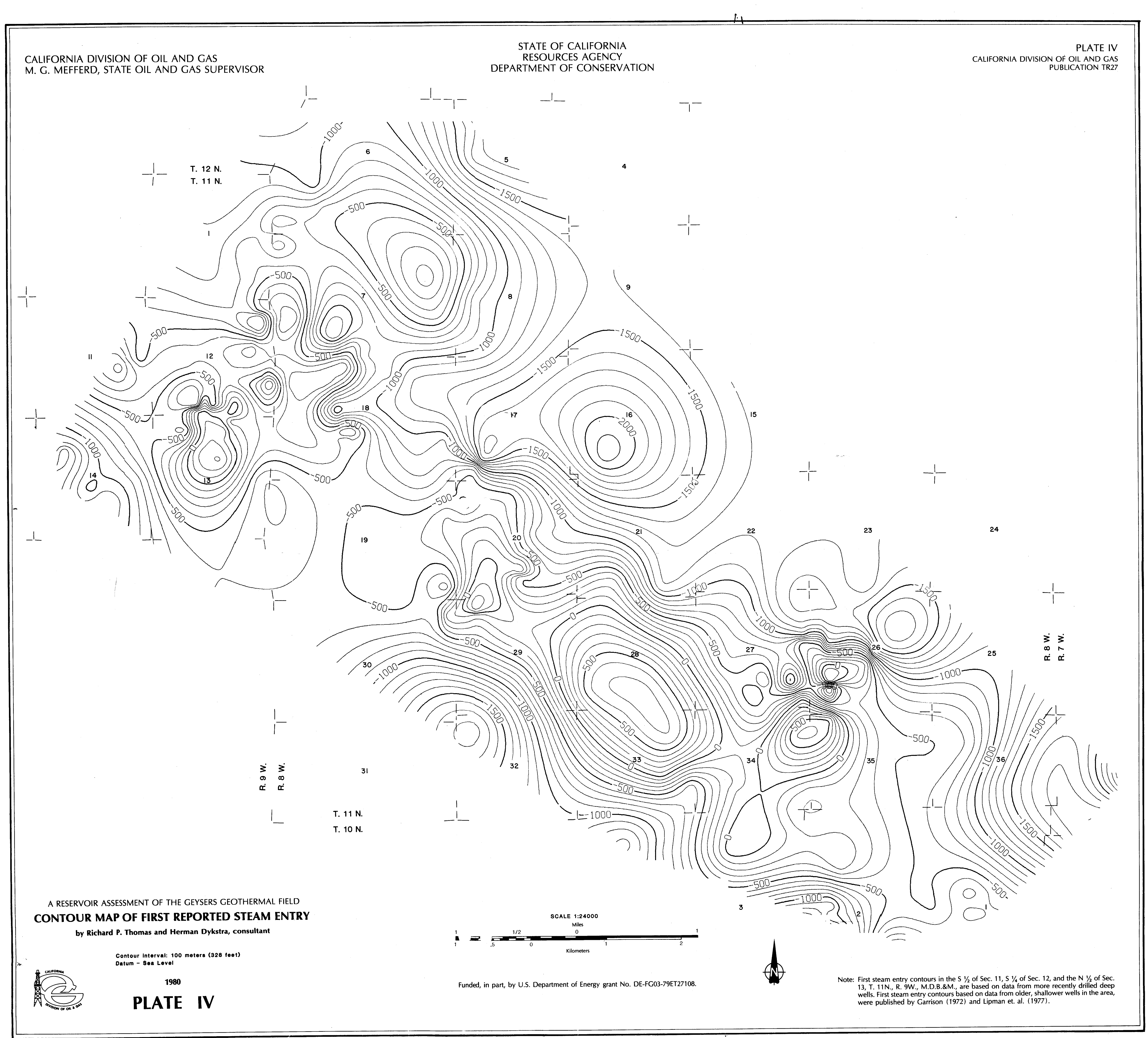

CNTOUR MAP OF FIRST REPORTED STEAM ENTRY

$$
\begin{aligned}
& \text { Contour Interval: } 100 \text { meters (328 toet) } \\
& \text { Datum - 8ea Lovel }
\end{aligned}
$$

PLATE IV 


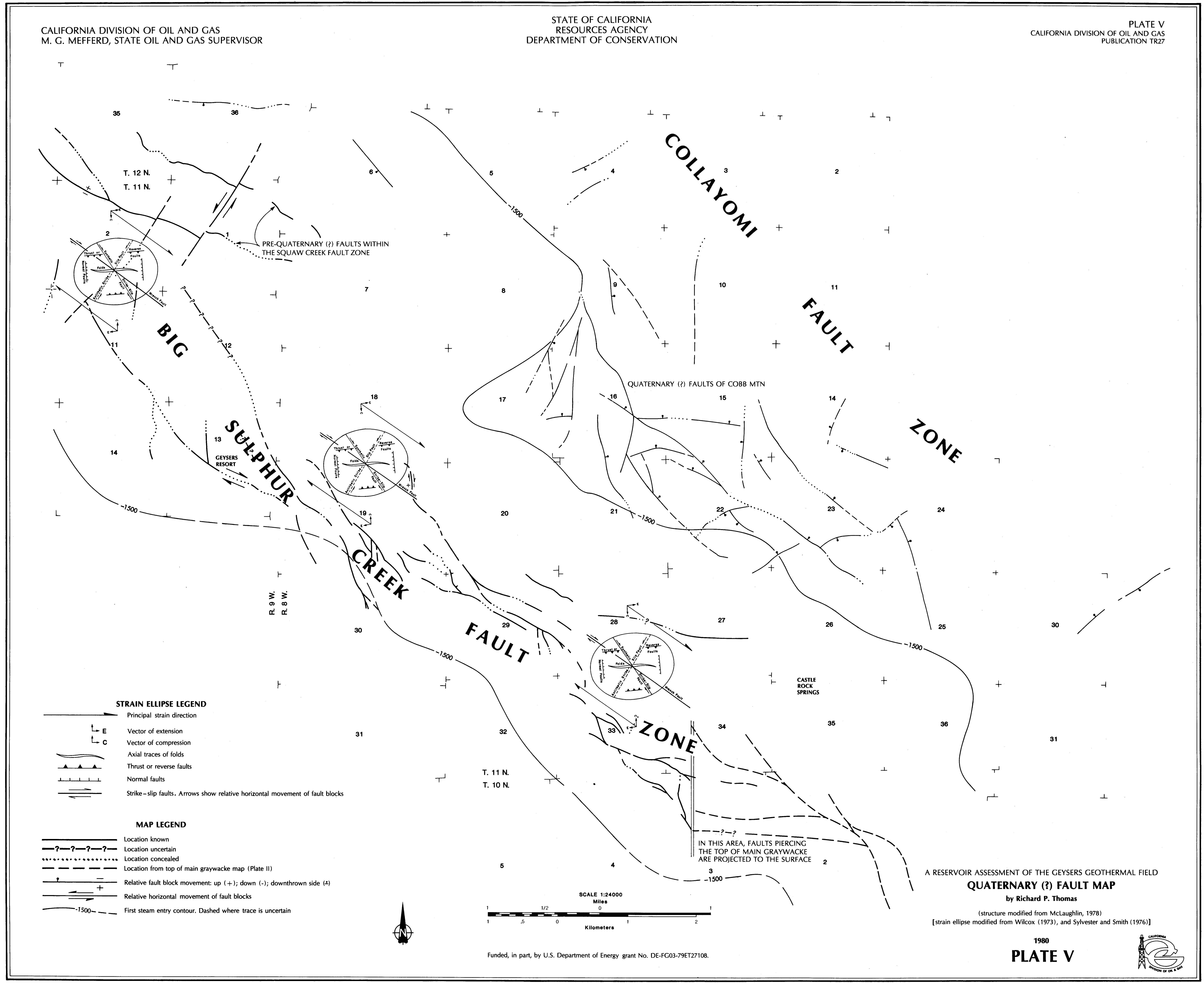




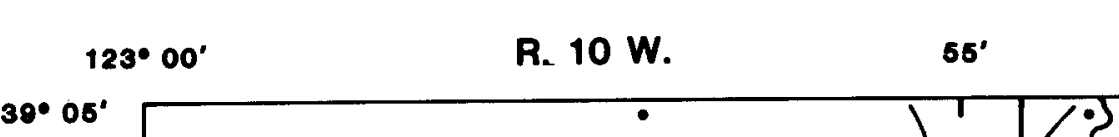

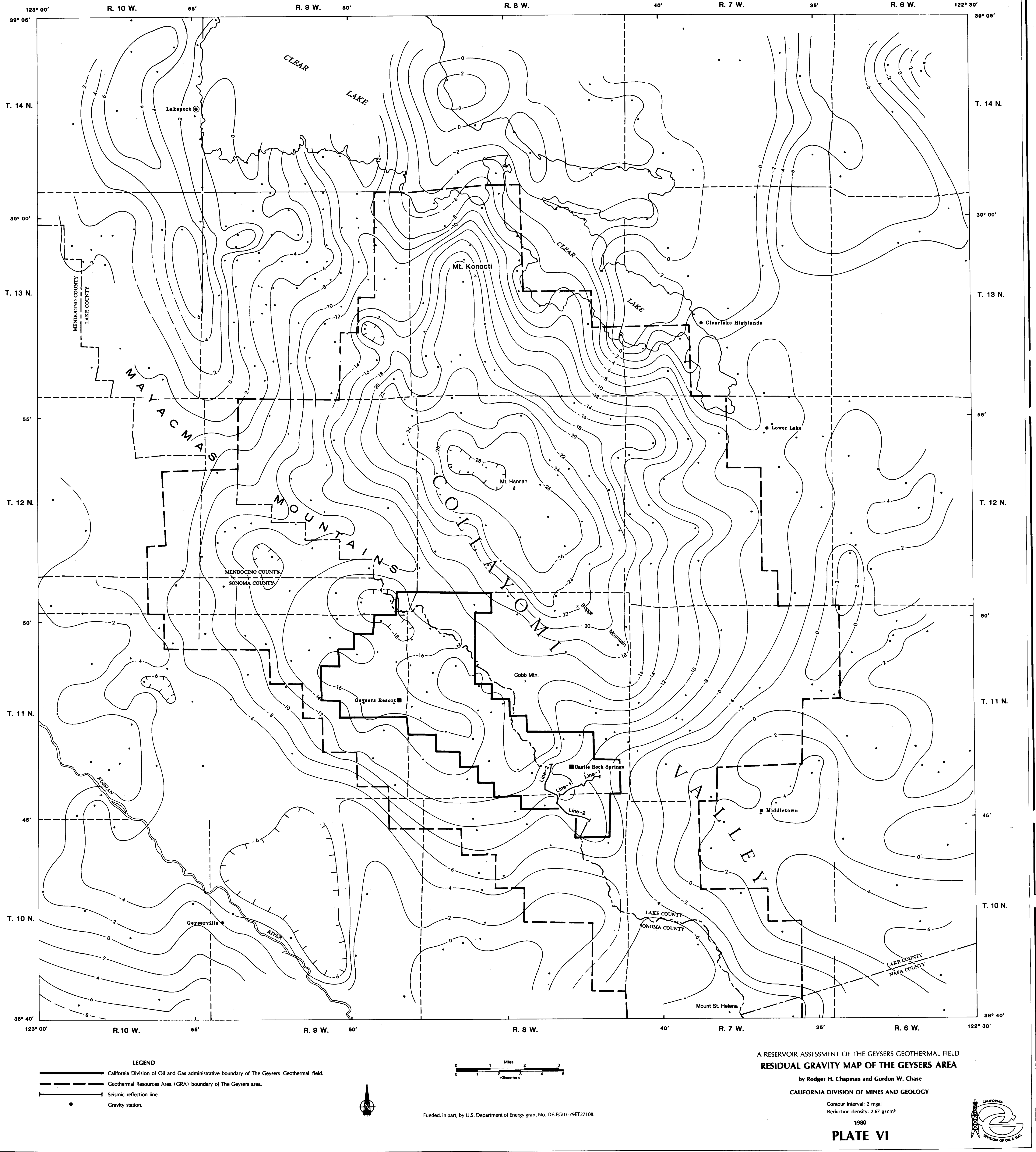

R. 8 W. 
R. $10 \mathrm{~W}$.

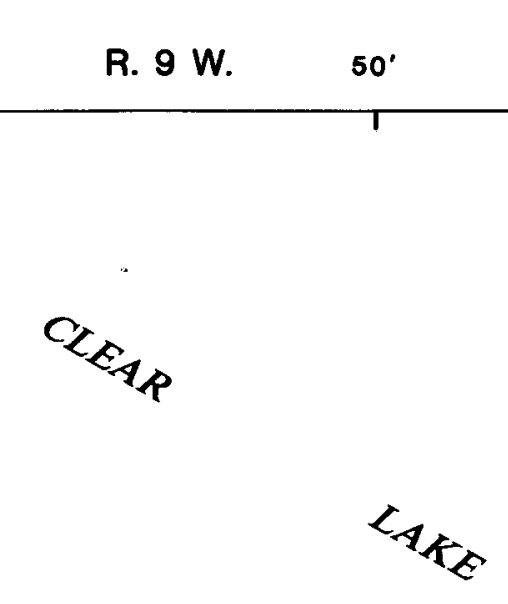

R. 8 W.
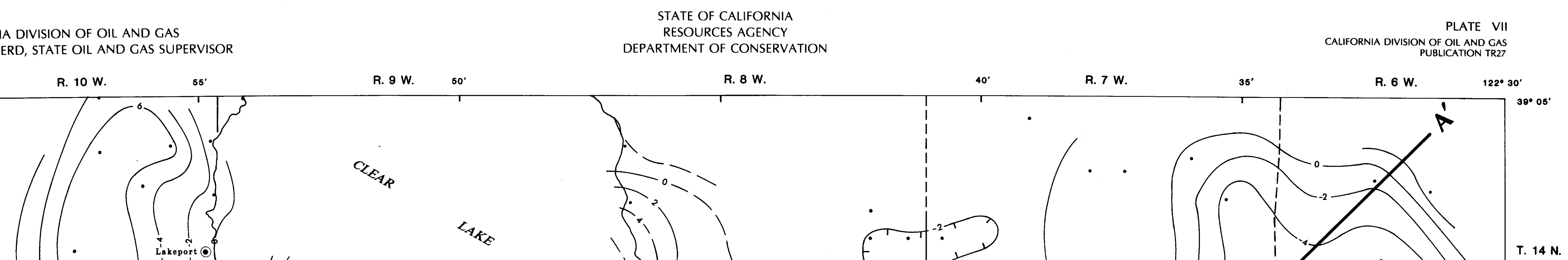

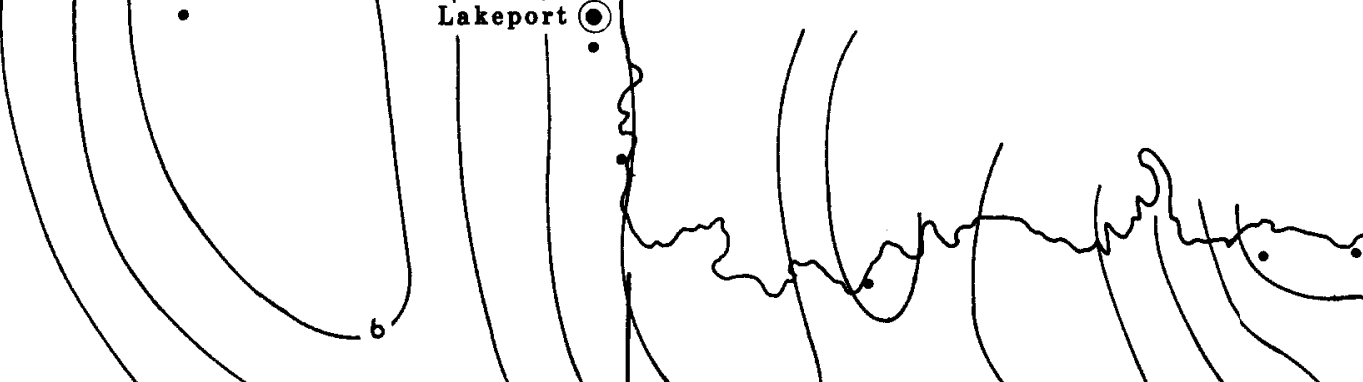
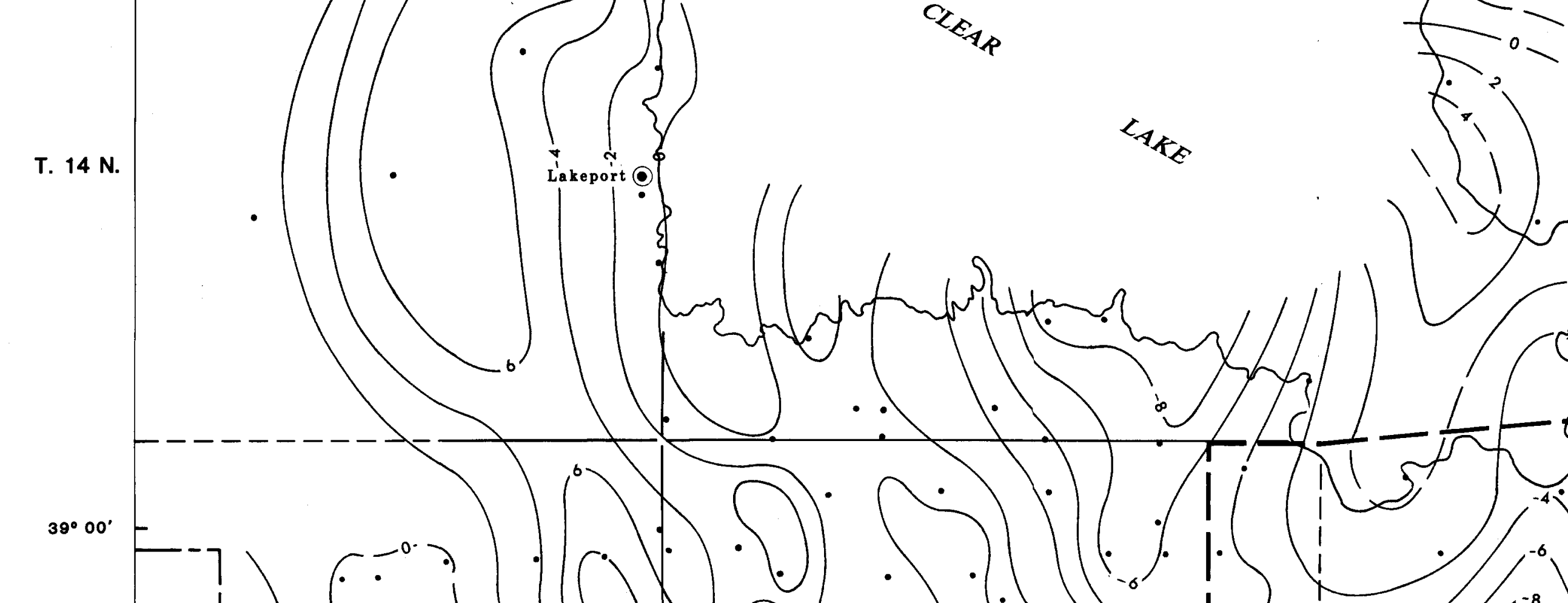

W

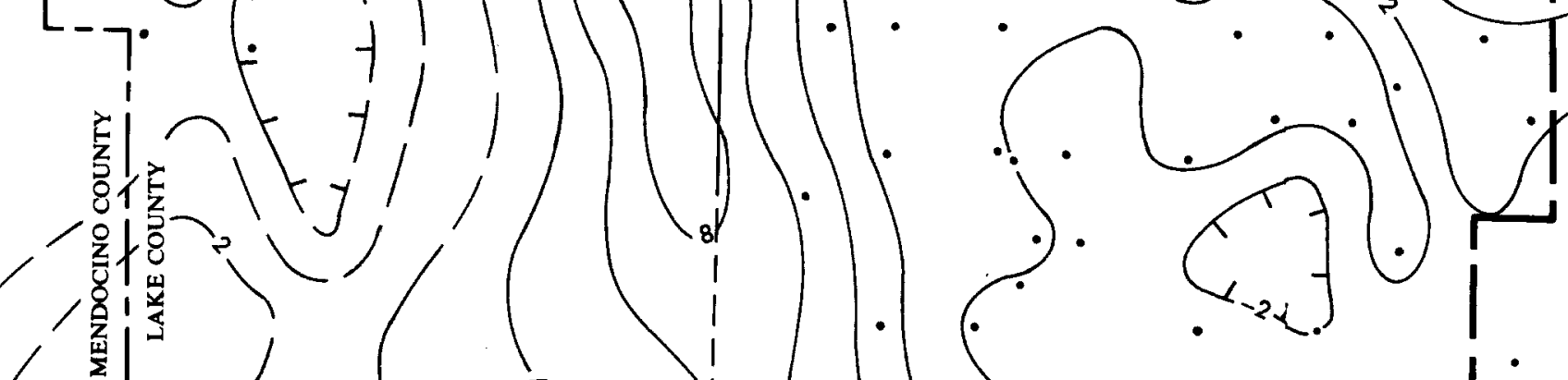

T. $13 \mathrm{~N}$.

$1 / 1 / 1$
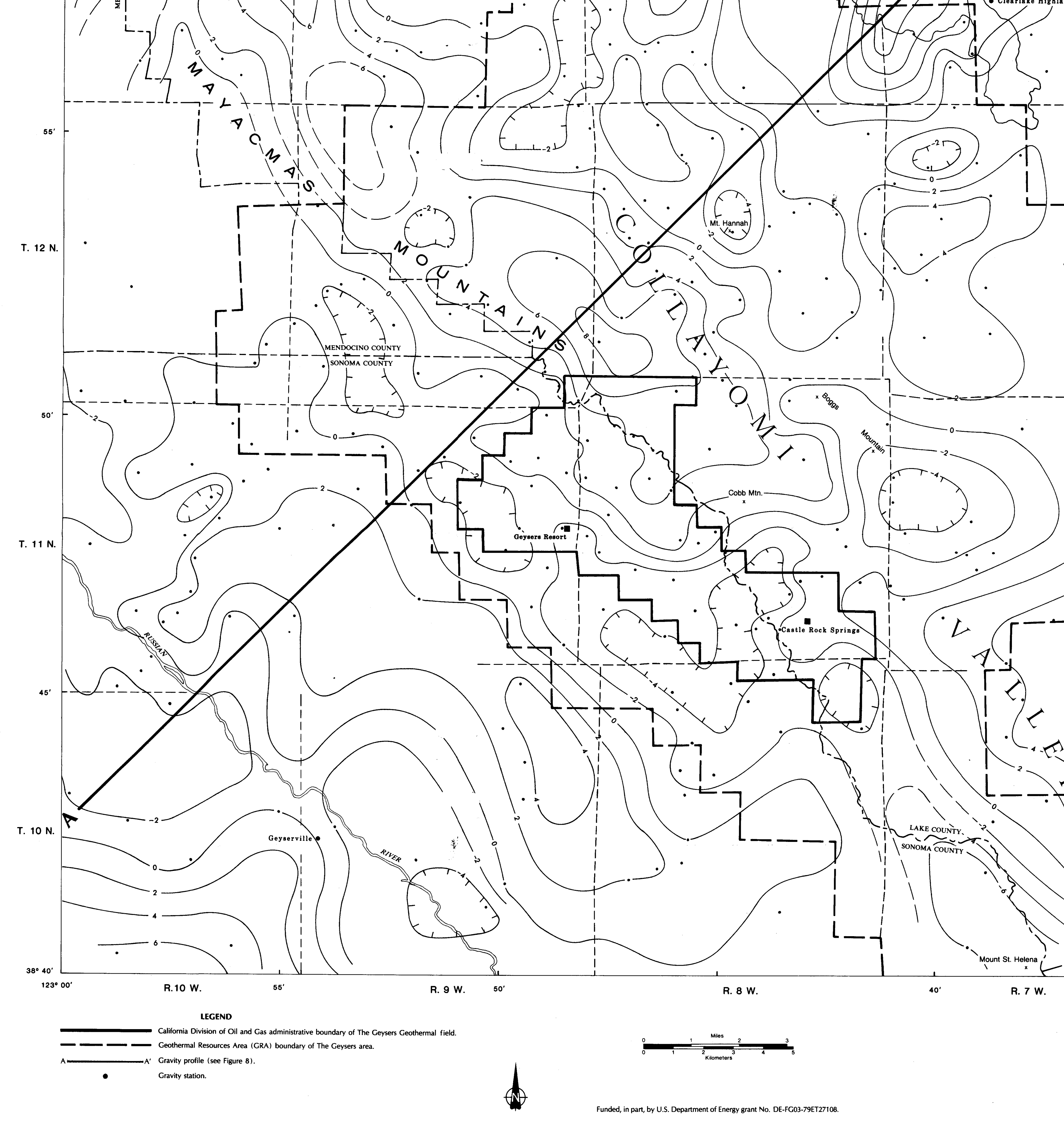


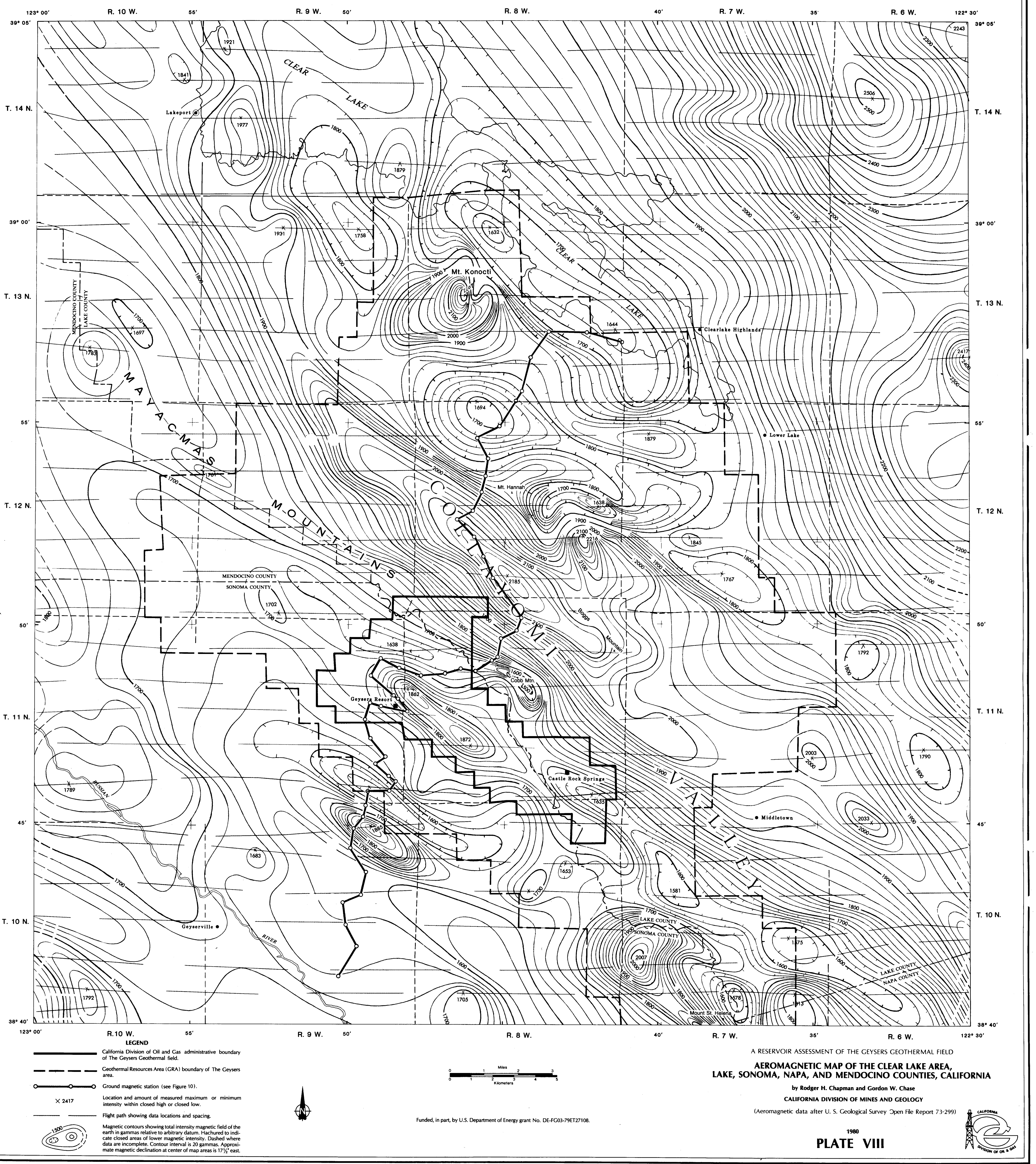


